UNIVERSIDADE DE SÃO PAULO

FACULDADE DE ECONOMIA, ADMINISTRAÇÃO E CONTABILIDADE DE RIBEIRÃO PRETO

DEPARTAMENTO DE ADMINISTRAÇÃO

\title{
VALIDAÇAO DA ESCALA DE PSM - PUBLIC SERVICE \\ MOTIVATION POR MEIO DE MODELAGEM DE EQUAÇOES \\ ESTRUTURAIS
}

CAROLINA LASMAR BUIATTI

ORIENTADOR: PROF. Dr. GILBERTO TADEU SHINYASHIKI 


\section{Validação da escala de PSM - Public Service Motivation por meio de modelagem de equações estruturais}

Dissertação a ser apresentada ao Mestrado do Programa de Pós-Graduação em Administração de Organizações do Departamento de Administração da Faculdade de Economia, Administração e Contabilidade de Ribeirão Preto da Universidade de São Paulo.

Ribeirão Preto 


\section{FICHA CATALOGRÁFICA}

Buiatti, Carolina Lasmar

Validação da escala de PSM - Public Service Motivation por meio de modelagem de equações estruturais. Ribeirão Preto, 2007. 156 p. : il. ; $30 \mathrm{~cm}$

Dissertação de Mestrado, apresentada à Faculdade de Economia, Administração e Contabilidade de Ribeirão Preto/USP. Área de concentração: Administração de Organizações.

Orientador: Shinyashiki, Gilberto Tadeu.

1. Motivação. 2. Setor Público. 3. Validação de escala. 


\section{FOLHA DE APROVAÇÃO}

Carolina Lasmar Buiatti

Validação da escala de PSM - Public Service Motivation por meio de modelagem de equações estruturais

Dissertação a ser apresentada ao Mestrado do Programa de Pós-Graduação em Administração de Organizações do Departamento de Administração da Faculdade de Economia, Administração e Contabilidade de Ribeirão Preto da Universidade de São Paulo.

Aprovada em:

Banca examinadora

Prof. Dr.

Instituição: Assinatura:

Prof. Dr.

Instituição: Assinatura:

Prof. Dr.

Instituição: Assinatura: 
À minha família, pelo apoio incondicional em todos os momentos e, principalmente, ao meu pai, minha inspiração de vida. 


\section{AGRADECIMENTOS}

Ao meu orientador, Professor Doutor Gilberto Tadeu Shinyashiki, pelo apoio na realização desta dissertação e pela confiança na minha escolha, quando eu resolvi me aventurar em um tema ainda pouco explorado no Brasil. Os resultados mostraram que foi um esforço válido, uma vez que abriu caminhos para o desenvolvimento de muitas pesquisas futuras.

Ao Professor Doutor Gene A. Brewer, professor do Departamento de Administração e Políticas Públicas da Universidade da Geórgia e membro do conselho editorial da revista Public Administration Review, que gentilmente me recebeu em visita à Universidade da Geórgia e que me deu um apoio fundamental no levantamento de referências e de material sobre o Public Service Motivation (PSM).

A todas as pessoas que me receberam nas Secretarias Municipais de Ribeirão Preto pesquisadas.

Aos meus colegas de turma, Paulão, Claudinha e Akira e às minhas amigas Thaís e Cristiana pelo companheirismo durante todo o período de aulas, no desenvolvimento da dissertação e também nas escapadas para relaxar.

A minha irmã, Patrícia, pelo apoio que sempre me deu e pela coragem que me inspira.

A todas as minhas irmãs de coração, minhas amigas de Uberlândia, que apesar da distância sempre estiveram presentes me estimulando e apoiando.

A minha mãe, Maguida, que mesmo longe, sempre esteve ao meu lado.

Ao meu pai, Walter Buiatti, pela pessoa e professor exemplar que é, e quem me influenciou a me decidir por seguir a carreira de docente e também pela paciência de ler e discutir este trabalho comigo incansavelmente. 
"It always seems impossible until its done"

(Nelson Mandela) 


\section{RESUMO}

\section{BUIATTI, C. L. Validação da escala de PSM - Public Service Motivation por meio de}

modelagem de equações estruturais. 2007. 156 f. Dissertação (Mestrado) - Faculdade de Economia, Administração e Contabilidade de Ribeirão Preto, Ribeirão Preto, 2007.

Os motivos que levavam as pessoas a procurar emprego no setor público, baseavam-se principalmente na busca pela segurança, tanto financeira quanto de carreira, além de outros benefícios. O contexto dos dias atuais está um pouco modificado, uma vez que reformas foram feitas no Estado a fim de promover mudanças na máquina administrativa do governo. Com esse novo modelo de gestão em pauta, o governo iniciou uma reforma do Estado, atuando, entre outras áreas importantes do governo, na área de Recursos Humanos. Assim, o presente estudo é relevante, também, para a literatura que trata do PSM - Public Service Motivation, uma vez que os principais estudos da área se concentram nos EUA, e alguns em desenvolvimento na Bélgica e na Coréia. O objetivo principal deste estudo, portanto, é cumprir as etapas da validação de constructo da escala de medida do PSM - Public Service Motivation para as secretarias pesquisadas no município de Ribeirão Preto. O presente estudo pode ser caracterizado como quantitativo e descritivo, uma vez que utilizará o método survey para a coleta dos dados e identificará e descreverá um fenômeno. A amostra é caracterizada como não-probabilística por acessibilidade e composta por servidores públicos que compõem os quadros funcionais das secretarias municipais pesquisadas. O instrumento de medida será um questionário formado pela escala do PSM - Public Service Motivation, pela escala de comprometimento organizacional de Meyer e Allen, além de dados demográficos. A conclusão foi de que a escala pode ser utilizada, porém necessita de ajustes para melhor adequação de seu uso.

Palavras-chave: motivação, setor público, validação de escala. 


\begin{abstract}
BUIATTI, C. L. Validação da escala de PSM - Public Service Motivation por meio de modelagem de equações estruturais. 2007. 156 f. Dissertação (Mestrado) - Faculdade de Economia, Administração e Contabilidade de Ribeirão Preto, Ribeirão Preto, 2007.

The reasons that used to take people to seek job in the public sector were based, mainly, in the search for stability and financial security, plus the benefits. Nowadays, this context has been modified, once reforms were made in the State in order to promote changes in the government's administrative machine. With that new administration model on the agenda, the government began a State reform that took action, among other important areas of the government, in the area of Human Resources. The study is relevant for the PSM (Public Service Motivation) literature since the main studies are concentrated in the USA, with some few that are under development in Belgium and in Korea. The main objective of this study, therefore, it is to do the steps of the construct validation of the scale of measurement of PSM Public Service Motivation for the municipals agencies researched in Ribeirão Preto. The present study can be characterized as quantitative, descriptive and exploratory, once it will use the survey method for data collection, it will identify and it will describe a phenomenon and will familiarize with this phenomenon, in order to obtain a new perception on the same. The sample is characterized as non-probabilistic for accessibility and it will be composed by public workers from the agencies researched. The measurement instrument will be a questionnaire formed by the Perry's scale of PSM - Public Service Motivation, by Meyer and Allen's scale of organizational commitment, and some demographic data. The conclusion is that the scale can be used, but it's necessary to improve it to use it with more adequacy.
\end{abstract}

Keywords: motivation, public sector, scale validation. 


\section{SUMARIO}

CAPÍTULO 1 - INTRODUÇAO.................................................... 15

1.2. PROBLEMA DE PESQUISA............................................ 21

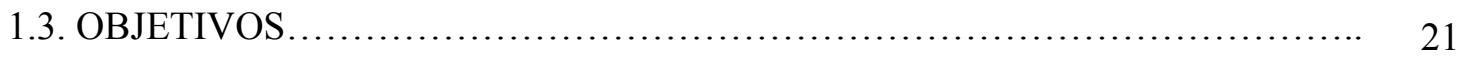

1.3.1. Geral........................................................ 21

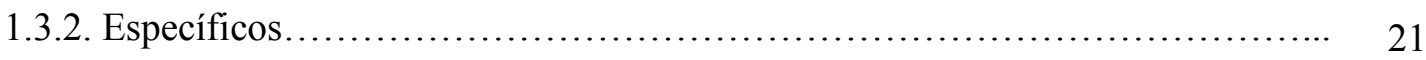

CAPÍTULO 2. REFERENCIAL TEÓRICO......................................... 22

2.1. TEORIAS MOTIVACIONAIS ............................................ 22

2.1.1. Teoria das Necessidades de Maslow...................................... 25

2.1.2. Teoria dos Dois Fatores.............................................. 29

2.1.3. Teoria X e Teoria Y................................................... 31

2.1.4. Tríade Realização-Poder-Afiliação (Teoria ERG)......................... 32

2.1.5. Teoria da Eqüidade............................................... 33

2.1.6. Teoria do Reforço................................................... 34

2.1.7. Teoria do Estabelecimento de Metas.................................. 36

2.1.8. Teoria da Motivação por Impulso....................................... 37

2.1.9. Teoria da Expectativa................................................. 39

2.2. PSM E AS TEORIAS MOTIVACIONAIS ........................................................ 41

2.3. TEORIA DO PSM - PUBLIC SERVICE MOTIVATION .................................. 42

2.3.1. A construção do instrumento de medida de PSM........................... 46

2.3.2. Possíveis fatores antecedentes do PSM.................................. 50

CAPITULO 3 - MOTIVAÇÃO, PSM E COMPROMETIMENTO.................. 54

CAPÍTULO 4 - O SERVIÇO PUBLICO NO BRASIL................................ 57

4.1. O serviço público........................................................ 59

4.2. Emprego Público...................................................... 61

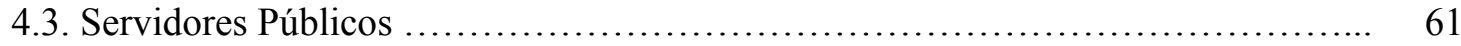

4.4. Cargo, emprego ou função............................................ 62

4.5. Sistemas Remuneratórios................................................ 63

4.6. Aposentadoria........................................................ 63

4.7. Estabilidade e Vitaliciedade............................................ 65

4.8. Direitos e deveres.................................................... 66 
CAPÍTULO 5 - O SERVIÇO PÚBLICO NOS EUA.................................... 68

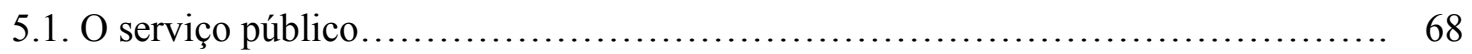

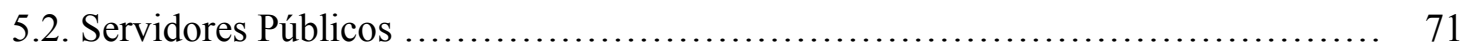

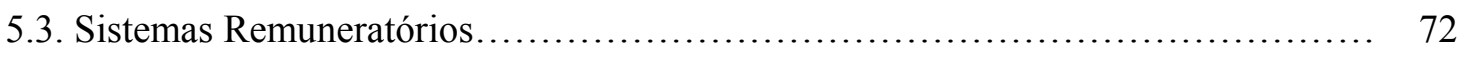

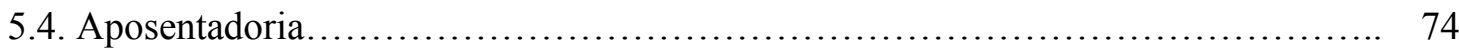

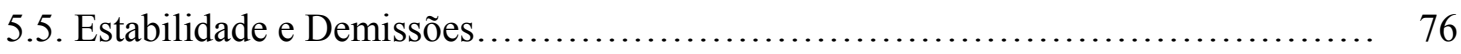

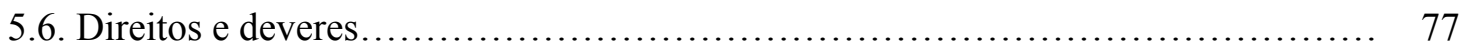

5.7. Considerações sobre os serviços públicos brasileiro e Americano........................... 79

CAPÍTULO 6 - METODOLOGIA DE PESQUISA.................................... 83

6.1. DEFINIÇÃO DE TERMOS E VARIÁVEIS.......................................... 83

6.1.1. Motivação no serviço público..................................................... 84

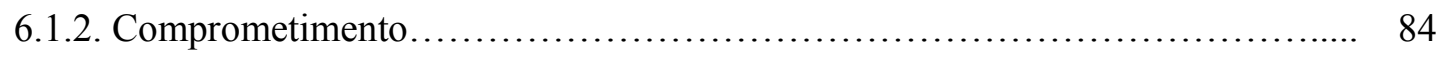

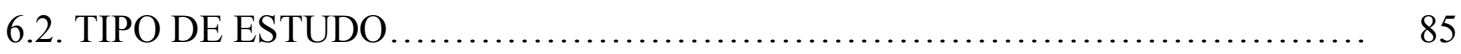

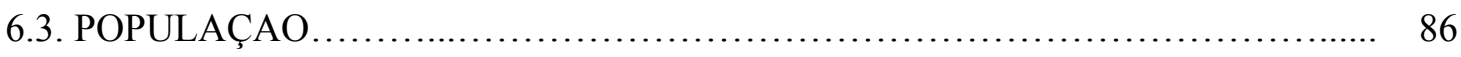

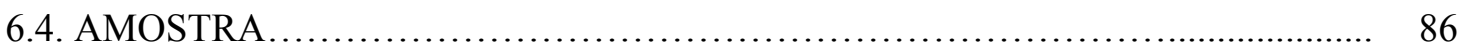

6.5. INSTRUMENTO DE MENSURAÇAO............................................ 88

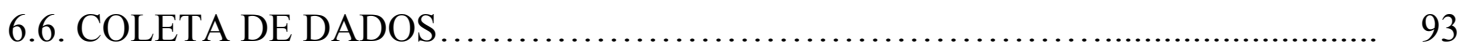

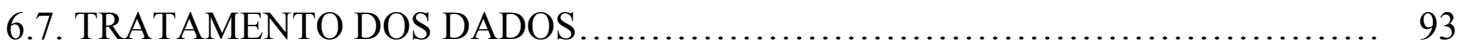

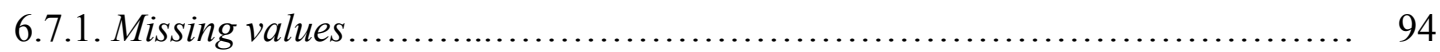

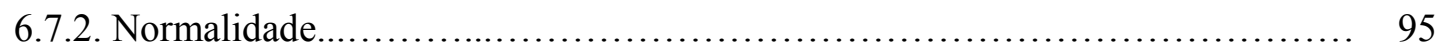

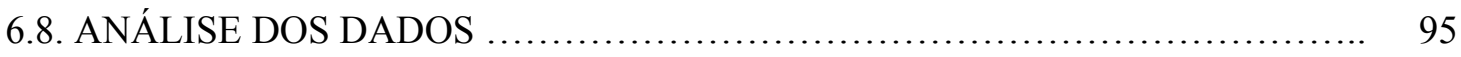

6.8.1. Validação do instrumento de mensuração.............................................................. 96

6.8.1.1. Pré-teste........................................................................................... 101

6.8.1.2. Validade de constructo ............................................. 102

6.8.1.3. Esquema geral do processo de validação da escala do PSM............................. 114

CAPÍTULO 7 - ANÁLISE E DISCUSSÃO DOS RESULTADOS.................................. 115

7.1. VALIDADE DE CONSTRUCTO_................................................................... 116

7.1.1. Análise da correlação entre os constructos do PSM e do Comprometimento 116 Organizacional.

7.1.2. Análise exploratória dos componentes do PSM - Public Service

Motivation.

7.1.3. Análise confirmatória dos componentes do PSM - Public Service Motivation 
7.1.4. Análise fatorial confirmatória entre os componentes do PSM - Public Service Motivation

7.1.4.1. Comparação dos modelos americano e brasileiro estimados.

7.1.5. Modelagem de equações estruturais com os componentes da escala de MSP Motivação no Serviço Público.

CAPÍTULO 8 - CONSIDERAÇÕES FINAIS

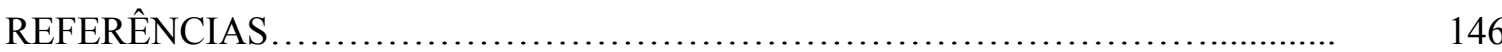

ANEXO - Questionário.................................................. 154 


\section{LISTA DE FIGURAS}

Figura 1. Pirâmide da Hierarquia das Necessidades de Maslow ........................... 28

Figura 2. Contínuos do grau de satisfação ou insatisfação ................................... 30

Figura 3. Teoria do Estabelecimento de Metas .................................................. 36

Figura 4. Resumo da Teoria da Expectativa ........................................................ 41

Figura 5. Processo de determinação da validade de constructo de uma escala envolvendo a conexão do domínio teórico e o domínio das medidas...................... 103

Figura 6. Processo de validação de constructo do instrumento de MSP -

Motivação no Serviço Público.

Figura 7 - Esquema do processo geral de validação da escala de PSM - Public

Service Motivation.

114

Figura 8 - Índices para avaliar a adequação da amostra...................................... 119

$\begin{array}{ll}\text { Figural 9- Comunalidades para os indicadores da análise fatorial exploratória... } & 120\end{array}$

Figura 10 - Dimensão latente Auto-sacrificio..................................................... 123

Figura 11 - Dimensão latente Compaixão........................................................... 124

Figura 12 - Dimensão latente Comprometimento com o interesse público............. 125

Figura 13 - Output do Amos com o resultado da primeira análise confirmatória para a dimensão latente Atração pela formulação de políticas públicas................ 126

Figura 14 - Modelo 1 com quatro dimensões latentes do PSM.............................. 129

Figura 15 - Modelo 2 com três dimensões latentes do PSM................................... 132

Figura 16 - Modelo estrutural esquematizado da MSP e suas respectivas

hipóteses................................................................................................. 138

Figural 17 - Modelo estrutural estimado........................................................... 139 


\section{LISTA DE QUADROS}

Quadro 1. Resumo das principais teorias motivacionais do início dos anos 40 até o início dos anos 70 23

Quadro 2. Teoria da Eqüidade .......................................................................

Quadro 3. Categorias de base teórica ............................................................... 46

Quadro 4. Relação das dimensões do PSM com as categorias da base teórica 48

Quadro 5. Questionário traduzido do PSM dividido em relação às subescalas .... $\quad 90$

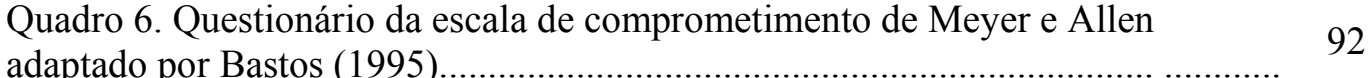

Quadro 7. Principais tipos de validade, objetivos, métodos e usos mais comuns .. 100 


\section{LISTA DE TABELAS}

Tabela 1. Composição da amostra.

Tabela 2 - Hipóteses de pesquisa e técnica estatística utilizada

Tabela 3 - Resumo dos principais índices de ajuste de modelos e seus respectivos valores de corte de acordo com o tamanho da amostra e do número de variáveis observadas.

Tabela 4 - Médias e desvios-padrão dos constructos de MSP e Comprometimento Organizacional e suas dimensões.

Tabela 5 - Correlação de Spearman entre os constructos de MSP, de Comprometimento Organizacional e suas respectivas dimensões

Tabela 6 - Resultado da modelagem de equações estruturais - Modelo 1

Tabela 7 - Comparação das medidas de ajuste do modelo (1) americano e do brasileiro

Tabela 8 - Coeficientes de correlação entre as dimensões latentes do modelo 1 ..... Tabela 9 - Comparação das medidas de ajuste do modelo (2) americano e do brasileiro.

Tabela 10 - Resumo dos valores do teste $x^{2}$ e das medidas de ajuste dos modelos americano e brasileiro

Tabela 11 - Resumo dos valores do teste $x^{2}$ e das medidas de ajuste dos modelos da análise fatorial confirmatória e da modelagem de equações estruturais. 


\section{CAPÍTULO 1 - INTRODUÇAO}

Os motivos que levavam as pessoas a procurar emprego no setor público baseavam-se, principalmente na busca pela segurança, tanto financeira quanto de carreira, além de benefícios que o emprego público trazia, como, por exemplo, o direito de férias, de horas de trabalho fixas etc. O contexto dos dias atuais está um pouco modificado, uma vez que reformas foram feitas no Estado a fim de promover mudanças na máquina administrativa do governo. Isso parece ter acontecido em conseqüência da mudança nos fatores que levam o indivíduo a decidir sobre sua profissão, tais como maior qualidade de vida e dedicação a outras atividades fora da organização em que trabalha.

A Administração Pública burocrática existente antes da reforma administrativa proposta nos anos 90, baseava-se em idéias principalmente de Frederick Taylor e Max Weber. Entre elas, eram bem características do governo: a separação das funções de gerenciamento e de execução, divisão do trabalho, alta especialização, estabelecimento de regras, padronização das tarefas, hierarquia e impessoalidade nas organizações, eficiência como conseqüência da obediência às regras (PACHECO,1998).

Assim, a Administração Pública refletia uma imagem das organizações públicas no Brasil, segundo Côrtes (2005), de pouca demanda de esforço de trabalho, de salários baixos, poucos benefícios, clima de insatisfação e com um nível de eficiência muito baixo, demonstrando a inadequação do sistema vigente. Em 1995, então, o governo iniciou uma reforma na gestão pública nas três esferas (federal, estadual e municipal) e criou o Ministério da Administração Federal e Reforma (MARE). O objetivo era implementar um modelo de gestão menos burocrático e mais perto do modelo empresarial, ou seja, o Estado atuaria 
buscando maior eficiência, transparência e contratando profissionais que assumissem o papel de gestores públicos.

Segundo Pereira (2002), a reforma não estava na agenda do país, mas quando o Congresso aprovou a emenda constitucional em 1998, a implementação da reforma baseou-se no exemplo do Chile, ou seja, foi de responsabilidade de um novo Ministério do Planejamento, Orçamento e Gestão (uma fusão do MARE com o Ministério do Planejamento). Essa proposta foi adotada pelo Presidente Fernando Henrique Cardoso em seu segundo mandato, que se iniciou em 1999. Assim, Pereira (2002, p. 21) observa que

desde essa data, a reforma vem sendo implementada gradualmente, sob a responsabilidade do novo ministério e da Secretaria de Gestão. Em vez de ser chamada "reforma gerencial", um novo e similar nome foi adotado: "Gestão Empreendedora". Avanços estão ocorrendo, não somente no nível federal, mas também nos níveis estaduais e municipais, desde que a reforma de 1995 mudou a agenda de todo o país. Transformações normalmente evoluem gradualmente, o que faz acreditar que as reformas foram a pique. De fato, não falharam. As reformas administrativas principais têm um momento crítico de mudança institucional e cultural, e um processo longo e incerto de implementação. O que é importante saber é se as novas visões têm sido aceitas e se tornaram dominantes na sociedade e entre os dirigentes públicos - e eu não tenho dúvida disso.

Mais especificamente no que tange aos recursos humanos, a profissionalização dos servidores públicos teve prioridade. Algumas ações realizadas nesse sentido foram: a revisão das relações de trabalho, aproximação do mercado de trabalho do setor público com o do setor privado por meio de correção de diferenças de remuneração, retomada de concursos públicos e revisão das carreiras (PACHECO, 1998).

As tendências no campo dessas reformas apontam para o uso da avaliação como instrumento para o aperfeiçoamento da gestão governamental e o aumento da eficiência. Dessa forma, os desafios que a nova gestão encontrará, tais como atender de forma eficiente, 
rápida e satisfatória às demandas crescentes e diferenciadas poderão ser transpostos com maior segurança e tranqüilidade.

Algumas das características desse novo cenário que se destacam são: maior exigência de responsabilidades dos servidores, a escassez de recursos e a pressão para melhorar a gestão financeira, bem como a consideração do público como cliente principal dos serviços prestados pelo Estado. Dessa forma, a avaliação e/ou o monitoramento do desempenho constituem parte indispensável da gestão moderna, ao lado da fixação de metas, contratos e ajustes para controlar a prestação de serviços públicos (SANTOS; CARSOSO, 2001).

Alguns dados do IBGE refletem essas novas características: o Estado brasileiro é atualmente, o maior empregador do país. Cerca de 7 milhões de pessoas se distribuem entre as esferas Federal, Estadual e Municipal, sendo que novas vagas estão sempre sendo oferecidas, o que torna atrativo o egresso no serviço público (informação pessoal) ${ }^{1}$. Outros fatores antes identificados somente nas empresas privadas atraem pessoas para as organizações públicas, como por exemplo, as carreiras, que oferecem oportunidades de crescimento profissional compensatórias, uma vez que se assemelham mais às oportunidades existentes no mercado de trabalho.

Nesse contexto de transformações por que as organizações vêm passando, elas modificaram a sua forma de conceber e entender o papel desempenhado pelas pessoas. E estas, por sua vez, também reformularam suas crenças e pressupostos sobre o papel do trabalho em suas vidas. As mudanças implementadas nas organizações a fim de melhorar o relacionamento destas com seus funcionários e de acompanhar o ritmo frenético das mudanças tecnológicas podem ser percebidas como geradoras de ansiedade, incertezas e

\footnotetext{
${ }^{1}$ Informação obtida através da leitura do texto "O maior empregador do Brasil", no site: http://www.centraldeconcursos.com.br/noticias/noticias.asp?id_noticia=346, acessado em 05/05/06
} 
ameaça às pessoas. Isso porque aquele emprego em que o indivíduo passava a vida toda não existe mais e o relacionamento a longo prazo com as organizações está cada vez mais raro.

É nesse cenário que surge a necessidade de compreensão mais profunda do comportamento motivacional. Está claro que a dificuldade pessoal na busca de um ajuste nesse contexto "requer o apoio de uma pesquisa mais aprofundada a respeito da dinâmica interior e das razões que impulsionam essa busca” (BERGAMINI, 1997, P. 16).

As organizações públicas possuem também um histórico de mudanças, não somente tecnológicas, mas provenientes de um processo de reforma do Estado que se iniciou em 1995 e se inserem nesse contexto de incertezas e reavaliação de papéis dos envolvidos. Dessa forma, o presente estudo se torna relevante tecnicamente por validar um instrumento de medida de motivação no setor público e cientificamente no que diz respeito ao desenvolvimento do processo de validação do instrumento, uma vez que o mesmo muitas vezes é ignorado na construção de escalas de mensuração de constructos. Além disso, o resultado final do presente estudo (a escala de motivação validada) vai ao encontro do objetivo primeiro da proposta de reforma administrativa, que segundo o Plano Diretor da Reforma do Aparelho do Estado (1995, p.32)é a

(...) valorização do servidor público eficiente, através do reconhecimento por parte do cidadão de seu trabalho e da conseqüente mudança de imagem perante a sociedade, envolvendo maior grau de autonomia, iniciativa e responsabilização, diminuindo controles formalistas e incentivando a adoção de uma política que seja conseqüente tanto com o bom desempenho quanto com a insuficiência do mesmo.

É relevante, também, para a literatura que trata do PSM - Public Service Motivation, uma vez que os principais estudos da área se concentram nos EUA e alguns em desenvolvimento na Bélgica e na Coréia. Essa escala também poderá ser aplicada em estudos 
(comparativos ou não), aqui no Brasil, nos setores privado e não governamental, a exemplo de estudos já realizados principalmente nos Estados Unidos.

O presente trabalho está estruturado em oito capítulos como apresentado a seguir. O capítulo introdutório faz uma contextualização do Brasil com relação à sua Administração Pública e também ao papel do servidor público nessas organizações; traz ainda o problema de pesquisa, assim como os objetivos de pesquisa geral e específicos.

No capítulo dois está a fundamentação teórica que compreende duas partes: a primeira descrevendo as principais teorias sobre motivação e a segunda apresentando a teoria do PSM - Public Service Motivation.

No capítulo três são feitas considerações acerca dos conceitos apresentados no capítulo anterior adicionados ao conceito de Comprometimento Organizacional, relacionando os três e justificando o porquê da utilização de uma terceira vertente conceitual no trabalho.

Os capítulos quatro e cinco descrevem a realidade do serviço e do servidor público no Brasil e nos EUA, além de descrever a legislação que rege as relações de trabalho de cada país.

No capítulo seis está exposta a metodologia da pesquisa, sendo apresentados o tipo de estudo realizado; o local onde foi coletada a amostra; a população e amostra da pesquisa; os instrumentos de mensuração utilizados; o procedimento de coleta de dados; o tratamento dos dados quanto à normalidade e missing values; e a análise de dados, com detalhamento dos dois tipos de validação utilizados (de constructo e de critério) e suas respectivas ferramentas estatísticas: análise fatorial exploratória, análise fatorial confirmatória, modelagem de equações estruturais e correlação de Spearman. 
No capítulo sete estão a apresentação e a análise dos resultados da pesquisa, subdivididas em cinco unidades: na primeira está exposto o teste da hipótese 1 , por meio da análise de correlação de Spearman realizada entre os constructos do PSM e de Comprometimento Organizacional; na segunda está exposta a análise exploratória dos componentes do PSM em que foi utilizada a análise fatorial exploratória a fím de verificar a adequação dos dados amostrais às ferramentas estatísticas que seriam utilizadas; na terceira, está exposta a análise confirmatória dos componentes do PSM para verificar se os indicadores de cada uma das dimensões latentes eram adequados aos mesmos; na quarta, está exposta a análise confirmatória dos componentes do constructo do PSM a fim de verificar se o ajuste geral do modelo é adequado; e na quinta está exposta a modelagem de equações estruturais realizada com o modelo originado da análise confirmatória a fim de verificar se a estrutura teórica é adequada para a realidade brasileira.

O capítulo oito traz as considerações finais em que os resultados são confrontados com os objetivos propostos para esta pesquisa. São feitas algumas sugestões para pesquisas futuras e também são ressaltados alguns aspectos relevantes da presente pesquisa para o tema estudado.

O anexo contém o questionário utilizado na coleta dos dados, o que permite que a escala de PSM possa ser utilizada em outros estudos. 


\subsection{PROBLEMA DE PESQUISA}

A escala de PSM - Public Service Motivation tem validade para a realidade brasileira?

\subsection{OBJETIVOS}

\subsubsection{Geral}

O objetivo principal deste estudo é validar a escala de medida do PSM - Public Service Motivation para a realidade das secretarias pesquisadas no município de Ribeirão Preto-SP.

\subsubsection{Específicos}

Traduzir o questionário do PSM - Public Service Motivation;

* Adaptar a linguagem da escala de medida do PSM - Public Service Motivation para a língua portuguesa por meio da validação de face;

* Cumprir as etapas da validar de constructo para a escala de medida do PSM - Public Service Motivation. 


\section{CAPÍTULO 2 - REFERENCIAL TEÓRICO}

\subsection{TEORIAS MOTIVACIONAIS}

Os fatores que motivam os indivíduos na organização vêm sendo amplamente estudados desde a década de 30 , por muitos pesquisadores, com diferentes focos. As teorias criadas a partir desses estudos identificam e explicam os vários motivos pelos quais as pessoas estão sempre buscando satisfazer suas necessidades, sejam elas pessoais e/ou profissionais. Vroom e Deci (1978) realizaram uma compilação de artigos que representam um cenário global do trabalho realizado até então, sobre motivação no ambiente de trabalho. O quadro 1 traz um resumo das principais teorias motivacionais desenvolvidas no início da década de 40 até o início da década de 70, e a seguir são comentadas algumas das principais teorias. 


\section{Quadro 1. Resumo das principais teorias motivacionais do início dos anos 40 até o início dos $\operatorname{anos} 70$}

\begin{tabular}{|c|c|c|}
\hline AUTOR & ANO & PRESSUPOSTOS BÁSICOS \\
\hline Taylor & 1911 & $\begin{array}{l}\text { Homem Econômico - o homem era motivado tão somente } \\
\text { por incentivos financeiros. }\end{array}$ \\
\hline Elton Mayo & $1924-1927$ & $\begin{array}{l}\text { Mudança do foco de interesse da administração da } \\
\text { organização formal para os grupos informais e suas inter- } \\
\text { relações e dos incentivos monetários para os psicossociais. }\end{array}$ \\
\hline Maslow & 1943 & $\begin{array}{l}\text { Hierarquia das Necessidades - todos os indivíduos } \\
\text { possuem necessidades que variam das mais básicas as } \\
\text { mais complexas. }\end{array}$ \\
\hline Brown & 1954 & $\begin{array}{l}\text { Brown baseia suas afirmações no trabalho de Elton Mayo, } \\
\text { e traz uma visão do homem intrinsecamente motivado, ou } \\
\text { seja, influenciado por motivos internos a ele e não } \\
\text { somente a motivos externos, ou extrínsecos. }\end{array}$ \\
\hline $\begin{array}{c}\text { Brayfield e } \\
\text { Crockett }\end{array}$ & 1955 & $\begin{array}{l}\text { Relação entre satisfação e desempenho no trabalho. Nem } \\
\text { sempre trabalhadores satisfeitos serão produtivos e nem } \\
\text { sempre o sucesso do esforço empregado a fim de } \\
\text { aumentar a satisfação no trabalho resultará } \\
\text { inevitavelmente em maior produtividade. }\end{array}$ \\
\hline Morse e Weiss & 1955 & $\begin{array}{l}\text { O fator econômico não era o único e nem o principal fator } \\
\text { motivacional para obter e reter os funcionários na } \\
\text { organização. Baseados no estudo de Maslow (1943), eles } \\
\text { destacaram fatores importantes que despertam um maior } \\
\text { interesse no trabalho pelos funcionários, como por } \\
\text { exemplo, a auto-estima. }\end{array}$ \\
\hline Ross e Zander & 1957 & $\begin{array}{l}\text { Indicaram a relação entre satisfação no trabalho e } \\
\text { turnover: quanto mais satisfeito no trabalho o indivíduo } \\
\text { está, menor é a ocorrência de perda do mesmo pela } \\
\text { organização. }\end{array}$ \\
\hline $\begin{array}{l}\text { Georgopoulos, } \\
\text { Mahoney e } \\
\text { Jones }\end{array}$ & 1957 & $\begin{array}{l}\text { O fator motivacional seria o significado de utilidade que } \\
\text { os empregados dão ao seu trabalho. Formulam um modelo } \\
\text { que inclui desejo ou utilidade do trabalho como resultados } \\
\text { relacionados e a probabilidade dos mesmos serem } \\
\text { incorporados. }\end{array}$ \\
\hline McGregor & 1957 & $\begin{array}{l}\text { Visão do homem intrinsecamente motivado, ou seja, } \\
\text { influenciado por motivos internos a ele e não somente a } \\
\text { motivos externos, ou extrínsecos. }\end{array}$ \\
\hline McClelland & 1957 & $\begin{array}{l}\text { Teoria com três fatores fundamentais para o entendimento } \\
\text { do comportamento humano no ambiente de trabalho: } \\
\text { necessidade de realização, de afiliação e de poder. }\end{array}$ \\
\hline March e Simon & 1958 & $\begin{array}{l}\text { Pesquisaram tanto os fatores que influenciam a satisfação } \\
\text { no trabalho quanto os que influenciam o indivíduo a } \\
\text { deixar a organização. }\end{array}$ \\
\hline $\begin{array}{l}\text { Argyle, } \\
\text { Gardner e } \\
\text { Cioffi }\end{array}$ & 1958 & $\begin{array}{l}\text { Resumiram os resultados de várias investigações sobre os } \\
\text { efeitos no tipo de comportamento de supervisão na } \\
\text { produtividade da organização e apresentaram os resultados } \\
\text { de uma pesquisa realizada numa fábrica inglesa. }\end{array}$ \\
\hline
\end{tabular}




\begin{tabular}{|c|c|c|}
\hline Herzberg & 1959 & $\begin{array}{l}\text { A satisfação ou insatisfação devem ser consideradas } \\
\text { dimensões diferentes, ao invés de diferentes resultados de } \\
\text { uma mesma dimensão. O autor argumenta que a satisfação } \\
\text { deriva do contentamento com o trabalho enquanto que a } \\
\text { insatisfação deriva do ambiente do trabalho. }\end{array}$ \\
\hline Locke & 1960 & $\begin{array}{l}\text { Um objetivo a ser alcançado é a maior fonte de motivação } \\
\text { no trabalho, pois determina para o funcionário o quanto de } \\
\text { esforço deverá ser empreendido na tarefa e o que precisa } \\
\text { ser feito. Objetivos específicos melhoram o desempenho; } \\
\text { objetivos difíceis, quando aceitos, melhoram mais o } \\
\text { desempenho do que aqueles considerados fáceis; o } \\
\text { feedback conduz a melhores desempenhos. }\end{array}$ \\
\hline Likert & 1961 & $\begin{array}{l}\text { Maior concessão de autonomia aos funcionários, gerando } \\
\text { maior comprometimento com a organização e com seus } \\
\text { objetivos. }\end{array}$ \\
\hline Maier e Hayes & 1962 & Processo de decisão participativo. \\
\hline Leavitt & 1962 & $\begin{array}{l}\text { Atenta para o cuidado com relação às teorias normativas } \\
\text { de gestão baseadas no pressuposto de que é preciso } \\
\text { coordenar as tarefas da organização orientadas somente } \\
\text { pelos esforços dos indivíduos. }\end{array}$ \\
\hline Vroom & 1964 & $\begin{array}{l}\text { Relação entre a "quantidade" de motivação na eficiência } \\
\text { do desempenho. }\end{array}$ \\
\hline Katz & 1964 & $\begin{array}{l}\text { Visão integrada de conceitos necessários ao entendimento } \\
\text { do papel da motivação no desempenho tanto do indivíduo } \\
\text { isolado quanto da organização como um todo. }\end{array}$ \\
\hline Leavitt & 1964 & $\begin{array}{l}\text { Expõe métodos de mudança organizacional. Distingue } \\
\text { estrutura, tecnologia e pessoas como pontos determinantes } \\
\text { da mudança e coloca que ela traz pressões não somente } \\
\text { em nível organizacional, mas também individual. }\end{array}$ \\
\hline Adams & 1965 & $\begin{array}{l}\text { Teoria da equidade - essa teoria ilustra a percepção de } \\
\text { igualdade por parte dos funcionários, por meio de } \\
\text { comparações sobre seu trabalho e o dos outros. }\end{array}$ \\
\hline Herzberg & 1966 & $\begin{array}{l}\text { A satisfação ou insatisfação devem ser consideradas } \\
\text { dimensões diferentes, ao invés de diferentes resultados de } \\
\text { uma mesma dimensão. O autor argumenta que a satisfação } \\
\text { deriva do contentamento com o trabalho enquanto que a } \\
\text { insatisfação deriva do ambiente do trabalho. }\end{array}$ \\
\hline $\begin{array}{l}\text { Opsahl e } \\
\text { Dunnette }\end{array}$ & 1966 & $\begin{array}{l}\text { Avaliaram criticamente as teorias e pesquisas existentes } \\
\text { relacionadas com os efeitos da compensação financeira na } \\
\text { motivação do indivíduo. }\end{array}$ \\
\hline Tannerbaum & 1966 & $\begin{array}{l}\text { Apresenta uma conclusão mais ampla sobre uma pesquisa } \\
\text { realizada sobre os efeitos do trabalho em grupo na } \\
\text { produtividade. }\end{array}$ \\
\hline Lawler e Porter & 1967 & $\begin{array}{l}\text { Modelo proposto incluindo os efeitos de habilidades e } \\
\text { percepção de papel como variáveis motivacionais, além do } \\
\text { fator desejo ou utilidade do trabalho. }\end{array}$ \\
\hline
\end{tabular}




\begin{tabular}{|c|c|l|}
\hline Trist & 1968 & Discute a evolução e o perfil atual desta tecnologia. \\
\hline Alderfer & 1969 & $\begin{array}{l}\text { Teoria ERG - baseou-se na Teoria da Hierarquia das } \\
\text { Necessidades de Maslow para desenvolver a teoria ERG, } \\
\text { ou Existence, Relatedness and Growth (existência, } \\
\text { relacionamento e crescimento). }\end{array}$ \\
\hline Vroom & 1969 & $\begin{array}{l}\text { Estuda os determinantes das atitudes dos indivíduos para } \\
\text { com seus trabalhos, concluindo com quatro variáveis que } \\
\text { devem ser incluídas nas teorias sobre satisfação no } \\
\text { trabalho. }\end{array}$ \\
\hline Lawler & 1969 & $\begin{array}{l}\text { Lida com o plano de trabalho propriamente dito: porque } \\
\text { ele está relacionado com o desempenho e quais mudanças } \\
\text { especificamente são esperadas a fim de resultarem em } \\
\text { determinados desempenhos. }\end{array}$ \\
\hline Skinner & 1971 & $\begin{array}{l}\text { Teoria do Reforço - a partir de suas experiências de } \\
\text { condicionamento animal, elaborou a teoria conhecida } \\
\text { como “Condicionamento Operante", que trabalha com } \\
\text { dois principais elementos: o reforço positivo e o reforço } \\
\text { negativo. }\end{array}$ \\
\hline Lawler & $\begin{array}{l}\text { Teoria da motivação por impulso - considera o } \\
\text { aprendizado anterior como preditor do comportamento de } \\
\text { resposta, formando, assim, um repertório psíquico, como } \\
\text { é chamado pelos behavioristas. Por meio desses fatores é } \\
\text { possível, então, predizer que o comportamento do } \\
\text { indivíduo será de aproximação quando houver um evento } \\
\text { satisfatório e de fuga quando houver um evento } \\
\text { insatisfatório. }\end{array}$ \\
\hline
\end{tabular}

\subsubsection{Teoria das Necessidades de Maslow}

Maslow focou seus estudos na teoria da personalidade e do desenvolvimento humano.

Seguindo o conceito do homem complexo, ele afirmava que o indivíduo possuía necessidades complexas que poderiam ser hierarquizadas. Ele não considerava em seus estudos a eficiência organizacional, presente na maioria - senão em todos - os estudos anteriores (MOTTA; VASCONCELOS, 2004). 
As necessidades básicas podem ser observadas na figura 1 e foram definidas por Maslow, em 1943, da seguinte maneira (VROOM, DECI, 1978):

* As necessidades fisiológicas: o ponto de partida para a teoria da motivação são as chamadas orientações psicológicas. É necessário, primeiramente, uma revisão em dois conceitos a fim de se entender melhor do que se tratam essas necessidades básicas: homeostase e o fato de que o apetite é um eficiente indicador das necessidades do corpo. O primeiro conceito se refere ao esforço do corpo em manter a sua estabilidade interna. $\mathrm{O}$ segundo conceito remete à falta nos indivíduos de amor, segurança, estima, entre outros e que acabam por se manifestar por meio da fome. Assim, outras necessidades surgem (maiores), e mais do que a "fome psicológica", dominam o organismo. Quando outras surgem (maiores ainda), também estas últimas são supridas e substituídas pelas novas, criando um ciclo. A implicação mais importante disso tudo é que a gratificação se torna um conceito tão importante quanto o conceito de privação na teoria das motivações, pois ela liberta o organismo da dominação de uma necessidade psicológica, permitindo assim, o surgimento de objetivos mais sociais.

* A necessidade de segurança: como citado acima, quando as necessidades fisiológicas estão satisfeitas, surgem outras, que podem ser categorizadas como necessidade de segurança. Da mesma maneira que um homem satisfeito não sente mais fome, também um homem seguro não sente mais medo do perigo. Um aspecto mais amplo dessa procura de estabilidade e segurança é a preferência comum pelo conhecido do que pelo desconhecido, pelo familiar do que pelo não familiar.

A necessidade de afeto: satisfeitas as duas necessidades anteriores, surge uma nova, a necessidade de afeto, amor e pertença. O indivíduo irá querer conseguir um lugar no 
grupo mais do que qualquer coisa, e poderá nem se lembrar de que um dia chegou a sentir fome.

* A necessidade de status e estima: as pessoas possuem o desejo de uma avaliação de si mesmas estável, com uma base firme, por auto-respeito, auto-estima e estima de outros. Essas necessidades podem ainda ser divididas em duas "categorias": 1) o desejo por força, adequação, confiança em enfrentar o mundo, independência e liberdade e 2) desejo por reputação ou prestígio, reconhecimento, atenção, importância. A satisfação dessas necessidades leva a autoconfiança, capacidade, força e sentimento de utilidade ao mundo.

A necessidade de auto-realização: mesmo depois que todas essas necessidades estiverem satisfeitas, ainda sim podemos esperar o surgimento de mais uma necessidade, a não ser que o indivíduo esteja fazendo o que realmente nasceu para fazer. O que um homem pode ser, ele deve ser. Procura-se, aqui, pelo desejo de autorealização, de se tornar tudo o que uma pessoa é capaz de se tornar. Esse desejo pode ser suprido de diferentes formas que variam de pessoa para pessoa, como, por exemplo, a experiência da maternidade. 


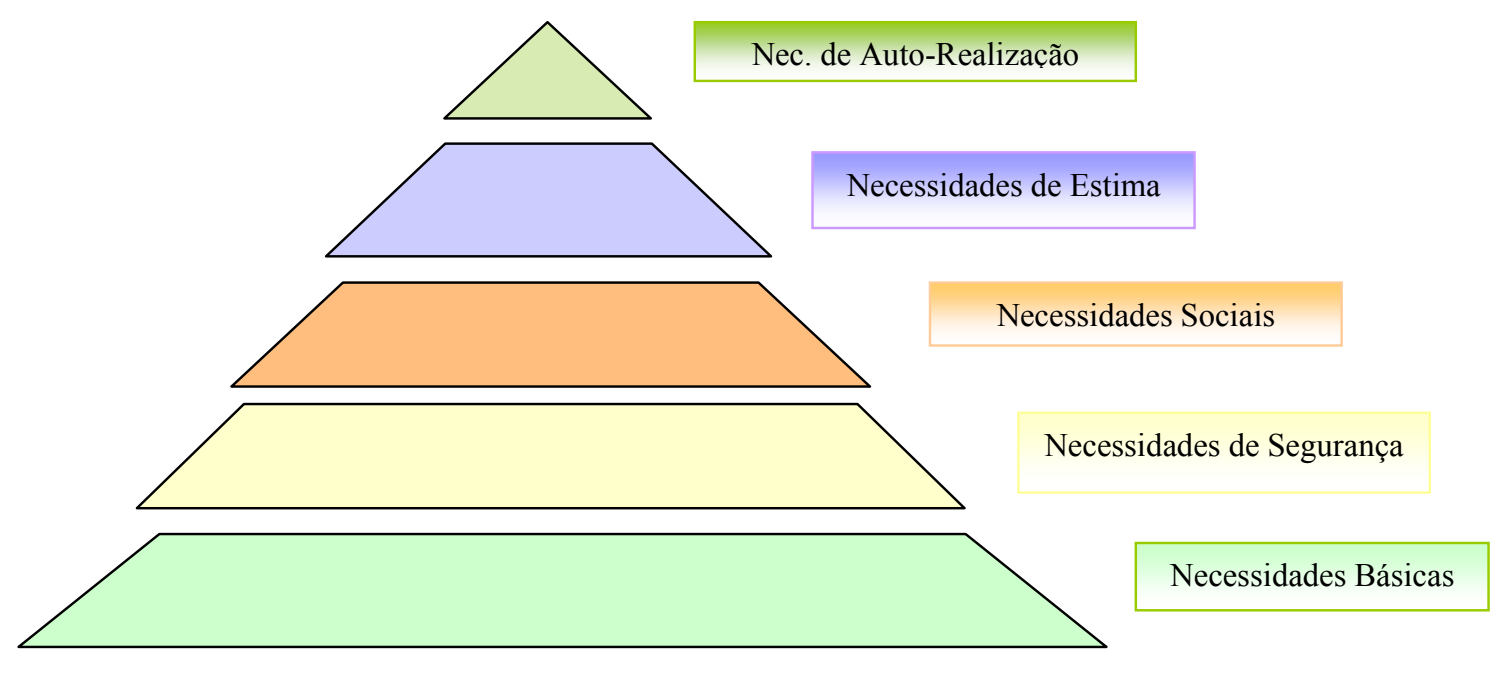

Figura 1. Pirâmide da Hierarquia das Necessidades de Maslow

Fonte: Adaptado de Motta e Vasconcelos, 2002, p. 74.

Vroom e Deci (1978) apresentam, ainda, algumas pré-condições colocadas por Maslow para a satisfação das necessidades citadas.

Outras características das necessidades básicas:

O grau de fixação da hierarquia das necessidades básicas: até o presente momento, a ordem da hierarquia pareceu ser fixa, mas na verdade, não há uma hierarquia rígida, pois apesar de a maioria das pessoas a apresentarem na ordem elaborada, há situações em que não se enquadram, como, por exemplo, em certas pessoas, o nível de aspiração pode ser permanentemente nulo ou muito baixo.

Graus de satisfação relativa: uma necessidade não é totalmente suprida até que aparece a outra; uma descrição melhor disso seria dizer que há um decréscimo da porcentagem de satisfação de uma necessidade e aumento da porcentagem de satisfação de outra, que então, se sobrepõem. 


\subsubsection{Teoria dos Dois Fatores}

Esta teoria, formulada por Herzberg, em 1959, explica como o ambiente de trabalho e o trabalho em si interagem-se para produzir motivação. Esta resulta de dois fatores (MAXIMIANO, 2004, p.193-294):

* Fatores Motivacionais ou intrínsecos:

- Conteúdo do trabalho em si;

- Sentido de realização de algo importante;

- Exercício da responsabilidade;

- Possibilidade de crescimento;

- Orgulho e sentimento de prestígio decorrentes da profissão;

- Reconhecimento pelo trabalho bem-feito.

Fatores higiênicos ou extrínsecos:

- Estilo de supervisão do chefe;

- Relações pessoais com os colegas;

- Salário;

- Políticas de administração de pessoal;

- Condições físicas e de segurança do trabalho.

Uma das primeiras afirmações de Herzberg juntamente com Mausner, Peterson e Capwell, em 1957, foi que os fatores que influenciam a satisfação no trabalho poderiam ser classificados de acordo com sua contribuição primária para uma situação de satisfação ou de insatisfação. A partir de 1959, houve um grande esforço no sentido de desenvolver esse estudo inicial, e então, dois aspectos se destacaram (ver figura 2) (LAWLER, 1973): 
* A teoria afirma que há um contínuo para o fator satisfação e outro para insatisfação, separadamente. Não há um contínuo único, que vai da satisfação, passando pela neutralidade até a insatisfação;

* Existem dois contínuos: um que vai da satisfação à neutralidade e outro que vai da insatisfação à neutralidade.

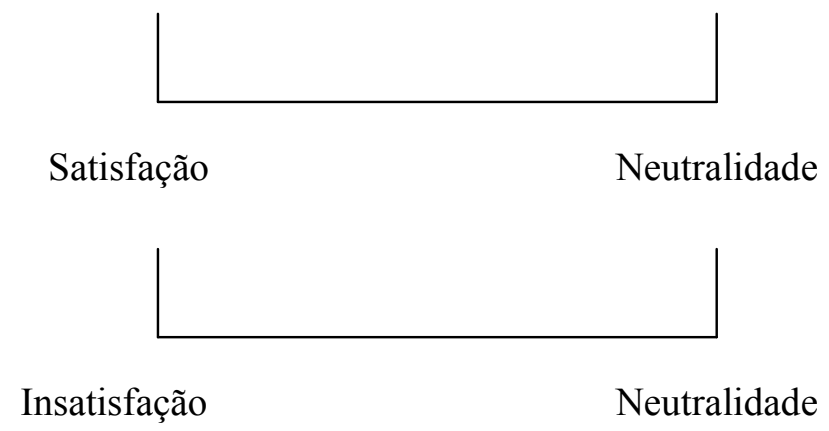

Figura 2. Contínuos do grau de satisfação ou insatisfação

Fonte: Lawler, 1973, p.70.

A idéia é que o oposto da satisfação não é a insatisfação, mas a não-insatisfação; e o oposto da satisfação é a não-satisfação. Ou ainda: fatores higiênicos estão associados à insatisfação e fatores motivacionais, à satisfação (MAXIMIANO, 2004). 


\subsubsection{Teoria X e Teoria $Y$}

McGregor, em 1957, propôs duas visões distintas sobre o ser humano: a Teoria X e a Teoria Y. A primeira trazia uma imagem negativa do homem e a segunda o oposto, uma imagem positiva. De acordo com a maneira em que os executivos tratavam seus funcionários, McGregor concluiu que algumas premissas estavam por trás desse comportamento. As premissas para cada uma das teorias são as seguintes (ROBBINS, 2005, p.134):

Teoria X:

* É da natureza dos funcionários não gostarem de trabalhar, e eles evitarão o trabalho de todas as formas possíveis;

Devido à preguiça inata, os funcionários precisam ser controlados, coagidos ou ameaçados com punições a fim de atingir as metas da organização;

* Os funcionários evitam responsabilidades e procuram orientação formal sempre que possível;

* Os funcionários demonstram pouca ambição e dão maior importância à segurança do que a outros fatores relacionados ao trabalho.

Teoria Y:

* O trabalho pode ser considerado pelos funcionários tão natural quanto descansar ou se divertir;

* Se houver comprometimento dos funcionários com os objetivos da organização, eles demonstrarão autocontrole e auto-orientação; 
* A pessoa considerada mediana é naturalmente capaz de aprender e até a buscar a responsabilidade;

Tomar decisões inovadoras não é privilégio de funcionários da alta hierarquia, mas também de qualquer pessoa.

Baseando-se no trabalho de Maslow (Teoria da Hierarquia das Necessidades), McGregor relacionou o comportamento dominante dos indivíduos, para a Teoria X com os níveis mais baixos da pirâmide de necessidades, enquanto que para a Teoria $\mathrm{Y}$ o comportamento relaciona-se com o nível mais alto da pirâmide de Maslow (ROBBINS, 2005).

\subsubsection{Tríade Realização-Poder-Afiliação (Teoria ERG)}

Clayton Alderfer baseou-se na Teoria da Hierarquia das Necessidades de Maslow para desenvolver a teoria ERG, ou Existence, Relatedness and Growth (existência, relacionamento e crescimento) (ROBBINS, 2005). Para Alderfer, existem três categorias de necessidades essenciais (DUBRIN, 2003, p. 116):

Necessidade de realização: é o desejo de conseguir algo difícil por seus próprios méritos. Os indivíduos com esse tipo de necessidade procurarão por recompensas financeiras que reflitam o quão bem estão se saindo em suas atividades. Procuram sempre estabelecer metas realísticas (nem fáceis demais nem difíceis demais), assumem riscos e desejam feedback sobre seu desempenho. 
Necessidade de Poder: é o desejo de controlar outras pessoas, para influenciar seu comportamento e ser responsável por elas. Os indivíduos com esse tipo de necessidade procuram controlar, além de pessoas, recursos (dinheiro e imóveis) e passam o tempo pensando em como influenciar as pessoas a sua volta e em como ganhar uma posição de status.

Necessidade de afiliação: é o desejo de estabelecer e manter um relacionamento amigável e caloroso com os outros. Os indivíduos com esse tipo de necessidade prezam mais pela cooperação do que pela competição. Procuram se integrar em atividades que permitam um relacionamento mais íntimo.

\subsubsection{Teoria da Eqüidade}

A teoria de Adams (1965), ilustra a percepção de igualdade por parte dos funcionários, por meio de comparações sobre seu trabalho e o dos outros. Se o indivíduo percebe a situação como justa, fica tudo sob controle; mas se acontece ao contrário, ou seja, se ele percebe a situação como injusta, ele experimenta uma tensão de eqüidade, como pode ser observado no quadro 2 (ROBBINS, 2005).

Quadro 2. Teoria da Eqüidade

\begin{tabular}{|c|c|}
\hline Comparação(*) & Percepção \\
\hline $\mathrm{R} / \mathrm{IA}<\mathrm{R} / \mathrm{IB}$ & Injustiça por ser sub-recompensado \\
\hline $\mathrm{R} / \mathrm{IA}=\mathrm{R} / \mathrm{IB}$ & Eqüidade \\
\hline $\mathrm{R} / \mathrm{IA}>\mathrm{R} / \mathrm{IB}$ & Injustiça por ser super-recompensado \\
\hline
\end{tabular}

(*) Onde R/IA significa relação entre resultado e investimento de um funcionário A e R/IB de um funcionário $\mathrm{B}$

Fonte: Robbins, 2005, p.146. 
Para que o indivíduo tenha essa percepção, ele realiza essas comparações com relação a pontos de referência que ele escolhe, a depender das informações que ele possui sobre essas referências, assim como do grau de influência destes sobre o indivíduo. Esses pontos de referência podem ser quatro, de acordo com Robbins (2005):

Próprio-interno: comparações feitas quando o funcionário já ocupou outra posição dentro da mesma empresa;

* Próprio-externo: comparações feitas quando o funcionário já ocupou outra posição fora de sua empresa atual;

* Outro-interno: comparações feitas com outra pessoa ou grupo da mesma empresa;

* Outro-externo: comparações feitas com outra pessoa ou grupo de fora da empresa.

Segundo essa teoria, o indivíduo se encontra mais motivado quando percebe uma situação de eqüidade com o outro indivíduo comparado. Quando essa percepção é de injustiça, ele tende a se engajar em uma das seguintes situações (DUBRIN, 2003, p. 126): alterar os resultados, alterar os recursos, distorcer a percepção, mudar a fonte de referência ou deixar a situação.

\subsubsection{Teoria do Reforço}

Pesquisador pertencente à abordagem behaviorista em Psicologia, Skinner, no ano de 1971, elaborou, a partir de suas experiências de condicionamento animal, a teoria conhecida como "Condicionamento Operante", que trabalha com dois principais elementos: o 
reforço positivo e o reforço negativo. Para Skinner, esses elementos são capazes de estruturar ou extinguir determinados tipos de comportamentos (BERGAMINI, 1997).

São considerados reforços positivos quando a resposta é acompanhada de um comportamento adequado, ou agradável e como negativos quando a resposta é acompanhada de um comportamento desagradável ou inadequado. Qualquer tipo de reforço resulta em aprendizagem, pois fortalecem uma resposta de aumentar a possibilidade de sua repetição (ROBBINS, 2005).

Dubrin (2003, p. 121-22) coloca quatro estratégias para modificar o comportamento do indivíduo ou de um grupo:

Reforço positivo: aplicação de uma conseqüência prazerosa quando uma pessoa retorna com a resposta desejada;

* Motivação da evitação (ou aprendizagem de evitação): recompensa para a pessoa pela retirada de uma conseqüência negativa, (reforço negativo);

* Extinção: enfraquecimento ou diminuição da freqüência de um comportamento indesejável pela remoção ou premiação dada a esse comportamento;

* Punição: apresentação de uma conseqüência indesejável para um determinado comportamento.

Segundo Bergamini (1997), os teóricos da abordagem comportamental afirmam que a reação é uma forma de comportamento que foi sendo adquirida e internalizada aos hábitos dos indivíduos e que, dessa forma, independe da consciência dos que estão sendo controlados. Nessa situação, portanto, não se pode afirmar que os indivíduos estão sendo motivados por outros, e sim que estão sendo colocados em movimento por meio de hábitos convencionados como adequados pelo condicionador. 


\subsubsection{Teoria do Estabelecimento de Metas}

Locke, no ano de 1960, propôs que um objetivo a ser alcançado é a maior fonte de motivação no trabalho, pois determina para o funcionário o quanto de esforço deverá ser empreendido na tarefa e o que precisa ser feito. Objetivos específicos melhoram o desempenho; objetivos difíceis, quando aceitos, melhoram mais o desempenho do que aqueles considerados fáceis; o feedback conduz a melhores desempenhos (ROBBINS, 2005).

A figura 3 resume algumas descobertas consistentes, listadas a seguir (DUBRIN, 2003, p. 119):

Metas específicas levam a um melhor desempenho do que metas generalizadas;

O desempenho geralmente aumenta na proporção direta da dificuldade da meta;

Para que as metas melhorem o desempenho, é necessário que o empregado as aceite;

As metas são mais eficazes quando são usadas para avaliar o desempenho;

As metas deveriam estar vinculadas a feedback e recompensas;

* O estabelecimento de metas de grupo é tão importante quanto o estabelecimento de metas individuais;

* Uma orientação de metas de aprendizagem melhora mais o desempenho do que a orientação de metas de desempenho.

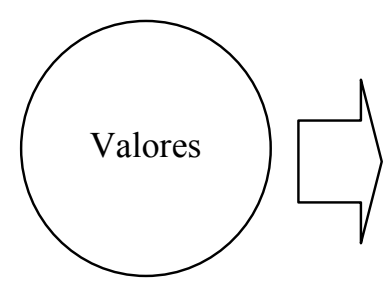

Metas que são:

Específicas

Duras, porém realísticas

Aceitas pelas pessoas

Usadas para avaliar desempenho

Ligadas a feedback e recompensas

Estabelecidas por indivíduos ou grupos

Orientadas para a aprendizagem

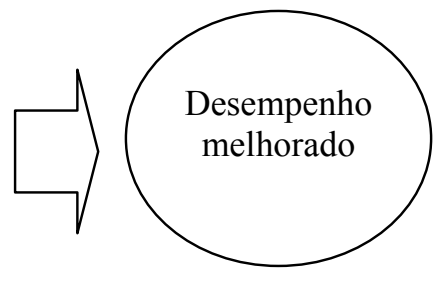

Figura 3. Teoria do Estabelecimento de Metas

Fonte: Dubrin, 2003, p. 119. 


\subsubsection{Teoria da Motivação por Impulso}

Lawler (1973) cita a lei do efeito de Thorndike, do ano de 1911, como base para testes de teorias motivacionais e, conseqüentemente, para a teoria da motivação por impulso, pois ela considera o aprendizado anterior como preditor do comportamento de resposta, formando, assim, um repertório psíquico (BERGAMINI, 1990), como é chamado pelos behavioristas. Por meio desses fatores é possível, então, predizer que o comportamento do indivíduo será de aproximação quando houver um evento satisfatório e de fuga quando houver um evento insatisfatório.

Segundo Lawler (1973), Hull foi um dos primeiros pesquisadores na área, e desenvolveu, em 1943, uma fórmula que sugeria que o comportamento é influenciado por uma combinação de impulso e hábito, sendo que a relação de multiplicação existente indica que a menos que um impulso esteja presente, não haverá um ímpeto de resposta. $\mathrm{O}$ autor denominou essa relação estímulo-resposta de "ímpeto de responder" ou "força do hábito efetivo":

$$
s E_{R}={ }_{s} H_{R} X D
$$

Fonte: Lawler, 1973, p. 42.

Sendo que:

* ${ }_{\mathrm{S}} \mathrm{E}_{\mathrm{R}}=$ Força do hábito efetiva (effective habit strength)

* ${ }_{\mathrm{S}} \mathrm{H}_{\mathrm{R}}=$ Força do hábito (habit strength)

* $\mathrm{D}=$ Impulso (drive)

\footnotetext{
${ }^{2}$ Traduzido pela autora da expressão: "impetus to respond".
} 
O comportamento é influenciado pelo impulso de duas formas, basicamente: por uma influência estimulante ou por uma influência parcialmente direcionada. A primeira faz parte do papel principal dessa teoria, que é prover o estímulo. A segunda está relacionada com as necessidades biológicas, que já possuem padrões de resposta a determinados estímulos e que, portanto, influenciam de forma parcial e direta o impulso (LAWLER, 1973).

Após o desenvolvimento do conceito de impulso (drive), Hull se concentrou no fator "força do hábito", que ele definiu como sendo a "conecção entre o estímulo e a resposta" (HULL, 1943, apud LAWLER, 1973, p.43) ${ }^{3}$, e que depende de quatro fatores:

* A continuidade do estímulo e resposta durante o treinamento;

* A proximidade do evento de E-R (estímulo-resposta) de um reforço positivo;

* O número de reforços positivos;

* A magnitude dos reforços positivos durante o treinamento.

Assim, o autor afirmava que o quanto de recompensa obtida não era o fator que determinava o comportamento, e sim as experiências anteriores relacionadas àquele fato. Posteriormente, com o advindo das críticas, o conceito de "quantidade de incentivo" inserido como uma variável separada em sua equação, que passou então a figurar da seguinte forma (LAWLER, 1973):

$$
s E_{R}=s H_{R} \times D \times K
$$

Fonte: Lawler, 1973, p. 44.

\footnotetext{
${ }^{3}$ HULL, C. L. Principles of Behavior. New York: Appleton-Century-Crofts, 1943.

${ }^{4}$ Traduzido pela autora da expressão: "amount of incentive".
} 
Sendo que:

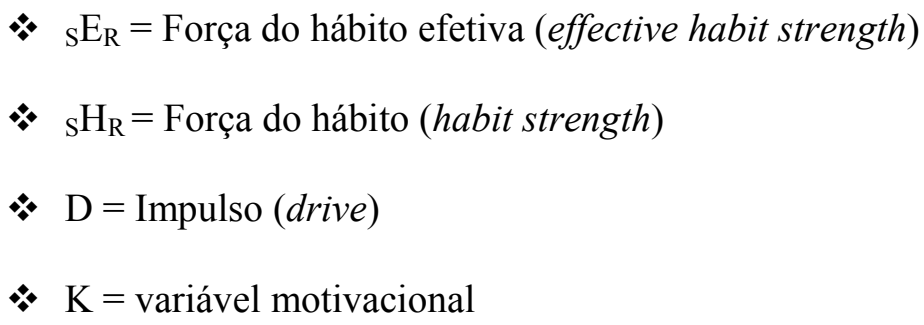

Segundo Lawler (1973) essa nova variável refere-se à reação antecipada ao objetivo que pode se transformar rapidamente em força, à medida que o tamanho da recompensa se modifica e é tratada como variável motivacional, assim como D (impulso), porque também estimula os hábitos.

\subsubsection{Teoria da Expectativa}

Durante a década de 30, desenvolveu-se a Teoria da Expectativa. Autores como Tolman, em 1932 e Lewin, em 1935, apresentaram uma orientação para uma abordagem mais cognitiva e com termos como "valência" e "força". Depois disso, diversas outras variações foram apresentadas, sendo que todas convergiam para a seguinte afirmação: valência e expectativa combinam-se multiplicando-se, para determinar o comportamento (LAWLER, 1973). Dubrin (2003, p. 122) coloca que, segundo a teoria da expectativa, "a motivação é resultante de escolhas deliberadas para se engajar em atividades a fim de atingir resultados que valem à pena”.

De acordo com Lawler (1973), a teoria de Vroom, de 1964, foi a única que desenvolveu-se especificamente para o objetivo de lidar com a motivação no ambiente de 
trabalho, e segundo Vroom, a valência (V) refere-se à orientações afetivas para resultados específicos. Um resultado é positivo se a pessoa prefere atingir o objetivo final, neutro se a pessoa é indiferente ou negativo se a pessoa prefere não atingir o objetivo final. $\mathrm{O}$ valor dessa valência pode variar de $-1 \mathrm{a}+1$ : os resultados máximos positivos valem +1 , os máximos negativos, -1 , e os neutros valem 0 . Vroom enfatiza que o valor da valência refere-se à recompensa antecipada do resultado ao invés do valor da recompensa do resultado atual quando obtida.

A expectativa (E) refere-se a uma crença monetária sobre a probabilidade de que um ato em particular terá como conseqüência um determinado resultado, ou seja, a expectativa é vista por Vroom como uma associação de uma resposta de resultado. A expectativa pode ser descrita por meio de sua "força": força máxima, designada pelo número 1, é a certeza subjetiva de que o comportamento será seguido por um resultado; força mínima, designada pelo número 0 , é a certeza subjetiva de que o comportamento não será seguido pelo resultado (LAWLER, 1973).

Assim como outros autores da teoria da expectativa, Vroom argumenta que a expectativa e a valência se multiplicam a fim de determinar a motivação, ou força. $\mathrm{O}$ aspecto multiplicativo dessa teoria é importante, pois significa que a menos que haja valência ou expectativa presentes em qualquer grau, não haverá força alguma. Como pode ser observado na figura 4, se o valor de uma delas for 0 (zero), então não haverá motivação, esta terá o valor 0 (zero). Por exemplo, se um indivíduo quer ter um bom desempenho, mas não sente que seu esforço terá um bom resultado, ele não terá motivação para que isso aconteça, efetivamente (LAWLER, 1973). 


\begin{tabular}{|c|c|c|c|c|c|c|}
\hline $\begin{array}{c}\text { Força } \\
\text { Motivacio } \\
\text { nal }\end{array}$ & $=$ & $\begin{array}{l}\text { Expectativa: } \\
\text { (quão bem a } \\
\text { pessoa } \\
\text { acredita que } \\
\text { pode } \\
\text { desempenhar } \\
\text { uma tarefa) }\end{array}$ & $X$ & $\begin{array}{l}\text { Istrumentalidade: } \\
\text { (quão bem a } \\
\text { pessoa acredita } \\
\text { que o desempenho } \\
\text { levará a um certo } \\
\text { resultado) }\end{array}$ & $X$ & $\begin{array}{l}\text { Valência: } \\
\text { (o valor que a } \\
\text { pessoa dá ao } \\
\text { resultado) }\end{array}$ \\
\hline
\end{tabular}

Figura 4. Resumo da Teoria da Expectativa

Fonte: Dubrin, 2003, p.123.

\subsection{PSM E AS TEORIAS MOTIVACIONAIS}

Entender como o PSM se relaciona com algumas dessas teorias motivacionais não deixa de ser necessário, uma vez que o conceito principal desse constructo é a motivação. Sendo assim, o PSM pode ser "classificado", na Teoria da Hierarquia das Necessidades de Maslow, como a necessidade de auto-realização; na Teoria dos dois Fatores de Herzberg: como fator motivador (ou intrínseco). Apesar dessa classificação, Mann (2006) afirma que essas duas teorias não dão suporte suficiente aos gerentes para influenciarem uma melhora nos níveis de motivação dos funcionários. Segundo o mesmo autor, as teorias da Expecativa de Vroom e de Eqüidade de Adams, por se basearem em escolhas racionais, focam muito nos fatores extrínsecos, que não são o foco principal do PSM (MANN, 2006).

Perry, considerando a importância da escolha racional como base do comportamento, quis desenvolver uma teoria motivacional mais inclusiva, em que o comportamento pró-social e o autoconceito do indivíduo seriam influenciados por meio da exposição aos mecanismos de desenvolvimento social das instituições. De acordo com Mann (2006), o mais importante é 
que nenhuma dessas teorias cobrirá a gama de situações possíveis para todos e cada um dos funcionários de uma organização. Dessa forma, uma abordagem contingencial é necessária e a mais adequada, ajustando diferentes soluções para as diferentes situações, obtidas das várias teorias disponíveis.

\subsection{TEORIA DO PSM - PUBLIC SERVICE MOTIVATION}

De acordo com Brewer (2002), a comunidade da administração pública vem acreditando, por muito tempo, que alguns indivíduos possuem uma forte ética de serviço público que os atrai para empregos no governo promovendo atitudes e comportamentos relacionados ao trabalho que vão além do interesse público. Há alguns anos, pesquisadores têm aumentado o foco de seus estudos no constructo de PSM - Public Service Motivation. Alguns estudos teóricos têm aparecido na literatura e outros empíricos têm ligado o PSM com vários assuntos vitais para a administração pública. Esses assuntos incluem motivação no trabalho, produtividade no setor público, melhoria nas práticas em organizações públicas, entre outros.

Além disso, o PSM possui implicações que vão além da administração pública e que são relevantes para a conduta de políticos e de políticas públicas de uma sociedade democrática. O PSM possui implicações sociais, uma vez que muitas pessoas fora do governo possuem fortes motivos que os levam a desempenhar um trabalho público significativo, comunitário e social (BREWER, 2002). 
Um dos primeiros estudos sobre ética no serviço público foi o de Buchanan (1975, apud BREWER; SELDEN; FACER, 2000)5 . Posteriormente, vários autores deram contribuições significativas para a área: Rainey (1982), Perry e Wise (1990), Wittmer, (1991), Gabris e Simo (1995, apud BREWER; SELDEN; FACER, 2000) ${ }^{6}$,Crewson, (1997), Crewson e Guyot (1997), Perry (1996, 1997), Brewer e Selden (1998). No geral, surgiram basicamente duas correntes empíricas de pesquisa (BREWER, 2000): na primeira corrente, a maioria das pesquisas examinou diferenças entre funcionários dos setores público e privado com as dimensões relacionadas ao PSM, tais como preferências por recompensa financeira, significado de serviço público, comprometimento e satisfação no trabalho; a segunda corrente focou em capturar e explicar as dimensões multifacetadas do PSM.

Rainey (1982) foi um dos pesquisadores pioneiros e deu uma contribuição fundamental quando desenvolveu um estudo com gerentes dos setores público e privado. Ele fez uma pergunta direta a estes gerentes (para ele, seria a melhor maneira de ter acesso aos reais motivos): que "ranqueassem" seu desejo de se engajar em um serviço público significativo. Os resultados mostraram que os gerentes do setor público obtiveram pontuações maiores do que os gerentes do setor privado.

Entretanto, Rainey (1982) detectou diversos problemas no modo como realizou essas perguntas, pois os respondentes poderiam dar respostas socialmente desejáveis ao invés de respostas reais. Além disso, os gerentes do setor privado podem ter boas intenções e simpatizarem-se com o serviço público, mas possivelmente podem não associar essas atividades como um trabalho, um emprego, como o que eles próprios desempenham (BREWER, 2002). Portanto, a contribuição de Rainey para o próximo estágio de pesquisas foi

\footnotetext{
${ }^{5}$ BUCHANAN, B. II. Red Tape and the service ethic. Administration and Society, 6 (4), p. 423-444, 1975. ${ }^{6}$ GABRIS, G. T., SIMO, G. Public Sector Motivation as an independent variable affecting career decisions. Public Personnel Mangement, 24 (1), p. 33-51, 1995.
} 
sua conclusão de que o PSM é "um conceito amplo, multifacetado que varia no tempo, se modifica com a imagem do governo público vigente e toma diferentes formas em diferentes áreas de serviço” (RAINEY, 1982, p. 299).

Wittmer (1991) e Gabris e Simo (1995, apud BREWER; SELDEN; FACER, 2000) estenderam as pesquisas que anteriormente eram realizadas somente nos setores público e privado para os setores híbrido e não-governamental. Os resultados de Wittmer demonstraram que os funcionários dos setores híbrido e não-governamental valorizavam o serviço comunitário e a ajuda ao próximo mais do que os funcionários do setor privado, que valorizavam mais as recompensas financeiras e a segurança. Os resultados de Simo, ao contrário, demonstraram que não houve diferenças na percepção de necessidade por ajudar, pagamento ou segurança, entre os funcionários dos setores público, privado e nãogovernamental estudados por ela (BREWER, 2000).

O que vale destacar dessas duas pesquisas é que havia um problema iminente de medida das dimensões do PSM, o que ficava claro na apresentação contraditória dos resultados obtidos. Rainey (1982) observou que definir e medir o PSM é difícil pela complexidade da natureza de seu constructo.

Perry e Wise (1990, p. 368) seguiram o trabalho de Rainey definindo PSM como " $a$ predisposição do indivíduo em responder a motivos estabelecidos primeiramente ou unicamente em organizações ou instituições públicas”. Eles descreveram três bases potenciais para esses motivos:

* Racionais: os motivos são estabelecidos por interesses próprios. O indivíduo acredita que seu interesse pessoal coincide com o de toda a comunidade. Essa base pode levar o indivíduo a participar de processos políticos, demonstrar comprometimento com 
programas ou políticas públicas pela sua identificação com elas, ou se tornar defensor de algum interesse específico.

* Afetivos: os motivos são estabelecidos nas emoções humanas, e são caracterizados pela vontade e desejo de servir aos outros.

* Normativos: os motivos são estabelecidos pelo envolvimento e dedicação a uma causa e a um desejo de servir ao interesse público, desde que isso seja percebido. Esses motivos incluem patriotismo, dever e lealdade ao governo.

Um detalhe muito importante a ser destacado é que essas categorias podem se sobrepor, não necessariamente acontecendo separadamente todo o tempo. Os autores, então, formularam algumas hipóteses para futuras pesquisas:

* Quanto melhor for o PSM do indivíduo, mais ele buscará se tornar membro de uma organização pública.

* Em organizações públicas, o PSM está relacionado positivamente com desempenho (performance).

* Organizações públicas que atraem indivíduos com alto PSM tendem a ser menos dependentes de incentivos utilitários a fim de melhorar a eficiência do desempenho do indivíduo. 


\subsubsection{A construção do instrumento de medida de PSM}

Perry (1996) iniciou, então, um esforço pioneiro no sentido de construir uma escala de medida para o PSM. Ele transferiu os conceitos da literatura para uma escala de medida.

Há três bases teóricas para o PSM constituída das seguintes categorias: motivos racionais, motivos baseados em normas e motivos afetivos. O estudo de Perry e Wise (1990)

relacionou essas bases com afirmativas que posteriormente, no estudo de Perry (1996) baseariam a construção do instrumento de medida do PSM (quadro 3).

\section{Quadro 3. Categorias da base teórica}

\begin{tabular}{|c|l|}
\hline Motivos & \multicolumn{1}{|c|}{ Afirmativas } \\
\hline \multirow{2}{*}{ Racional } & $\begin{array}{l}\text { Participação no processo de formulação de políticas públicas } \\
\text { Comprometimento com um programa público por identificação pessoal } \\
\text { Apoio a um interesse específico ou pessoal }\end{array}$ \\
\hline \multirow{3}{*}{ Baseado em normas } & $\begin{array}{l}\text { Desejo de servir ao interesse público } \\
\text { Lealdade ao dever e ao governo como um todo } \\
\text { Eqüidade social }\end{array}$ \\
\hline \multirow{2}{*}{ Afetivo } & $\begin{array}{l}\text { Comprometimento com um programa por convicção de que ele é importante } \\
\text { socialmente } \\
\text { Patriotismo Benevolente }\end{array}$ \\
\hline
\end{tabular}

Fonte: Adaptado de Perry e Wise, 1990, p. 370.

As dimensões do PSM foram formuladas a partir da literatura americana sobre ética no serviço público, com a contribuição de conceitos de diversos autores, citados por Perry (1996) em seu estudo de desenvolvimento do instrumento de medida. As dimensões são, portanto, conceituadas como: 
* Formulação de políticas públicas: segundo Kelman (1987, apud Perry, 1996, p.6) ${ }^{7}$, o motivo racional que leva o indivíduo ao serviço público é a oportunidade que ele tem de participar da formulação de políticas públicas. A atração pela formulação de políticas públicas pode influenciar a imagem do indivíduo, no sentido de ele se achar importante (PERRY, 1996).

Comprometimento com o interesse público: um dos fundamentos mais comuns de se encontrar na literatura sobre o serviço público é o de comprometimento com o interesse público. Segundo Perry (1996), Dows argumenta que o desejo de servir ao interesse público é essencial.

* Dever cívico: O único valor do constructo de Public Service Motivation sempre presente é o desejo de servir ao interesse público. Buchanan (1975, apud Perry, 1996, p.7) afirma que o PSM evolve um senso de dever cívico único.

* Justiça social: envolve atividades intencionadas para melhorias no bem-estar das minorias que se encontram desprovidas de recursos políticos e econômicos. Frederickson (1971, apud Perry, 1996, p.7 $)^{8}$ argumenta que a obrigação dos administradores públicos é prover serviços de forma eficiente enquanto melhora a eqüidade social. Esse mesmo autor sugere que a inclusão da eqüidade social entre os valores dos administradores públicos ajuda a definir a natureza política dos papéis dos mesmos.

* Compaixão: Frederickson e Hart (1985) sugerem que o principal motivo para servidores civis é o que eles chamam de "patriotismo benevolente", definido como o amor das pessoas para com os limites políticos e da necessidade de serem protegidos em todos os seus direitos básicos. Perry (1996) chama de compaixão o termo citado

\footnotetext{
${ }^{7}$ KELMAN, S. Public choice and public spirit. Public Interest, 87 (spring), p. 80-94, 1987.

${ }^{8}$ FREDERICKSON, H. G. Toward a new public administration: the minnowbrook perspective. Scranton, $p$. 309-331, 1971.
} 
acima. Apesar dos primeiro autores afirmarem que este "patriotismo benevolente" representa uma posição moral, ela também pode ser entendida como um estado emocional.

* Auto-sacrificio: sexto e último motivo freqüentemente associado ao serviço público; refere-se ao desejo de substituir a recompensa material pelo serviço prestado ao próximo. Um exemplo dado por Perry (1996) é de uma frase dita pelo presidente Kennedy e que segundo o autor, ilustra bem esse conceito: "Não pergunte o que o seu país pode fazer por você e sim o que você pode fazer pelo seu país".

Assim como Perry e Wise (1990) relacionaram afirmativas com as categorias de base teórica, após o trabalho de construção do instrumento de medida do PSM, a relação entre as dimensões e essas categorias de base teórica também podem ser relacionadas da seguinte maneira (quadro 4):

\section{Quadro 4. Relação das dimensões do PSM com as categorias da base teórica.}

\begin{tabular}{|c|l|}
\hline Motivos & \multicolumn{1}{c|}{ Dimensões } \\
\hline Racional & Formulação de políticas públicas \\
\hline Baseado em normas & $\begin{array}{l}\text { Comprometimento com o interesse público, Dever } \\
\text { Cívico, Justiça Social }\end{array}$ \\
\hline Afetivo & Compaixão, Auto-sacrifício \\
\hline
\end{tabular}

Do esforço inicial de desenvolver uma escala de medida para o PSM surgiu um constructo multidimensional fundamentado na teoria de administração pública. A escala de medida foi desenvolvida por meio de uma análise fatorial confirmatória, derivando quatro dimensões das seis primeiras citadas anteriormente: formulação de políticas públicas, interesse público, compaixão e auto-sacrifício. Os três primeiros fatores estão relacionados com as três bases teóricas propostas por Perry e Wise (1990) e o último fator está relacionado com sua freqüente menção na literatura correspondente (PERRY, 1996). 
É relevante, neste ponto, uma observação sobre as categorias de base teóricas propostas por Perry. A base afetiva proposta por ele vai ao encontro do conceito de "vocação" de Lutero, que Weber traz em seu livro “A Ética Protestante e o Espírito do Capitalismo”. Ele coloca que os protestantes eram herdeiros de grande riqueza material, mas mais do que isso, sua educação era rigorosamente oposta à dos católicos. Enquanto no protestantismo os estudos eram direcionados para trabalhos técnicos e especializados, no catolicismo os estudos se voltavam para a humanidade. A idéia de vocação surge, então, como o elo entre a ética protestante e o "espírito do capitalismo" que originou o aparecimento do racionalismo ocidental.

Esse conceito é contrário a esse racionalismo, pois tem um significado de plano de vida, de uma dedicação a uma área de trabalho, como se fosse uma missão: “A vocação é aquilo que o ser humano tem de aceitar como desígnio divino, ao qual tem que "se dobrar" essa nuance eclipsa a outra idéia também presente de que o trabalho profissional seria uma missão, ou melhor, a missão dada por Deus. ", (WEBER, 1920, p. 77).

Assim, quando Perry afirma que a base afetiva é orientada pelas emoções, pelo desejo de servir aos outros, percebe-se uma congruência com o conceito de vocação que Weber descreve. Uma vez que no trabalho de pesquisa de Perry (1997) sobre os possíveis antecedentes do PSM uma das dimensões estudadas é a Socialização Religiosa, essa congruência entre os conceitos pode deixar de ser mais do que simples semelhança para talvez se tornar um dos fundamentos que origina a teoria do PSM.

\footnotetext{
9 'Não há dúvida de que já na palavra alemã 'Beruf', e, quem sabe, ainda mais, na palavra inglesa 'calling', existe um conotação religiosa - a de uma tarefa ordenada, ou pelo menos sugerida por Deus - que se torna tanto mais manifesta, quanto maior for a ênfase do caso concreto. Haja vista a trajetória histórica da palavra, através dos idiomas civilizados(Kultursprachen), nos quais se nota imediatamente que, para aquilo que hoje chamamos de 'vocação' (no sentido de um plano de vida, de uma determinada área de trabalho), nem os povos predominantemente católicos, nem a Antigüidade Clássica conheceram um termo equivalente, ao mesmo tempo que ele tem existido entre todos os povos predominantemente protestantes"(Weber, 1920, p. 71).
} 


\subsubsection{Possíveis fatores antecedentes do PSM}

Dando seguimento aos seus estudos, Perry (1997) identificou alguns antecedentes do PSM e reportou sua correlação com a escala de medida, provando, portanto, a evidência da validade deste constructo. Estes antecedentes são: socialização familiar, socialização religiosa, identidade profissional, ideologia política e características demográficas individuais. Perry (1997) coloca ainda que experiências educacionais e socialização organizacional também ajudam a afirmar o PSM.

O constructo ainda é novo, e não há nenhum outro análogo na literatura de administração pública. Porém, fontes potenciais podem ser pesquisadas e identificadas, como, por exemplo, as dimensões do PSM (atração pela formulação de políticas públicas, comprometimento com o interesse público, compaixão). $\mathrm{O}$ estudo inicial desses antecedentes não objetiva explorar todas as possibilidades existentes, e sim enfatizar alguns fatores que sejam plausíveis e correlacionados ao PSM. Abaixo, segue a descrição de cada um dos fatores considerados como possíveis antecedentes do Public Service Motivation (PERRY, 1997):

Socialização familiar: o primeiro contexto de socialização considerado na sociedade americana é o da família, particularmente, os pais. Algumas pesquisas mostram que há relação entre experiências na fase da infância e o comportamento altruístico na fase adulta. Rosenhan (1970, apud Perry, 1997, p. 183) ${ }^{10}$ identificou fontes para diferentes níveis de altruísmo em indivíduos que trabalhavam com direitos civis. Uma dessas fontes foi o relacionamento afetivo dessa pessoa com pelo menos um dos pais. Quanto mais

\footnotetext{
${ }^{10}$ ROSENHAN, D. The natural socialization of altruistic autonomy. In: MACAULAY, J., BERKOVITZ, L. Altruism and helping behavior. New York: Academic Press, 1970.
} 
positivo foi o relacionamento da pessoa com os pais, maiores foram os níveis de altruísmo que a pessoa demonstrou. O exemplo de comportamento de altruísmo dos pais foi outra fonte influenciadora desse comportamento em crianças na sua fase adulta (PERRY, 1997). Duas dimensões do PSM podem ser relacionadas com altruísmo: compaixão e autosacrifício; portanto, elas podem ser provenientes da socialização familiar.

Socialização religiosa: outra influência importante no PSM é a experiência e a vivência religiosa do indivíduo. A religião é uma instituição na qual os indivíduos desenvolvem crenças sobre suas obrigações para com os outros e provê a oportunidade de colocar em prática essas crenças. Estas estão diretamente relacionadas com algumas das dimensões do PSM, especificamente com o comprometimento com o interesse público, dever cívico e compaixão. Indivíduos que possuem uma visão de mundo individualista tendem a apresentar baixos níveis de PSM, ao contrário dos que possuem uma visão mais humanitária (PERRY, 1997).

* Identidade Profissional: a profissão é outra variável que influencia o PSM. Historicamente, as profissões têm sido receptoras de valores provenientes do serviço público, como por exemplo, a medicina e o direito, que propagam de certa forma os valores de justiça social e de bem comum (PERRY, 1997). Provavelmente a tensão entre o interesse profissional pessoal e o ideal de profissional responsável ética e moralmente é o que compele um maior ou menor grau de influência do profissionalismo no PSM.

* Ideologia Política: as crenças que os indivíduos adquirem de suas afiliações políticas também são consideradas como antecedentes do PSM. Apesar dos partidos políticos americanos não se organizarem em bases ideológicas, historicamente eles sempre tomaram posições distintas com relação ao papel do Estado. Essas diferenças ideológicas ficaram mais distintas somente há alguns anos. Crenças políticas devem basear-se no PSM (PERRY, 1997). 
- Características individuais demográficas: primeiramente com o propósito de controle, foram inseridas algumas variáveis demográficas na análise: educação, idade e renda (PERRY, 1997).

O objetivo de Perry (1997) com esse estudo foi testar algumas proposições sobre os antecedentes do PSM. Os resultados sugeriram que um indivíduo desenvolve uma motivação para o serviço público devido a exposição à várias experiências, algumas relacionadas com a infância, outras com religião e outras com a vida profissional. Os coeficientes de regressão dos cinco modelos testados foram muito pequenos (de 0,18 a 0,07 ), o que indica que as variáveis utilizadas estão longe de explicar de forma precisa a variação do PSM. Porém, os modelos de regressão identificaram alguns fatores que afetam de forma significativa o PSM (PERRY, 1997):

Identidade Profissional: essa variável é negativamente correlacionada com a atração por formulação de políticas públicas.

* Envolvimento com a igreja: o resultado foi também contrário do esperado. A possível explicação seria a de que o envolvimento com a igreja na verdade é um conjunto de variáveis, tais como fundamentos religiosos (diferentes religiões geram comportamentos diferentes com relação ao PSM), tempo gasto em atividades da igreja (pouco tempo livre para o comprometimento com deveres civis), entre outros que não foram inclusos no estudo.

- Os resultados para a variável renda foram os menos esperados, uma vez que se verificou que quanto maior a renda do indivíduo, menor é sua motivação com relação ao interesse público/dever cívico. Há uma crença de que indivíduos com alta renda geralmente se envolvem no serviço público, como se estivessem retribuindo por tudo o 
que conseguiram. No cenário descrito por Lasch (1995, apud Perry, 1997, p.192) ${ }^{11}$, a elite americana abandonou seu comprometimento histórico com a classe média, tornando-se cidadãos do mundo, à parte da prática da cidadania.

Perry (1997) conclui, então, que esse estudo foi apenas o primeiro de vários que devem ser desenvolvidos a fim de identificar os antecedentes do PSM. Os resultados demonstraram que o PSM é relacionado a diversas variáveis, muitas não identificadas e outras relacionadas de forma mais ou menos complexas com o PSM.

${ }^{11}$ LASCH, C. The revolt of the elities and the betrayal of democracy. New York: Norton, 1995. 


\section{CAPÍTULO 3 - MOTIVAÇÃO, PSM E COMPROMETIMENTO}

Como discutido anteriormente, as constantes mudanças no ambiente organizacional (privado ou público) criaram a necessidade de repensar antigos pressupostos administrativos. No setor público, a situação é mais urgente, uma vez que as organizações lutam contra a ineficiência da máquina (ainda) burocrática do governo, apesar do esforço empreendido nas reformas do Estado. O fator humano é ao mesmo tempo essencial e ponto crítico nesse contexto, pois há uma necessidade de servidores motivados e comprometidos, a fim de melhorar a eficiência e produtividade do setor.

Assim, o presente estudo utilizará no processo de validação da escala do PSM o constructo de comprometimento, uma vez que estudos (PEREIRA; OLIVEIRA, 2000, BREWER; SELDEN, 1998, MORAES, 2005, PERRY; WISE, 1990, ROMZEK, 1990, LIOU; NYHAN, 1994) demonstram a relação existente entre este contructo e motivação.

Mais especificamente, o trabalho de Romzek (1990) enfatiza a importância de identificar as dimensões específicas da motivação dos funcionários e seu comprometimento. Segundo a autora, há dois tipos de envolvimento psicológico do funcionário com a organização: um baseado nos investimentos realizados pelo indivíduo em seu local de trabalho e outro baseado em um comprometimento com os valores compartilhados da organização.

O estudo de Liou e Nyhan (1994) sobre comprometimento organizacional no setor público baseou-se nas sugestões de Romzek (1990) e Perry e Wise (1990) de que o comprometimento organizacional é a chave para o aumento da motivação no serviço público e que mais estudos empíricos sobre o comprometimento do servidor são necessários para se 
entender melhor quais são suas bases motivacionais nessas organizações. Em sua pesquisa, utilizaram, então, a escala de Meyer e Allen (1991) de Comprometimento Afetivo (ACS Afective Commitment Scale) e de Comprometimento Instrumental (CCS - Continuance Commitment Scale) por dois motivos: primeiro porque eles consideravam esse questionário apropriado para estudar os argumentos teóricos entre as abordagens atitudinal e comportamental e segundo porque ele examina diretamente o argumento de Romzek de que o investimento e o comprometimento com os valores da organização fazem com que o funcionário seja mais comprometido (LIOU; NYHAN, 1994). Romzeck (1990) argumenta ainda que o comprometimento entre servidores públicos também pode ser considerado um meio de alcançar um PSM efetivo.

Segundo Brewer e Selden (1998), alguns comportamentos organizacionais são importantes a fim de se entender o conceito de PSM e a literatura sugere que, quando o PSM é efetivo, os funcionários são mais produtivos, valorizados e comprometidos com as organizações em que trabalham.

As publicações sobre comprometimento nos EUA tiveram um aumento significativo nas décadas de 1970 e 1980 (PEREIRA; OLIVEIRA, 2000). Bastos (1995) observa, em suas pesquisas, duas principais vertentes: 1) como o indivíduo organiza suas tarefas frente às diferentes facetas da organização (que passa a ser vista mais como grupo, trabalho, projetos do que como um todo) e 2) explora os processos psicológicos do vínculo do indivíduo com a organização (vista como um todo).

Assim, comprometimento organizacional é conceituado por Bastos (1995, p.46) como uma "adesão, um forte envolvimento do indivíduo com variados aspectos do ambiente de trabalho". 
Medeiros e Enders (1998) validaram o modelo (de 18 itens) de conceitualização de três componentes do comprometimento organizacional proposto por Meyer e Allen (1991). Segundo Medeiros (2003), esse modelo é internacionalmente aceito, tendo sido validado em diversas culturas (no Brasil, foi validado por Medeiros, no ano de 1997), e é composto dos seguintes elementos:

* Comprometimento afetivo: comprometimento como um apego, ocorrendo uma identificação com a organização;

* Comprometimento instrumental: comprometimento percebido como custos associados a deixar a organização;

* Comprometimento normativo: comprometimento como uma obrigação de permanecer na organização. 


\title{
CAPÍTULO 4 - O SERVIÇO PÚBLICO NO BRASIL
}

Este capítulo descreve, resumidamente, períodos da Reforma do Estado, a fim de contextualizar a realidade do Brasil no que diz respeito ao funcionamento e regulamentação do seu serviço público.

De acordo com Couto (1998), o Brasil enfrentou um grande desafio em seus processos de transição: realizar reformas e consolidar suas democracias, simultaneamente. A Nova República e a Constituição de 1988 contribuíram sobremaneira no que diz respeito à consolidação de sua democracia, mas, infelizmente criaram muitas outras barreiras para a implementação das reformas:

\begin{abstract}
A construção do Estado nacional-desenvolvimentista no país se deu em contexto autoritário, sob a ditadura do Estado Novo; a primeira grande reforma desse modelo ocorreu sob os militares, com o Decreto-lei $\mathrm{n}^{\circ} 200$, de 1967, e por outras medidas que não enfrentaram os trâmites do sistema representativo. Mesmo dispositivos institucionais importantes em tempos democráticos, criados no governo Juscelino Kubitschek para permitir um salto no processo substitutivo de importações - os Grupos Executivos e Grupos de Trabalho Setoriais - foram, antes, formas de burlar os obstáculos formais do sistema democrático do que instrumentos a ele incorporados (COUTO, 1998, p. 18).
\end{abstract}

Uma das crises por que passou o aparelho estatal se agravou a partir da Constituição de 1988, quando passa do clientelismo e da profissionalização incompleta para o enrijecimento burocrático extremo. A conseqüência foi a ineficiência e a má qualidade da administração pública central e dos serviços sociais do Estado. A Constituição sacramentou os princípios de uma administração pública arcaica e burocrática, altamente centralizada, 
hierárquica, rígida, fundamentalmente baseada na idéia do controle por processo e não por resultados e objetivos, quando a base da administração pública moderna é a descentralização, a administração matricial, os sistemas de autoridade funcional convivendo com os de linha, na confiança, e no controle dos resultados e não dos processos (PEREIRA, 1995).

A burocracia que Max Weber descreveu foi adotada como alternativa para a administração patrimonialista do Estado, porque era a melhor forma de reduzir o empreguismo, o nepotismo e a corrupção existentes até então. Apesar da "boa intenção", percebeu-se que, se era uma maneira segura de administrar, não era uma forma eficiente, já que não garantia nem um custo baixo para a administração pública nem uma qualidade adequada dos serviços prestados ao público (PEREIRA, 1995).

A partir de 1995, a proposta do Governo para a Reforma do Estado defende o modelo gerencial e critica o modelo burocrático que estaria baseado no controle de processos e na busca de efetividade e eficácia das decisões. A Reforma Administrativa por meio da Emenda Constitucional $n^{\text {o }}$ 19/98, afeta a relação Estado-Servidor Público, principalmente quanto a: flexibilização dos regimes (formas de Ingresso), estabilidade, sistema de remuneração, disponibilidade, redução dos quadros para adequação de despesas (ASSEMBLÉIA LEGISLATIVA DO ESTADO DE SÃO PAULO, 1999). 


\subsection{O serviço público}

O serviço público tem sido pensado nos governos nacionais dos países latinoamericanos numa perspectiva de consolidação de uma burocracia independente que possa garantir a estabilidade no processo de elaboração das políticas públicas. Autores como Spiller, Stein e Tommasi (2003), Alston, Melo e Mueller (2005) e Pereira (2004), atribuem um importante papel ao serviço público organizado, uma vez que este pode colaborar para a efetividade das políticas e um antídoto contra decisões que priorizem questões de curto prazo.

A atividade pública foi associada à ineficiência e à possibilidade de corrupção e chegou-se a um desprestígio extremo da figura do servidor, a ponto destes serem considerados como um dos maiores obstáculos para o progresso. Em nome dessa redução, alguns países destruíram a moral do serviço público quando criaram um clima de incerteza contínua aos servidores, quando realizaram cortes ou minimizaram incentivos utilizando critérios arbitrários, criando incentivos para demissões voluntárias. O resultado dessas práticas foi a perda dos profissionais mais qualificados e da "massa crítica" das organizações públicas (KLIKSBERG, 2005).

Segundo Pereira (2002), o Brasil foi um dos poucos países latino-americanos que empreendeu uma reforma completa do serviço público: o DASP (Departamento Administrativo do Serviço Público - a agência brasileira que ficou a cargo da reforma), em 1936. Foi a primeira reforma e estabeleceu um serviço público profissional e os princípios da administração pública burocrática, mas nunca foi terminada. A segunda reforma foi estabelecida pelo regime militar por meio do decreto-lei número 200 do ano de 1967, mas foi interrompida em 1988, com o retorno à democracia. A terceira reforma, no ano de 1995 é, na 
verdade, uma contra-reforma, incorporada na Constituição de 1988, que tentou estabelecer ou restabelecer regras burocráticas rígidas dentro do Estado brasileiro.

O serviço público, após ter sofrido vários embates nas décadas anteriores, passou a ser visto como uma estratégia para a transformação do Estado. No Brasil, a reforma da administração pública com o MARE - Ministério da Administração e Reforma do Estado, em 1995, teve como objetivo fortalecer a governança, por meio da transição de uma administração burocrática para uma administração gerencial, ou seja, o Estado caracterizado anteriormente como rígido e ineficiente agora se tornaria flexível e eficiente, com foco no atendimento à cidadania. Esse esforço se estendeu também à gestão dos recursos humanos, que nesse novo contexto, requeria um sistema de administração radicalmente diferente, a fim de acomodar as mudanças propostas e que aprofundassem o comprometimento com os valores permanentes que protegem o interesse público (MARE, 1997). A execução da reforma continua sob a responsabilidade do Ministério do Planejamento, Orçamento e Gestão (que surgiu da incorporação do MARE ao Ministério do Planejamento) (PEREIRA, 2002).

Neste contexto, os servidores devem ser capacitados para analisar problemas socioeconômicos e competentes para buscar as soluções demandadas pela sociedade (SOUZA, 2002). Sendo assim, a profissionalização e a valorização do servidor público foi um dos fatores que passaram a fundamentar a Reforma do Estado proposta pelo MARE, e a adequação da gestão de recursos humanos foi um dos pontos prioritários no contexto dessa mudança. Essa nova política envolveu a captação de novos servidores, o desenvolvimento de pessoal, a implantação de um sistema remuneratório que estimulasse o desempenho dos servidores por meio de incentivos e a reorganização de cargos e carreiras (MARE 1997). 


\subsection{Emprego Público}

Emprego público é a relação empregatícia estabelecida pelo poder público no regime da CLT - Consolidação das Leis do Trabalho e legislação trabalhista correlata. A Lei 9.962, de 22.2.2000, regula a matéria da área federal (FUHRER; FUHRER, 2006, p.84).

Segundo os mesmo autores, a contratação é realizada por concurso público e a despedida pode acontecer devido a quatro fatores:

* Falta grave;

Acúmulo ilegal de cargos, empregos ou funções públicas;

* Necessidade de redução de quadro de pessoal, por excesso de despesa, de acordo com regulamentação respectiva;

Insuficiência de desempenho, também de acordo com regulamentação respectiva.

\subsection{Servidores Públicos}

Alguns termos são utilizados para definir quem trabalha no serviço público, como, por exemplo, funcionário público e servidor público. Segundo Spitzcovsky (2005), termos como esses restringem o universo de pessoas inseridas no contexto da Administração Pública e, sendo assim, sugere a expressão “agentes públicos”. Essa expressão engloba os funcionários públicos (que titularizam cargos públicos), empregados públicos (que titularizam empregos públicos), os contratados em caráter temporário e os particulares em colaboração com o 
Estado (não ocupam cargos ou empregos públicos, mas de alguma forma exercem serviços públicos) (SPITZCOVSKY, 2005).

Assim, Nohara (2006) coloca a seguinte classificação para as servidores públicos:

Servidores estatutários: sujeitos ao regime estatutário e ocupantes de cargos públicos;

Empregados públicos: contratados sob o regime da legislação trabalhista, mas que mesmo estando sujeitos à CLT - Consolidação das Leis do Trabalho, submetem-se a todas as normas constitucionais referentes;

Servidores temporários: contratados por um tempo previamente determinado a fim de atender a necessidades temporárias de interesse público.

\subsection{Cargo, emprego ou função}

No âmbito federal (Lei número 8.112/90, do regime jurídico único), o servidor que ocupa um cargo público é regido pelo estatuto dos funcionários públicos. Para atribuições pautadas em vínculo contratual, é designado o emprego público, regido pela CLT. Já os empregados públicos são os servidores que se sujeitam a um regime jurídico híbrido, ou seja, um regime celetista, mas com normas de direito privado, mas, contudo, parcialmente regido por normas do direito público (NOHARA, 2006). A EC - Emenda Constitucional 19, de 4.6.98 suprimiu o regime único para os servidores públicos, e a Constituição passou, então, a admitir a convivência entre os sistemas celetista e estatutário (FUHRER; FUHRER, 2006) .

“A função pública é uma tarefa. Todos os cargos têm uma função, mas nem todas as funções decorrem de um cargo" (FUHRER; FUHRER, 2006, p. 75). 


\subsection{Sistemas Remuneratórios}

O regime de remuneração sofre profundas modificações a partir da Emenda Constitucional $n^{0}$. 19/98. A partir de então, há dois sistemas de remuneração dos servidores (NOHARA, 2006; FUHRER; FUHRER, 2006):

O da remuneração ou vencimento: uma remuneração fixa e uma variável composta de vantagens pecuniárias variáveis (adicionais por tempo de serviço, por função, gratificações de serviço, de representação ou pessoais);

* O do subsídio: constituído de parcela única, sem qualquer acréscimo (remuneração única de membros do poder).

Spitzcovsky (2005) enfatiza também as vantagens relacionadas à remuneração, como as gratificações adicionais, licenças e indenizações, cada uma com fato gerador diferenciado, levando também em consideração as diferentes esferas do governo.

\subsection{Aposentadoria}

A aposentadoria do servidor público depende do regime previdenciário a que ele se vincula, sendo que há duas modalidades deste (NOHARA, 2006, p. 140):

Regime geral da previdência social: estabelecido no art. 201 e seguintes da Constituição, igual ao do trabalhador privado, disciplinado pela Lei número 8.212/91; 
Regime previdenciário próprio: próprio do servidor, previsto no art. 40 e disciplinado pela Lei número 9.717/98.

Somente poderão se aposentar nas regras na EC número 41/2003 os servidores que contribuíram em alguma medida para a seguridade social. Os destinatários dessas regras não são todos os servidores públicos, uma vez que as mesmas não aplicam a qualquer um deles, mas somente aos que sejam titulares de cargos efetivos na Administração direta e nas autarquias e fundações ${ }^{12}$. Não são destinatários os servidores que ocupam cargos em sociedades de economia mista e empresas públicas, aplicando-se a estes as regras do regime geral de previdência (SPITZCOVSKY, 2005).

Todos os servidores têm direito à aposentadoria por invalidez, compulsória e voluntária (NOHARA, 2006).

${ }^{12}$ Segundo Spitzcovsky, 2005:

Administração direta: Governos da União, dos Estados e dos Municípios e seus Ministérios e Secretarias.

Autarquias: Entidade de direito público, com personalidade jurídica e patrimônio próprios, destinada à execução de atividades destacadas da administração direta.

Fundações: Pessoa jurídica composta por um patrimônio juridicamente personalizado, destacado pelo seu fundador, para uma finalidade específica. 


\subsection{Estabilidade e Vitaliciedade}

Segundo Fuhrer e Fuhrer (2006), pelo artigo 41 da Constituição Federal, o servidor concursado:

* Adquire estabilidade com os seguintes requisitos: concurso, três anos de cargo efetivo e aprovação de desempenho;

Pode perder o cargo em caso de: sentença judicial transitada em julgado, processo administrativo com ampla defesa, procedimento de avaliação periódica com ampla defesa, excesso de despesa com pessoal da União, dos Estados, do Distrito Federal ou dos Municípios (após esgotadas as medidas prévias).

Os cargos vitalícios asseguram aos seus titulares o direito de permanência neles. Dentre todos os cargos, este é o que possui maior garantia de permanência, pois os servidores somente serão afastados mediante sentença judicial transitada em julgado. São cargos vitalícios os cargos de membros da Magistratura, do Tribunal de Contas e do Ministério Público e são adquiridos após dois anos de exercício do cargo da Magistratura ou do Ministério Público, caso se tenha adentrado mediante concurso público (NOHARA, 2006). 


\subsection{Direitos e deveres}

Com relação ao regime disciplinar, Spitzcovsky (2005, p. 402) relaciona uma série de deveres e proibições (restritas às previsões contidas na legislação federal, uma vez que ela se diferencia nas diversas esferas do governo) segundo a Lei $\mathrm{n}^{\mathrm{o}}$. 8.112/90. O descumprimento de qualquer uma das situações relacionadas abaixo poderá levar a penalização do servidor na forma prevista por essa lei no artigo 127.

Deveres:

Observar as normas legais e regulamentares (inc.III);

Cumprir as ordens superiores exceto quando manifestamente ilegais (inc. IV);

- Guardar sigilo sobre assunto da repartição (inc. VIII);

Ser assíduo e pontual ao serviço (inc. X).

Proibições (art. 117):

* Retirar, sem prévia anuência da autoridade competente, qualquer documento ou objeto da repartição (inc. II);

* Manter sob sua chefia imediata, em cargo ou função de confiança, cônjuge, companheiro ou parente até o segundo grau civil (inc. VIII);

* Valer-se do cargo para lograr proveito pessoal ou de outrem, em detrimento da dignidade de função pública (inc.IX);

* Receber propina, comissão, presente ou vantagem de qualquer espécie em razão de suas atribuições (inc. XII); 
* Utilizar pessoal ou recursos materiais da repartição em serviços ou atividades particulares (inc. XVI).

Com relação aos direitos e vantagens, é garantido ao servidor público civil direito à livre associação sindical, de acordo com o art. 37, VI da Constituição Federal. O direito de greve será exercido nos termos e nos limites definidos em lei específica, que ainda não foi editada, segundo o mesmo artigo citado acima, VII da Constituição Federal (FUHRER; FUHRER, 2006). 


\title{
CAPÍTULO 5 - O SERVIÇO PÚBLICO NOS EUA
}

\author{
Este capítulo descreve, de forma resumida, o funcionamento e a \\ regulamentação do funcionalismo público nos EUA, a fim de contextualizar a realidade desse \\ país no que diz respeito a este tema.
}

\subsection{O serviço público}

Até o ano de 1883, o sistema de pessoal do Governo Federal dos Estados Unidos baseou-se no favoritismo político, ou seja, era pré-requisito para a entrada no serviço público pertencer a algum partido. A Lei Pendleton, do ano de 1883 criou, então, a Comissão de Serviço Civil dos Estados Unidos, que implantaria e gerenciaria um sistema baseado em mérito (RODRIGUES, 1995).

A lei que regulamenta o funcionalismo público nos Estados Unidos não é única e sendo assim, ela se diferencia em alguns aspectos nas esferas Estadual e Municipal. No nível Federal, a lei que regulamenta o sistema de pessoal é o Civil Service Act, ou Lei Pendleton, promulgada em janeiro de 1883. Os benefícios dessa lei atingem tanto os funcionários de carreira como também os que são indicados para cargos de confiança. Inúmeras reformas já foram realizadas nessa lei, sendo que a versão de 1978 é a que vigora até os dias atuais e que continha a criação dos seguintes elementos (RODRIGUES, 1995): 
Escritório de Gerenciamento de Pessoal (Office of Personnel Management);

Conselho de Proteção do Sistema de Mérito (Merit Systems Protection Board);

Autoridade Federal de Relações Trabalhistas (Federal Labor Relations Authority);

* Dispositivos para a proteção de delatores (whistleblowers);

* Um sistema de avaliação de desempenho para aumentar a produtividade e estabelecer um elo entre o desempenho e o pagamento para gerentes federais;

* Sistema de pagamento por mérito para gerentes intermediários;

Serviço de Executivos Sênior (Sênior Executive Service).

A partir das décadas de 70 e 80 o serviço público nos Estados Unidos foi se enfraquecendo lentamente e que a Comissão Nacional do Serviço Público (também conhecida comumente como a Comissão Volcker) chamou de "crise quieta". Esse período ficou marcado pela perda da confiança do povo em seus gestores eleitos e nomeados e por um serviço público "largado" (SONI, 2004).

Desde a década de 90, a administração pública americana vem passando por um processo de mudanças em suas práticas. A idéia principal que orienta essas mudanças se refere às novas práticas que procuram utilizar como modelo a abordagem do setor privado e de negócios no setor público. Foi no governo Clinton, com a Revisão Nacional de Desempenho (Nacional Performance Review) que iniciaram-se várias reformas e projetos. Esse novo desenho da administração pública mexeu muito com a nação. A aplicação dessas idéias girava em torno de um tema comum: os mecanismos do mercado e sua terminologia (DENHARDT; DENHARDT, 2000).

Denhardt e Denhardt (2000, p. 551) diferenciam a "Nova Administração Pública" ou o que eles chamam de "Novo Serviço Público" da "Antiga Administração Pública” por meio de um modelo de idéias que são associadas à antiga administração pública: 
* O foco do governo é a entrega direta de serviços; a melhor estrutura organizacional é a burocracia centralizada;

Programas são implementados por meio de mecanismos de controle do topo para baixo, limitando a autonomia o máximo possível;

* A burocracia tende a ser um sistema o mais fechado possível, limitando, assim, o envolvimento do cidadão;

* Eficiência e racionalidade são os valores mais importantes em organizações públicas;

* Os administradores públicos não possuem um papel central na formulação de políticas e governança; ao invés disso, eles são encarregados da implementação eficiente de objetivos públicos.

Mais do que a simples implementação de novas técnicas, a Nova Administração Pública apresenta um novo conjunto de valores baseando-se no setor privado.

Por diferentes motivos, essa crise continuou durante a década de 90 e ainda perdura. Segundo Soni (2004), a crise baseia-se principalmente no grande número de servidores públicos que irão se aposentar nos próximos anos sem que haja pessoas mais jovens para substituí-los. Além disso, as agências se encontram com um número bem menor do que o ideal de funcionários, sem líderes seniores e sem supervisores bem treinados.

Essas preocupações são reforçadas pelo relatório preliminar da Segunda Comissão Nacional do Serviço Público que apresenta um cenário pessimista de crise. Light (2002 apud SONI, 2004, p.158) ${ }^{13}$ coloca que "Os Estados Unidos não podem vencer o terrorismo ou reconstruir a segurança do país sem uma dedicação total do serviço público federal”. O atentado de 11 de setembro fez com que o governo se desestabilizasse, perdendo força nas

${ }^{13}$ LIGHT, P. C. The troubled state of the federal public service. Washington, D.C.: Brooking Institutions, 2002. 
características que Light (2002 apud SONI, 2004, p.158) considera como essenciais para um serviço público forte: (1) motivado pela chance de realizar algo importante representando o país, (2) realizar um recrutamento de pessoal do topo do mercado de trabalho, (3) viabilizar ferramentas e capacidade organizacional para o sucesso, (4) recompensas por um trabalho bem realizado e (5) respeito pelas pessoas e pelos líderes que servem.

\subsection{Servidores Públicos}

Como já citado anteriormente, o sistema predominante em vigor nos EUA é o sistema de mérito. Atualmente, mais de $90 \%$ dos funcionários públicos federais se beneficiam por algum tipo de regime jurídico baseado nesse sistema e desse total, 59\% fazem parte do chamado "sistema competitivo" (ingressaram o serviço público por meio de concurso), 23\% trabalham para os correios e $8 \%$ fazem parte de outro sistema que não o descrito pelo Civil Service Act (RODRIGUES, 1995).

O Escritório de Gerência de Pessoal (OPM - Office of Personnel Management) é o órgão responsável pela aplicação correta da lei, apesar de existirem algumas agências que estabelecem procedimentos específicos. Entre esse tipo de agências, podem ser citadas: os

Correios, o Departamento de Assuntos de Veteranos de Guerra, o Serviço de Saúde Pública dos Estados Unidos e o FBI (OPM, 2004).

Segundo Rodrigues (1995), o processo de recrutamento não sofreu qualquer alteração desde a reforma de 1978. O processo de ingresso por concurso habilita o candidato a ter seu nome inscrito em um registro de candidatos habilitados. As provas podem ser escritas ou práticas ou em forma de uma avaliação do treinamento acadêmico e da experiência do 
candidato ou ainda pode ser uma combinação desses três elementos. Quando uma agência necessita de um candidato, ela entra em contato com a OPM, que efetua uma busca em seu banco de registros e indica os primeiros colocados da lista. Geralmente a escolha fica entre os três primeiros candidatos. Esse processo ocorre dessa forma para que elementos intangíveis (como, por exemplo, traços da personalidade) que não são captados em resultados de provas possam ser identificados.

Há também a opção de ingresso sem o concurso. Entre essas opções, há o caso de contratações para funções temporárias, além de preenchimento de cargos após a primeira efetivação, quer dizer, quando há transferência, promoção ou redesignação do cargo. Mesmo não passando pelo processo de concurso, o indivíduo deve preencher os requisitos da OPM, além de ter que passar por uma avaliação de desempenho realizada pela agência contratante (RODRIGUES, 1995).

\subsection{Sistemas Remuneratórios}

A Constituição dos Estados Unidos exerce um controle sobre o Congresso e no que diz respeito à remuneração dos funcionários federais e este controle se dá por meio de leis, políticas, princípios e procedimentos a fim de estabelecer valores para os sistemas de remuneração. Os funcionários federais são regidos por diferentes meios sendo que alguns são estabelecidos por leis individuais e alguns por determinação administrativa. O Sistema Legal

de Remuneração ${ }^{14}$ (Statutory Pay System) e os Sistemas Principais de Remuneração ${ }^{15}$ (Major

14 Tradução da autora.

${ }^{15}$ Idem. 
Pay System) são os dois grandes principais sistemas em vigor e podem ainda ser subdivididos da seguinte forma (OPM, 2004):

* Sistema Legal de Remuneração

- General Schedule: consiste em 15 notas (ou graus), cada uma geralmente definida por lei, em termos de grau de dificuldade do trabalho, responsabilidade e qualificações requeridas para o desempenho da função. Para cada nota, o salário pode variar em 10 níveis. Os funcionários vão avançando nessas notas de acordo com a qualidade do seu desempenho;

- Planos de remuneração Foreign Service foram estabelecidos pelo Foreign Service Act em 1980;

- Veterans Health Administration: provêem planos e remuneração únicos para seus físicos, dentistas, podólogos e oftalmologistas.

- Outros Sistemas Principais de Remuneração

- Wage System: engloba os funcionários do Sistema Federal de Pagamento (Federal Wage System), que cobre ocupações que requerem maior habilidade operacional;

- Executive Schedule: cargos do topo da esfera executiva;

- Administratively Determined Pay Systems: alguns chefes de agências são autorizados a determinar salários para toda a agência ou para grupos de posições particulares sem a necessidade do consentimento do General Schedule;

- Senior Executive Service (SES): cobre a maioria dos cargos de supervisão, gerência e política na esfera executiva que é classificada com nota acima de 15 no General Schedule. Há normalmente 6 níveis de salários que são determinados tanto pelo Presidente quanto pelo General Schedule. 
O órgão responsável pelo sistema de remuneração americano é o FEPCA - Federal Employee Pay Comparability Act, de 1990, que traça as orientações para o estabelecimento de um pagamento que seja comparável tanto para empregos federais quanto para empregos não federais. Estabelece planos especiais para algumas situações, como, por exemplo, funcionários de nível sênior, ou seja, servidores não supervisores e não gerentes classificados com nota acima de 15 no General Schedule (senior level - SL), juízes de lei administrativa (administrative law judges - AL), membros do Boards of Contract Appeals (CA), entre outros. O FEPCA também provê um ajuste anual no pagamento de funcionários do General Schedule que varia de acordo com a localidade, é o Locality Plan (CBO, 2002).

Uma pesquisa realizada pelo Escritório de Orçamento do Congresso (CBO Congression Budget Office) mostra que o pacote de benefícios oferecido pelo Governo Federal representa uma porção significativa da compensação dos funcionários. Em sua amostra, cerca de $26 \%$ a $50 \%$ do valor total refere-se ao pacote de benefícios (aposentadoria, seguro saúde, seguro de vida etc.) oferecido (CBO MEMORANDUM, 1998).

\subsection{Aposentadoria}

A aposentadoria nos Estados Unidos é de responsabilidade do Sistema de Aposentadoria do Serviço Civil (CSRS - Civil Service Retirement System). Juntamente com o Sistema de Aposentadoria dos Funcionários Federais (Federal Employees Retirement System), esse órgão cobre cerca de 2.7 milhões de funcionários, incluindo os funcionários do Correio (U.S. Postal Service). O CSRS foi estabelecido pelo Civil Service Retirement Act em 1920 e precedeu o Social Security (Seguridade Social) (CBO MEMORANDUM, 1998). 
Segundo dados do CBO (2002), as condições para o pedido de aposentadoria com relação a idade e tempo de serviço são as seguintes (há uma variação para cargos de periculosidade, como bombeiro, por exemplo):

* Com 55 anos e 30 anos de serviço;

Com 60 anos e 20 anos de serviço;

Com 62 anos e 5 anos de serviço.

A pensão que os servidores recebem é uma porcentagem do salário médio dos três anos com maiores ganhos como funcionário federal. Por meio de uma fórmula determinada por lei, determina-se a porcentagem que será paga (CBO MEMORANDUM, 1998).

Rodrigues (1995) dá um exemplo de como seria a regra para calcular a aposentadoria para um servidor do Executivo:

* $1 \frac{1}{2} \%$ da média salarial para 5 anos de serviço mais;

* $13 / 4 \%$ da média salarial para serviço acima de 5 anos e abaixo de 10 anos, mais;

* 2\% da média salarial para serviço acima de 10 anos.

Dessa forma, o servidor que se aposentasse com 35 anos de serviço, teria direito a um montante equivalente a $66,25 \%$ de seu salário anual.

Há, como aqui no Brasil, benefícios para o servidor que atinge a idade da aposentadoria compulsória, por tempo de serviço (de acordo com a idade), precocemente e por razões de saúde. 


\subsection{Estabilidade e Demissões}

Segundo Rodrigues (1995), não há na legislação americana um dispositivo de estabilidade como aqui no Brasil. Existe o direito de manutenção no emprego, mas que é muito flexível, sendo que o Governo pode dispensar um funcionário tanto por questões disciplinares ou não (como, por exemplo, corte de orçamento). Um funcionário é considerado efetivo (esta palavra não existe na lei americana) quando cumpre o período probatório de um ano de forma satisfatória. Se ele passar nas provas do concurso e for constatado durante o estágio que ele não é capacitado para aquele cargo, ele pode ser imediatamente exonerado. O servidor será efetivado ou não mediante avaliação realizada e justificada pelo seu superior imediato.

Com relação à demissão, não há garantia de que ela não vá acontecer, mesmo após a efetivação do servidor, principalmente se o seu desempenho for avaliado como fraco comparado aos padrões do sistema. Nestes casos, o Governo possui apoio da lei para demitir os indivíduos considerados como não adequados para promover a eficiência no serviço (RODRIGUES, 1995).

Apesar de não haver garantias de que o servidor não será demitido, isso raramente acontece (WILSON, 1986 apud RODRIGUES, 1995) ${ }^{16}$. Quando ocorre, o servidor demitido tem direito a seguro desemprego, além de indenização assegurada por lei. Seja qual for o motivo da dispensa do funcionário, esta somente acontece baseada em avaliações de desempenho, que é o principal elemento para assegurar a imparcialidade e a justiça.

\footnotetext{
${ }^{16}$ WILSON, J. American Government, institutions \& polities. Lexington, MA: D.C. Heath and Co., pp.367-8, 1986.
} 


\subsection{Direitos e deveres}

O documento "Padrão de Conduta Ética para Servidores da Divisão Executiva dos Estados Unidos" teve sua regulamentação final realizada pelo U.S Office of Government Ethics, revisada em outubro de 2002, e apresenta como deve ser a conduta do servidor público americano. Os próximos itens trazem alguns desses padrões (U.S. Office of Government Ethics, 2002):

O serviço público é de confiança pública: cada servidor tem a responsabilidade com o Governo dos Estados Unidos e com seus cidadãos de ser leal à Constituição, às leis e aos princípios éticos acima de ganhos privados. Para assegurar que cada cidadão possa ter confiança total na integridade do Governo Federal, cada servidor deve respeitar e aderir aos princípios de conduta ética apresentadas, assim como os padrões complementares contidos nas regulamentações de cada agência.

Princípios gerais: os princípios apresentados a seguir se aplicam a cada servidor. Quando uma situação não estiver prevista tal como apresentada nesta parte, os servidores devem aplicar os princípios apresentados nesta seção de acordo com o que for considerada uma conduta apropriada.

- O serviço público é de confiança pública, requerendo dos servidores lealdade à Constituição, às leis e aos princípios de ética acima de ganhos privados.

- Os servidores não devem manter interesses financeiros que entrem em conflito com um desempenho consciente de seu dever.

- Os servidores não devem engajar-se em transações financeiras utilizando-se de informações não públicas do Governo ou permitir o uso impróprio de tais informações para qualquer tipo de interesse privado. 
- O servidor não deve, exceto com permissão especial, solicitar ou aceitar qualquer presente ou outro item com valor monetário de qualquer pessoa ou entidade que esteja procurando por: ação oficial do servidor, fazer negócios com ou conduzir atividades reguladas pela agência do servidor.

- Os servidores devem ter esforço honesto no desempenho de seus deveres.

- Os servidores não devem fazer nenhum compromisso ou promessa intencional e não autorizada, de qualquer tipo, que possa colocar o governo em uma situação delicada.

- Os servidores não devem utilizar o escritório público para ganhos privados.

- Servidores devem agir imparcialmente e não devem dar tratamento preferencial para nenhuma organização privada ou qualquer indivíduo.

- Servidores devem proteger e conservar a propriedade Federal e não devem utilizála para outras atividades que não as autorizadas.

- Os servidores não devem se engajar em empregos ou atividades externas, incluindo a procura ou negociação por algum desses, que possa gerar conflito com as responsabilidades e deveres oficiais do Governo.

- Os servidores devem denunciar às autoridades responsáveis qualquer tipo de desperdício, fraude, abuso ou corrupção.

- Os servidores devem satisfazer de boa-fé suas obrigações como cidadãos, incluindo todas as obrigações financeiras, especialmente as impostas por lei (tais como os impostos Federal, Estadual ou local).

- Os servidores devem aderir a todas as regulamentações que provêem oportunidade igual para todos os americanos independentemente de sua raça, cor, religião, sexo, idade ou incapacidade física. 
- Os servidores devem tentar evitar quaisquer ações que possam aparentar um comportamento que viole a lei ou os padrões éticos apresentados nesta parte.

Estatutos relacionados: além dos padrões de conduta ética apresentados nesta parte, há alguns outros estatutos que proíbem determinadas condutas. Todos os servidores são avisados de que pode haver mais estatutos e regulamentações aplicáveis a eles de forma geral ou de acordo com suas agências.

* Direito de greve: os funcionários passaram a ter o direito de se organizarem livremente a partir da reforma de 1978, o que não implica que o direito à greve seja algo reconhecido pelo Governo Federal. Há uma lei federal, a P.L. 478, de $1^{\circ}$ de julho de 1946, que denota qualquer ato de greve no funcionalismo como algo ilegal. Apesar disso, há um órgão, o FLRA - Federal Labor Relations Authority que é responsável pelas negociações em situações de impasses trabalhistas (RODRIGUES, 1995).

\subsection{Considerações sobre os serviços públicos brasileiro e americano}

Neste item fazem-se necessárias algumas considerações sobre as duas realidades, a brasileira e a americana, no que tange ao funcionamento e regulamentação de seu funcionalismo público a fim de destacar as possíveis diferenças e semelhanças entre as duas.

Na década de 70, quando surgiu a administração pública gerencial, a intenção foi fazer por meio desta, com que a máquina burocrática do governo se tornasse mais eficiente, combatendo a corrupção facilitada pela burocracia existente. 
No início da década de 80 houve uma tendência em todo o mundo em prol de uma Reforma do Estado, a fim de modernizar a administração pública. Esse movimento avançou com uma rapidez impressionante e em nenhum outro momento houve um empreendimento dessa natureza. O novo paradigma da administração pública, ou seja, a substituição do modelo burocrático por um modelo gerencial foi a mola propulsora dessa tendência. Esse modelo gerencial baseia-se em conceitos advindos da administração privada, tais como downsizing, administração por objetivos, empowerment, qualidade total, serviços públicos voltados para o consumidor, entre outros (PEREIRA, 2004).

Juntamente com outros países, a Reforma do Estado dos EUA se limitou em fazer apenas ajustes, com algumas medidas, tais como: comercialização de órgãos públicos, descentralização no governo central, uso de mecanismos típicos de mercado etc. Segundo Pereira (2004), percebeu-se, logo após a implantação dessas medidas, que somente isso não seria suficiente para uma administração gerencial, que demanda aspectos mais complexos, tais como estratégias, processos, recursos humanos, estruturas organizacionais, poderes e políticas etc. Os EUA, por sua vez, adotavam a filosofia de deixar o administrador administrar, acreditando na melhoria contínua baseada na gestão da qualidade total.

Já no Brasil, foi criado o MARE - Ministério da Administração Federal e Reforma do Estado, a fim de que o governo federal pudesse aumentar sua governança por meio de uma administração profissional e moderna. Apesar do esforço de modernização, a Carta Magna continha alguns aspectos que acabaram por desencadear um retrocesso no processo de consolidação do modelo gerencial (PEREIRA, 2004). O retorno no regime único estatutário e a aposentadoria com proventos integrais são exemplos desses aspectos. Com a abertura comercial do governo Collor, o governo teve que mudar a sua abordagem econômica, alavancando novamente a administração pública gerencial. 
Pereira (2004) coloca ainda que, de maneira geral, a reforma gerencial efetivou-se, e as instituições necessárias para sua implantação foram aprovadas no Congresso Nacional. A gestão dessa nova administração seria, então, o principal desafio, sendo que a reforma, nesse sentido, ainda dá seus primeiros passos. Com o segundo governo Fernando Henrique Cardoso o processo teve sua continuidade, com a busca pelo fortalecimento das funções e de regulação e de coordenação do Estado, principalmente no nível federal, e a

descentralização vertical para os níveis estadual e municipal, das funções executivas da prestação dos serviços sociais e de infra-estrutura. Assim, pretendeu-se reforçar a governança, com a superação das dificuldades encontradas para se implementar as políticas públicas, devido à rigidez e ineficiência da máquina administrativa (PEREIRA, 2004, p.10).

Segundo Rodrigues (1995), as semelhanças do Projeto de Reforma Administrativa enviada pelo Governo Federal brasileiro ao Congresso Nacional com aspectos da legislação norte-americana são inegáveis. Alguns exemplos disso são a flexibilização da estabilidade e da forma de ingresso no serviço público por meio de concurso. $\mathrm{O}$ autor cita ainda que esse modelo é um avanço para a administração pública, levando ao sucesso administrativo, mas coloca a seguinte questão: "Será que o Brasil estaria preparado para afrouxar seu controle nos processos e transpor para sua administração pública esse modelo?”. A cultura brasileira reflete uma realidade dura com relação à corrupção dos políticos, uma vez que burlar a legislação ainda é muito comum, apesar da tentativa de controle de alguns: 
Corrupção, tráfico de influência e o uso da máquina administrativa com fins eleitorais sobrevivem no país às vésperas do século XXI. Se, com todos os dispositivos que permitem um controle dos processos, verificam-se abusos, como ficaria a administração pública no país se esses controles sobre os processos fossem relaxados em favor de uma ênfase nos 'resultados'? A experiência norte-americana com reformas administrativas certamente pode nos fornecer subsídios, mas jamais nos dará todas as respostas para tais indagações (RODRIGUES, 1995, p. 124).

A questão cultural é fator de influência relevante no contexto político brasileiro, uma vez que para que haja uma real mudança e efetivação de todos os processos de reforma já iniciados, em andamento e também (e por que não) os que ainda estão por vir,é necessário uma mudança de paradigma não somente nos processos políticos e gerenciais, mas, principalmente, nos modelos mentais dos indivíduos que estão envolvidos nas formulações e práticas das políticas do nosso país. 


\section{CAPÍTULO 6 - METODOLOGIA DE PESQUISA}

Neste capítulo será exposta a metodologia utilizada nesta pesquisa, em que são apresentados o tipo de estudo realizado; o local onde foi coletada a amostra; a população e amostra da pesquisa; os instrumentos de mensuração utilizados; o procedimento de coleta de dados; o tratamento dos dados quanto à normalidade e missing values; e a análise de dados, com detalhamento dos dois tipos de validação utilizados (de constructo e de critério) e suas respectivas ferramentas estatísticas: análise fatorial exploratória, análise fatorial confirmatória, modelagem de equações estruturais e correlação de Spearman.

\subsection{DEFINIÇÃO DE TERMOS E VARIÁVEIS}

O escopo do constructo PSM - Public Service Motivation estudado nesta pesquisa é a motivação. O processo de validação de constructo foi desenvolvido para validar o instrumento de medida desse constructo. A verificação da existência de uma relação entre o PSM e o constructo do Comprometimento Organizacional foi realizada como etapa inicial da validação de constructo. Assim, os dois conceitos principais da pesquisa são definidos a seguir. 


\subsubsection{Motivação no Serviço Público}

Perry e Wise (1990) definiram PSM como "a predisposição de um indivíduo para responder a motivos baseados primeiramente ou unicamente em instituições ou organizações públicas". O conceito de motivo foi utilizado por Perry (1996, p. 6) como "deficiências psicológicas ou necessidades que um individuo possui e que ele sente uma compulsão por eliminar”.

\subsubsection{Comprometimento}

Para Bastos (1995 apud PEREIRA; OLIVEIRA, 2000, p. 4) ${ }^{17}$, o comprometimento é uma "adesão, um forte envolvimento do indivíduo com variados aspectos do ambiente de trabalho".

${ }^{17}$ BASTOS, A .V.B. Comprometimento organizacional: de o estado da arte a uma possível agenda pesquisa. In: Cadernos de Psicologia, n.01, p. 44-63. São Paulo: 1995. 


\subsection{TIPO DE ESTUDO}

Para uma melhor compreensão do tipo de estudo, torna-se necessário apresentar a diferenciação dos termos método e técnica. Para Cervo e Bervian (2003, p. 25)

por método entende-se o dispositivo ordenado, o procedimento sistemático, em plano geral. A técnica, por sua vez, é a aplicação do plano metodológico e a forma especial de o executar. A técnica está subordinada ao método, sendo sua auxiliar imprescindível.

A pesquisa quantitativa, segundo Richardson (1999), é caracterizada pela quantificação tanto na coleta quanto no tratamento dos dados e representa, em princípio, a intenção de dar a melhor precisão possível dos resultados. É comumente aplicada a estudos descritivos. A técnica de pesquisa descritiva se desenvolve principalmente nas ciências humanas e sociais e busca conhecer as diferentes situações e relações existentes na vida política, social e demais aspectos do comportamento do indivíduo isolado ou em grupo (CERVO; BERVIAN, 2002). Ainda segundo esses autores, a pesquisa descritiva pode assumir várias formas, e uma delas é a pesquisa motivacional.

Sendo assim, o presente estudo pode ser caracterizado como um estudo quantitativo e descritivo, uma vez que utilizará o método survey para a coleta dos dados e identificará e descreverá um fenômeno. 


\subsection{POPULAÇÃO}

Os dados foram coletados na cidade de Ribeirão Preto, estado de São Paulo, nas Secretarias Municipais da Fazenda, da Saúde e de Administração, sendo que o total de funcionários de cada uma é o seguinte (informação pessoal) ${ }^{18}$ :

Secretaria Municipal da Fazenda de Ribeirão Preto: 262 servidores;

Secretaria Municipal da Saúde de Ribeirão Preto: 3.414 funcionários, sendo que nas duas unidades pesquisadas, 300 são servidores da sede da secretaria e 207 são servidores da unidade de Controle de Vetores e Zoonozes.

Secretaria Municipal de Administração de Ribeirão Preto: 80 servidores.

\subsection{AMOSTRA}

Segundo Vergara (2004), existem dois tipos de amostra: não-probabilística (por acessibilidade ou por tipicidade) e probabilística (baseada em procedimentos estatísticos). No presente estudo foi utilizada uma amostra não-probabilística por acessibilidade, ou seja, não foi utilizado nenhum método estatístico para a escolha da mesma, pelo seguinte motivo: a amostra foi composta de acordo com o número de questionários respondidos devolvidos. Houve grande dificuldade em conseguir um número satisfatório de respondentes, uma vez que foi distribuído um número significativo de questionários (540), mas o retorno foi muito

\footnotetext{
${ }^{18}$ Informação obtida em visitas realizadas aos locais.
} 
pequeno. A pesquisa objetivou atingir um índice de resposta de pelo menos $70 \%$, o que não foi possível, atingindo um índice de somente 36\%, ou 196 questionários. Seis questionários foram excluídos, por dois motivos:

1. Não foram totalmente respondidos, com até uma escala inteira sem resposta, o que invalida a inclusão dos mesmos. Estes questionários foram originados das Secretarias Municipais de Administração (1) e da Saúde (3);

2. Os respondentes não possuíam um vínculo efetivo e/ou duradouro com a instituição, estando no cargo de estagiários, o que poderia ser um empecilho para a análise da escala de comprometimento, uma vez que suas respostas destoam das demais, fazendo com que essa variável não seja adequada como critério no processo de validação de critério. Estes questionários foram originados da Secretaria Municipal da Administração (2).

Assim, a amostra do presente estudo foi composta da seguinte forma (tabela 1):

Tabela 1 - Composição da amostra

\begin{tabular}{l|c}
\hline \multicolumn{1}{c|}{ Secretaria } & No. Funcionários respondentes \\
\hline Fazenda & 35 \\
\hline Saúde - Sede & 57 \\
\hline Saúde - Unidade de Controle de Vetores & 79 \\
\hline Administração & 25 \\
\hline Excluídos & 6 \\
\hline \multicolumn{2}{r}{ TOTAL } \\
\hline
\end{tabular}

Dos 190 respondentes, $52,1 \%$ são do sexo feminino e 47,9\% do sexo masculino; a idade média é de aproximadamente 41 anos variando de 15 a 59 anos; 56,3\% são casados e 25,8\% são solteiros; com relação à escolaridade, 44,2\% concluíram o segundo grau, seguido de $24,7 \%$ que concluíram o ensino superior; somente $8,9 \%$ fizeram pós-graduação; quanto a 
renda familiar mensal bruta, 44,2\% ganham entre $R \$ 701,00$ e $R \$ 1.700,00$, seguidos por $21,1 \%$ que ganham entre $\mathrm{R} \$ 1.701,00$ e $\mathrm{R} \$ 2.700$ e $15,8 \%$ que ganham acima de $\mathrm{R} \$ 3.701,00$; o tempo médio de serviço é de 12,48 anos, sendo o mínimo de 1 e o Maximo de 35 anos; quanto ao vinculo do servidor, $71,1 \%$ são efetivos e $27,9 \%$ são temporários ou comissionados (sendo que os estagiários foram excluídos dessa opção).

\subsection{INSTRUMENTO DE MENSURAÇÃO}

Como a escala estudada é originada de um país estrangeiro, foi realizado um procedimento de tradução do instrumento, da seguinte maneira: segundo Guillemin, Bombardier e Beaton (1993), a adaptação transcultural de um instrumento é composta por dois aspectos: a tradução deste instrumento e sua adaptação, propriamente dita. Sendo assim, é necessária a tradução literal das palavras e sentenças, do idioma nativo para o desejado, de

um contexto cultural para outro. A back-translation é o procedimento de re-tradução do instrumento, quer dizer, o instrumento é traduzido do idioma adaptado para o idioma nativo, e então se faz uma comparação das duas versões. Devem ser realizadas tantas back-translations quantas traduções (LINO, 1999). Assim, como recomendado pelos autores acima citados, foi realizado o procedimento de tradução e adaptação da escala para a língua portuguesa.

O instrumento de medida da escala de PSM foi desenvolvido em 1996 por Perry, a partir do constructo de Public Service Motivation. Por ser um constructo novo, não havia nenhuma escala de medida para ele. O questionário foi validado nos EUA utilizando a técnica de análise fatorial confirmatória e tem sido utilizado em pesquisas, principalmente na área de administração pública. 
Originalmente Perry (1996), ao iniciar o desenvolvimento do questionário, preocupouse com a validação do constructo e por esse motivo, a escala foi criada a partir das dimensões identificadas na revisão da literatura. Foi utilizada uma escala de Likert de cinco pontos (variando de concordo totalmente a discordo totalmente) para cada uma das seis dimensões encontradas inicialmente. Os termos utilizados para cada item basearam-se inicialmente, nos termos utilizados em outros estudos sobre motivação aplicada ao serviço público. Aproximadamente 35 itens foram criados por meio da revisão da literatura e de uma discussão num grupo de foco com alunos do MPA - Master in Public Administration.

A partir daí, uma revisão foi realizada por Perry (1996) com os estudantes, que, após responderem ao questionário, deram um feedback sobre os itens que mais capturaram os fatores motivacionais que levavam o indivíduo para a carreira no setor público. Uma outra versão foi formulada a partir da aplicação da primeira e então foram criados itens por meio de uma discussão num grupo de foco realizado com alunos de MPA - Master in Public Administration e MBA - Master in Business Administration. A nova escala foi testada novamente comparando estudantes de outras turmas dos mesmos cursos (MPA e MBA). Correlações entre os itens e totais foram computadas, e dessa última versão revisada, resultaram 40 itens e 6 dimensões. A medida de consistência interna Alpha de Cronbach foi computada para as seis subescalas (dimensões) e depois de outras revisões, Perry chegou à versão final, com quatro dimensões: atração por formulação de políticas públicas, comprometimento com o interesse público, compaixão e auto-sacrifício, totalizando 24 itens. As outras dimensões foram eliminadas pois o processo de formulação do modelo indicou que os respondentes não discriminaram significantemente os constructos de dever cívico, justiça social e comprometimento com o interesse público, as três dimensões associadas com os motivos baseados em normas. 
O quadro 5 traz o questionário traduzido, dividido de maneira que cada dimensão forma uma subescala com as afirmativas correspondentes a ela. É importante destacar que o questionário não foi aplicado dessa forma, e sim, na ordem crescente das afirmativas. Ele foi apresentado desta maneira no presente estudo para melhor visualização da divisão dos itens pelas dimensões.

\section{Quadro 5. Questionário traduzido do PSM, dividido em relação às subescalas}

Atração pela formulação de políticas públicas (5 itens)
PSM 11 - Política é uma boa palavra.
PSM 27 - A troca (o ato de dar e receber) na formulação de políticas públicas me atrai.
PSM 31 - Eu me importo muito com os políticos.
Comprometimento com o Interesse Público (7 itens)
PSM 16 - É fácil para mim me envolver intensivamente nos acontecimentos da minha comunidade.
PSM 23 - Eu contribuo de maneira não egoísta (generosamente) com minha comunidade.
PSM 30 - Um serviço público significativo é muito importante para mim.
PSM 34 - Eu preferiria ver funcionários públicos fazerem o que é melhor para toda a comunidade,
mesmo que se isso afetasse meus interesses pessoais.
PSM 39 - Eu considero o serviço público meu dever civil.
Compaixão (8 itens)
PSM 2 - Freqüentemente eu sou motivado pela situação difícil dos desprivilegiados.
PSM 3 - A maioria dos programas sociais é importante demais para se viver sem.
PSM 13 - Eu freqüentemente sou lembrado por acontecimentos do cotidiano sobre o quanto nós
passo para ajudarem a si mesmas.
PSM 40 - Há vários programas públicos que eu apoio sinceramente.
PSM 8 - É difícil para mim, para conter meus sentimentos quando vejo alguém na miséria.
Po - Eu freqüentemente penso no bem-estar das pessoas que eu não conheço pessoalmente.


Auto-sacrifício (8 itens)

PSM 1 - Fazer a diferença na sociedade representa mais para mim do que realizações pessoais.

PSM 5 - Eu acredito em colocar o dever antes de si mesmo.

PSM 6 - Realizar boas ações é definitivamente mais importante do que se dar bem financeiramente.

PSM 9 - Muito do que eu faço é por uma causa maior do que eu mesmo.

PSM 12 - Servir aos cidadãos me faria sentir bem, mesmo que eu não fosse pago por isso.

PSM 17 - Eu acredito que as pessoas devem devolver à sociedade mais do que recebem.

PSM 19 - Eu sou uma daquelas raras pessoas que arriscariam perdas pessoais a fim de ajudar alguém.

PSM 26 - Eu estou preparado para fazer sacrifícios enormes pelo bem da sociedade.

A segunda parte do questionário contém a escala de comprometimento validada por Bastos (1995), como demonstrado no quadro 6, que traz o questionário dividido de forma que cada dimensão forma uma subescala com as afirmativas correspondentes a ela. É importante destacar que o questionário não será aplicado dessa forma, e sim, com as afirmativas distribuídas de forma aleatória. Ele foi apresentado desta maneira no presente estudo para melhor visualização da divisão dos itens pelas diferentes bases. 


\title{
Quadro 6. Questionário da escala de comprometimento de Meyer e Allen adaptada por Bastos (1995)
}

\author{
Escala de comprometimento organizacional de base afetiva (6 itens) \\ Eu seria muito feliz em dedicar o resto da minha carreira nesta organização. \\ Eu realmente sinto os problemas da organização como se fossem meus. \\ Eu não sinto um forte senso de integração com esta organização. \\ Eu não me sinto emocionalmente vinculado a esta organização. \\ Eu não me sinto como uma pessoa de casa nesta organização. \\ Esta organização tem um imenso significado pessoal para mim.
}

Escala de comprometimento organizacional de base instrumental (6 itens)

Na situação atual, ficar nesta organização é na realidade uma necessidade mais do que um desejo.

Mesmo que eu quisesse, seria muito difícil para mim deixar esta organização agora.

Se eu decidisse deixar esta organização agora, minha vida ficaria bastante desestruturada.

Eu acho que teria poucas alternativas se deixasse esta organização.

Se eu já não tivesse dado tanto de mim nesta organização, eu poderia pensar em trabalhar num outro lugar.

Uma das poucas conseqüências negativas de deixar esta organização seria a escassez de alternativas imediatas.

Escala de comprometimento organizacional de base normativa (6 itens)

Eu não sinto nenhuma obrigação de permanecer nesta organização.

Mesmo se fosse vantagem para mim, sinto que não seria certo deixar esta organização agora.

Eu me sentiria culpado se deixasse esta organização agora.

Esta organização merece minha lealdade.

Eu não deixaria esta organização agora porque tenho uma obrigação moral com as pessoas daqui.

Eu devo muito a esta organização. 
A terceira parte do questionário contém os seguintes dados demográficos: sexo, idade, estado civil, grau de escolaridade, renda mensal familiar, tempo de serviço e tipo de vínculo do servidor com o serviço público.

\subsection{COLETA DE DADOS}

A coleta dos dados da pesquisa foi realizada pela aplicação do questionário descrito no item anterior, composto por três etapas. Por meio de uma visita da pesquisadora aos locais da pesquisa, primeiramente os responsáveis pelas seções e posteriormente os respondentes de cada seção foram convidados e orientados a cooperar com a pesquisa. Essa orientação para o preenchimento consistiu em solicitar ao respondente a ler as instruções do questionário e marcar a alternativa que correspondesse à sua opinião, sendo que foi ressaltado o anonimato dos mesmos. Como o questionário é auto-aplicável, foram distribuídos aos servidores das secretarias pesquisadas e recolhidos posteriormente, em prazos determinados pelos responsáveis de cada seção.

\subsection{TRATAMENTO DOS DADOS}

Essa etapa da pesquisa é muito importante, apesar de muitas vezes negligenciada (Hair et al., 1998). Mesmo com a utilização de técnicas multivariadas, os dados da amostra devem ser ajustados às técnicas que serão utilizadas e ao objetivo que se pretende atingir. No caso 
desta pesquisa, os dados foram tratados a fim de satisfazerem alguns parâmetros para os dados amostrais exigidos para a utilização das técnicas de Análise Fatorial Exploratória, Análise Fatorial Confirmatória e Modelagem de Equações Estruturais. Os principais aspectos levados em consideração foram: a presença de missing values e a avaliação da normalidade dos dados.

\subsubsection{Missing Values}

A existência de missing values nas pesquisas é muito comum. Os motivos variam: pode acontecer porque um respondente deixa de responder a uma ou algumas questões, por problemas na tabulação dos dados etc. O ideal é evitar que o índice de missing values da amostra seja muito alto.

Hair et al. (1998) apresenta três abordagens para o tratamento desses valores: 1) listwise (retirada completa dos casos que possuem valores faltantes); 2) pairwise (retirada dos valores faltantes somente no momento em que ele aparece nos dados) e 3) model-based ou método de imputação (substituição pela média). O último modelo, apesar de controverso, segundo os mesmo autores, é muito utilizado. O método de imputação foi escolhido para esta pesquisa por não deletar os casos completamente, o que foi de extrema valia pela dificuldade de se conseguir uma amostra com um número de observações adequado para a análise. 


\subsubsection{Normalidade}

A fim de avaliar se a amostra é ou se aproxima de uma distribuição normal, foi realizado a análise de Kolmogorov-Smirnov (KS), que tem como finalidade comparar os escores da amostra com os escores de uma distribuição normal com a mesma média e desviopadrão (FIELD, 2005). O resultado não apresentou uma distribuição dos dados amostrais que se aproxima de uma distribuição normal, mesmo quando os dados foram padronizados a fim de verificar a existência de uma possível diferença.

\subsection{ANÁLISE DOS DADOS}

A análise dos dados foi realizada pelo processo de validação de constructo e de critério do instrumento de mensuração. Para o primeiro processo, foram utilizadas principalmente duas ferramentas estatísticas: a Análise Fatorial e a Modelagem de Equações Estruturais. Já para o segundo foi utilizada a correlação de Spearman. A seguir serão apresentadas considerações importantes sobre cada um dos processos de validação. 


\subsubsection{Validação do instrumento de mensuração}

Isaac e Michael (1971, p. 83) afirmam que a "informação de validade indica o grau em que determinado teste é capaz de atingir objetivos especificos". De acordo com Cooper e Schindler (2003), a validação pode ser externa ou interna. A primeira refere-se à capacidade dos resultados obtidos serem generalizados entre as pessoas, um determinado ambiente ou época; a segunda refere-se à capacidade do instrumento de medir o que realmente deve ser medido.

Neste estudo será utilizada a validação interna, que refere-se ao quanto o grau em que as diferenças medidas por um instrumento de mensuração refletem a realidade dos indivíduos testados (COOPER; SCHINDLER, 2003). Estes autores conceituam três tipos de validação: a de critério, de conteúdo e de constructo.

A construção (e a aferição) dos instrumentos psicológicos possui técnicas e teorias diferentes que a fundamentam. Pasquali (1999) utiliza as definições de validação por critérios, constructo e conteúdo da seguinte forma:

Testes referentes a critérios: caracterizados por sua capacidade de discriminar gruposcritério, adquirem sua validade por meio dessa capacidade de diferenciação clara entre esses grupos.

* Testes referentes a constructo: não partem de qualquer dado empírico, mas sim da teoria. Representam por meio dos itens, os traços latentes, ou seja, os constructos. Neste tipo de teste, o importante é a representação adequada do traço latente.

Testes referentes a conteúdo: especificam um conteúdo e não tipos de pessoa. A qualidade desse teste depende da representatividade da amostra de um conteúdo definido. 
Segundo Malhotra (2006), a validade de conteúdo também pode ser chamada de validade nominal, que avalia subjetivamente (mas de forma sistemática) a exatidão do conteúdo da uma escala. Na validade de critério, o autor a classifica em dois tipos: preditiva e concomitante. Esta última é denominada por Cooper e Schindler (2003) como concorrente.

Polit e Hungler (1995) citam também a validade aparente, que é a determinação da compreensão e clareza dos itens do instrumento, realizada por peritos e juízes (como na validade de conteúdo) que conheçam o objetivo e a importância da análise da clareza, da facilidade de leitura, da compreensão e da forma de apresentação do instrumento.

De acordo com Isaac e Michael (1971), o termo validade de face é utilizado para indicar se o instrumento aparenta medir o que realmente deseja. Os autores colocam que, apesar de não ser um conceito rigoroso, é importante que ele não seja ignorado, pois sua utilização em conjunto com os outros tipos de validade, reforçam a aceitação geral do instrumento.

Diferentes testes são utilizados para vários tipos de julgamento, e para cada um deles, um tipo diferente de investigação é requerido para estabelecer a validade. Podem ser identificados três principais objetivos de testes a fim de descrever, posteriormente, o uso dos três tipos de validação (ISAAC; MICHAEL, 1971):

* O usuário deseja determinar o desempenho de um indivíduo no presente num universo de possibilidades que a situação do teste demanda representar.

* O usuário deseja prever a posição futura de um indivíduo ou estimar a posição presente deste, em alguma variável, com uma importância particular diferente da do teste (Exemplo: um teste de aptidão acadêmica pode prever notas). 
* O usuário deseja inferir o grau pelo qual o indivíduo possui determinado traço hipotético ou qualidade (constructo) presumida que pode ser refletida pelo seu desempenho no teste.

Para determinar o quanto um teste é ajustável para cada um dos usos citados anteriormente, é necessário coletar as informações realmente necessárias para a validade, ou seja, o tipo de informação a ser coletada vai depender mais do objetivo do teste do que do tipo do teste. Os três aspectos de validade abaixo correspondem a cada um dos objetivos citados, respectivamente (Vários autores utilizam três principais conceitos de validade: de constructo, de conteúdo e de critério ou preditiva (tabela 2) (CARMINES; ZELLER, 1979, ISSAC; MICHAEL, 1971, SILVA; RIBEIRO FILHO, 2006, COOPER, SCHINDLER, 2003, PASQUALI, 1999, MALHOTRA, 2006, NUNNALLY, 1978, HAIR ET AL., 2005):

* Validade de conteúdo: depende da extensão em que uma medida empírica reflete um domínio específico de conteúdo; examina a extensão em que a especificação sobre a qual a escala foi planejada e construída e com isso reflete o propósito particular para a qual está sendo desenvolvida. Baseia-se no julgamento de especialistas que avaliam a relação entre partes da escala e o universo definido. Avaliam o grau no qual o pesquisador traduz adequadamente o constructo de interesse numa operação elaborada para mensurá-lo;

Validade relacionada a critério: também chamada de validade preditiva. Usada quando o propósito é usar um instrumento para estimar alguma forma importante de comportamento que é externo ao instrumento de medida em si, este último sendo referido como um critério. O indicador operacional do grau de correspondência entre o teste e o critério é usualmente estimado pelo tamanho de sua correlação; 
* Validade de constructo: é tecida nas ciências sociais, pois diz respeito a uma investigação onde não há um critério ou conteúdo universal aceito como inteiramente adequado para definir uma qualidade a ser mensurada. é considerada a mais difícil e complexa das validades. Diz respeito ao grau em que uma escala, ou um conjunto de subescalas, mede a teoria ou a hipótese de investigação.

A validade de constructo é relevante quando não há uma medida que possa ser considerada como padrão (ou critério) para o que é desejado medir ou quando o teste será utilizado em decisões tão diversas que nenhum padrão pode ser aplicado.

O objetivo do presente estudo vai ao encontro do segundo e do terceiro objetivos expostos por Isaac e Michael (1971) citados acima e, dessa forma, utilizará a validade de constructo no processo de validação da escala de Motivação no Serviço Público. O quadro 7 mostra o resumo dos principais tipos de validade. 
Quadro 7. Principais tipos de validade, objetivos, métodos e usos mais comuns

\begin{tabular}{|c|c|c|c|}
\hline TIPO DE VALIDADE & OBJETIVO & MÉTODO & $\begin{array}{l}\text { USO MAIS } \\
\text { COMUM }\end{array}$ \\
\hline Conteúdo & $\begin{array}{l}\text { Demonstra o grau em } \\
\text { que uma amostra de } \\
\text { itens, tarefas ou } \\
\text { questões de uma } \\
\text { escala é } \\
\text { representativa de um } \\
\text { universo definido ou } \\
\text { de um domínio de } \\
\text { conteúdo. }\end{array}$ & $\begin{array}{c}\text { Conclui se o } \\
\text { conteúdo do teste } \\
\text { contém uma } \\
\text { definição adequada } \\
\text { do que deve ser } \\
\text { medido }\end{array}$ & $\begin{array}{c}\text { Testes para atingir } \\
\text { objetivos }\end{array}$ \\
\hline Critério & $\begin{array}{c}\text { É demonstrada } \\
\text { comparando os } \\
\text { escores do teste com } \\
\text { um ou mais escores } \\
\text { de variáveis externas } \\
\text { consideradas no } \\
\text { estudo para dar uma } \\
\text { medida direta da } \\
\text { característica ou } \\
\text { comportamento em } \\
\text { questão }\end{array}$ & $\begin{array}{c}\text { Dá o teste e o } \\
\text { compara com a } \\
\text { variável de critério } \\
\text { (ou padrão). }\end{array}$ & $\begin{array}{l}\text { Testes utilizados } \\
\text { para procedimentos } \\
\text { mais complexos ou } \\
\text { para selecionar e } \\
\text { classificar pessoas }\end{array}$ \\
\hline Construto & $\begin{array}{l}\text { Habilidade de uma } \\
\text { escala para confirmar } \\
\text { as hipóteses } \\
\text { esperadas; é um } \\
\text { julgamento sobre a } \\
\text { adequação das } \\
\text { inferências delineadas } \\
\text { dos escores da escala, } \\
\text { considerando o } \\
\text { posicionamento } \\
\text { individual numa } \\
\text { variável que mede um } \\
\text { dado constructo. }\end{array}$ & $\begin{array}{l}\text { Baseado na teoria que } \\
\text { "compõe" o teste, } \\
\text { formular hipóteses } \\
\text { relacionadas com o } \\
\text { comportamento de } \\
\text { pessoas com altos ou } \\
\text { baixos scores. A } \\
\text { partir daí, testar as } \\
\text { hipóteses. }\end{array}$ & $\begin{array}{c}\text { Testes utilizados } \\
\text { para descrição ou } \\
\text { pesquisa científica. }\end{array}$ \\
\hline
\end{tabular}

Fonte: Adaptado de Isaac e Michael, 1971, p. 82 e Silva e Ribeiro Filho, 2006, p.99. 


\subsubsection{Pré-teste}

Há algumas formas de utilização de um pré-teste a fim de refinar um instrumento. Cooper e Schindler (2003) apresentam duas formas:

* Pré-teste do pesquisador: informal, realizado nos primeiros estágios estrutura melhor os testes com o passar do tempo. Pode ser realizado por outros pesquisadores e suas sugestões podem trazer melhorias ao ajuste do instrumento.

* Pré-teste do respondente: exige a aplicação em uma amostra de respondentes ou respondentes substitutos (pessoas com características e formação semelhantes ao público-alvo). A distribuição também deve ser realizada da mesma forma que o instrumento verdadeiro.

Duas abordagens também podem ser assumidas (COOPER; SCHINDLER, 2003):

* Pré-testes colaborativos: o respondente é informado sobre o objetivo da pesquisa, e sob essas condições, a comprovação detalhada das partes de cada um dos itens é mais apropriada.

* Pré-testes não-colaborativos: quando o pesquisador ao informar o respondente, pode perder sugestões importantes, pela falta de comprometimento do respondente.

No presente estudo, será realizado um pré-teste do respondente, com uma amostra de respondentes assumindo a abordagem colaborativa. A realização do pré-teste será relevante, também, para a validação de face ou aparente, uma vez que o respondente exporá seu entendimento com relação à clareza da redação e do significado dos itens. 


\subsubsection{Validade de constructo}

Para Cronbach (1996), constructo vem de "construe", uma maneira de construir, organizar o que é observado. Na psicologia o termo construto é usado para referir a algo que não é observável, mas que é literalmente construído pelo investigador para resumir ou quantificar as regularidades ou relacionamentos que são observados no comportamento e pode ser usado com o sentido de significado e correspondência (THORNDIKE; HAGEN, 1977). Hair et al. (2005) afirmam que é necessário entender a fundamentação subjacente às medidas que o pesquisador obtém; a teoria é utilizada para explicar por que funciona e como os resultados de sua aplicação podem ser interpretados. Isaac e Michael (1971), complementam essa idéia ao dizer que o constructo é utilizado quando a variável é mais abstrata do que concreta, e é estudada geralmente quando o pesquisador deseja aumentar seu entendimento sobre qualidades psicológicas medidas pelo teste. Os autores falam ainda que o constructo pode representar uma hipótese de que a variedade de comportamentos serão correlacionados com um outro em estudos de diferenças individuais e/ou serão similarmente afetados por tratamentos experimentais.

Silva e Ribeiro Filho (2006) propõem um modelo de processo de determinação da validade de constructo de uma escala envolvendo a conexão do domínio teórico e do domínio das medidas. A figura 5 demonstra esse modelo: 


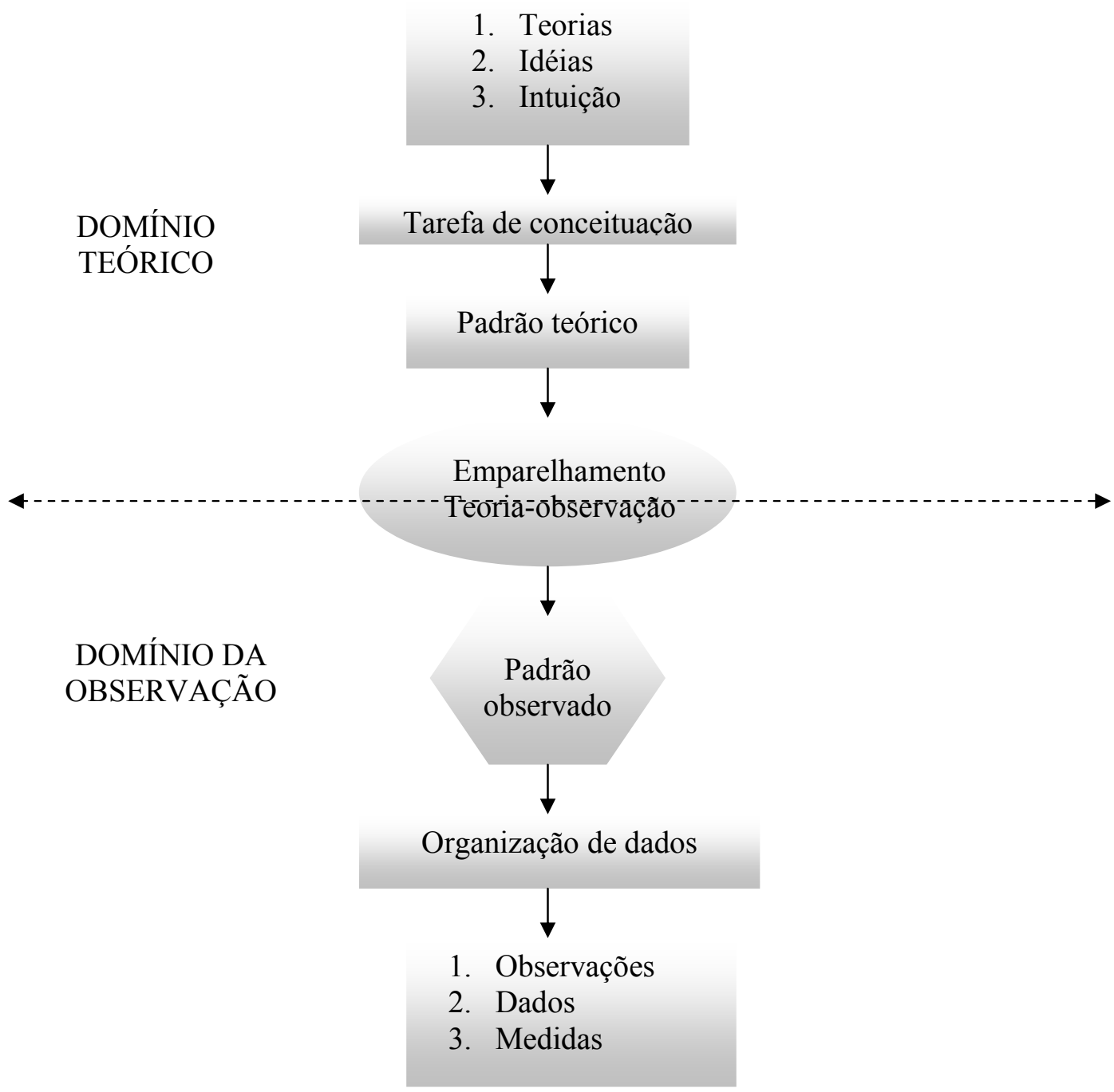

Figura 5. Processo de determinação da validade de constructo de uma escala envolvendo a conexão do domínio teórico e do domínio das medidas

Fonte: Silva e Ribeiro Filho, 2006, p.100.

Nessa proposta, o domínio teórico expõe a teoria do constructo estudado, enquanto que no domínio da observação são definidas as etapas e técnicas de aplicação do instrumento, assim como a coleta da informação a fim de se fazer o emparelhamento da teoria com os dados observados e a análise. 
Pasquali (1999) também possui um modelo para a elaboração de uma escala psicológica que se baseia no que ele define como três grandes polos: (1) polo teórico: expõe a teoria do traço latente (constructo), com a explicação dos tipos e categorias de comportamentos que representam de forma adequada esse traço; (2) polo empírico: define as etapas e técnicas da aplicação do instrumento piloto, assim como da coleta válida da informação a fim de se realizar uma avaliação da qualidade psicométrica do instrumento; (3) polo analítico: estabelece os procedimentos das análises estatísticas que devem ser realizadas a fim de garantir a validade do instrumento.

Os procedimentos teóricos são elaborados de acordo com cada instrumento, a depender da literatura existente sobre o constructo que o instrumento deseja medir. Esse procedimento é muito importante, pois é o que possibilita uma construção adequada e coerente dos itens. Há pesquisadores que coletam amostras de itens aleatórias, o que se chama de validade de face, ou seja, o que parece embasar o traço latente para o qual se pretende construir um instrumento de medida. Nos procedimentos experimentais, a definição da amostra é muito importante, pois ela sairá da definição clara e objetiva da população-alvo, ou seja, a caracterização sócio-demográfica dessa população. O tamanho da amostra também deve ser escolhido de acordo com os critérios exigidos pela ferramenta estatística que será utilizada posteriormente (PASQUALI, 1999).

Silva e Ribeiro Filho (2006, p. 108) apresentam quatro fases para o processo de validação de constructo:

1. Fase teórica: análise lógica da teoria pela qual os contructos são derivados e as relações entre vários destes constructos. 
2. Fase da formulação de hipóteses: implementação de certas hipóteses a respeito do comportamento das pessoas que possuem níveis alto ou baixo no constructo derivado da teoria.

3. Fase empírica: os dados são obtidos para testar a relação entre as medidas de dois (ou mais) constructos.

4. Fase de inferências: o pesquisador interpreta os dados coletados e chega a uma conclusão, ou seja, se a teoria explica (ou não) ou é corroborada (ou não) pelos dados obtidos.

Os dois modelos apresentados representam muito bem o tipo de procedimento adequado a ser realizado quando da utilização da validade de constructo e são bastante semelhantes, uma vez que delineiam claramente os domínios ou polos da teoria e da observação. Da mesma maneira, as fases do processo apresentadas por Silva e Ribeiro Filho (2006) são claras e precisas a respeito das etapas a serem seguidas.

O presente estudo desenvolve-se na fase de emparelhamento da teoria já existente sobre o constructo do PSM (Public Service Motivation) e a observação dos dados que serão coletados no Brasil, uma vez que a escala já foi construída e validada nos EUA e o objetivo desta pesquisa é validá-la para a realidade brasileira. Assim, o presente estudo cumprirá as fases 2, 3 e 4 propostos por Silva e Ribeiro Filho (2006). A figura 6 mostra como será desenvolvido o processo de validação de constructo do instrumento de Motivação no Serviço Público do presente estudo. 


\section{Domínio teórico $\longrightarrow$ Fase 1: teórica $\longrightarrow$ Teoria do PSM}

Fase 2:

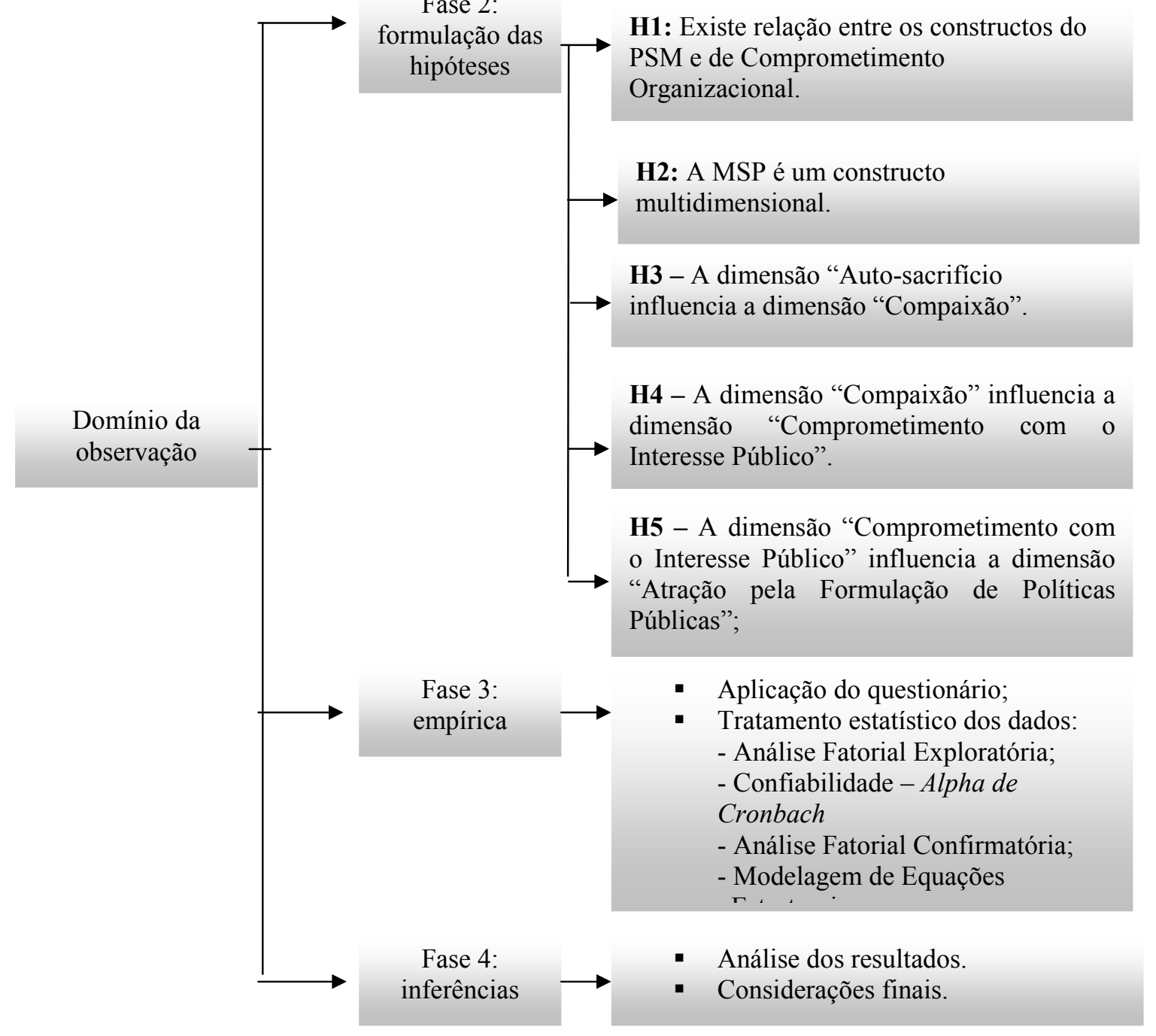

\section{Figura 6. Processo de validação de constructo do instrumento de MSP - Motivação no Serviço Público}

Abaixo estão descritas mais detalhadamente o desenvolvimento de cada uma dessas fases:

Fase 1: teoria do PSM. Esta se encontra descrita no referencial teórico deste trabalho (capítulo 2). 


\section{Fase 2: formulação de hipóteses}

Levando com consideração a afirmativa de Anderson, Sweeney e Willliams (2002, p.321) de que "a hipótese alternativa é o que o teste está tentando estabelecer" e baseado na teoria do PSM, foram formuladas 5 hipóteses de pesquisa alternativas, que podem ser observadas na tabela 2, com suas respectivas técnicas estatísticas:

\section{Tabela 2 - Hipóteses de pesquisa e técnica estatística utilizada}

\begin{tabular}{l|l}
\hline \multicolumn{1}{c|}{ Hipóteses Alternativas } & \multicolumn{1}{c}{ Técnica Utilizada } \\
\hline $\begin{array}{l}\text { H1: Existe relação entre os constructos do PSM e de } \\
\text { Comprometimento Organizacional. }\end{array}$ & Correlação de Spearman. \\
\hline H2: O PSM é um constructo multidimensional & $\begin{array}{l}\text { Análise Fatorial Exploratória } \\
\text { Análise de Consistência Interna } \\
\text { Análise Fatorial Confirmatória }\end{array}$ \\
\hline $\begin{array}{l}\text { H3 - A dimensão “Auto-sacrifício" influencia na dimensão } \\
\text { "Compaixão". }\end{array}$ & Modelagem de Equações Estruturais \\
\hline $\begin{array}{l}\text { H4 - A dimensão "Compaixão" influencia dimensão } \\
\text { "Comprometimento com o Interesse Público". }\end{array}$ & Modelagem de Equações Estruturais \\
\hline $\begin{array}{l}\text { H5 - A dimensão "Comprometimento com o Interesse } \\
\text { Público" influencia dimensão "Atração pela Formulação de } \\
\text { Políticas Públicas". }\end{array}$ & Modelagem de Equações Estruturais \\
\hline
\end{tabular}

De acordo com Hair et al. (2006), pressupõe-se que, para haver validade nomológica é necessário que as dimensões se correlacionem entre si, o que pode ser observado na matriz de correlação dos mesmos. Ela também pode ser baseada na correlação entre constructos não incluídos no mesmo modelo de mensuração.

Assim, as hipóteses apresentadas foram formuladas baseadas nestres dois pressupostos de validade nomológica, sendo que a hipótese 1 baseou-se no pressuposto da correlação entre constructos não pertencentes a um mesmo modelo de mensuração e as hipóteses restantes basearam-se no pressuposto de correlação entre as dimensões propostas para o modelo de mensuração a ser estimado. 
* Fase 3: empírica

Nesta fase, foram utilizadas as seguintes ferramentas estatísticas:

\section{Análise Fatorial}

A Análise Fatorial Exploratória procura sintetizar informações de um grande número de variáveis em um número menor de variáveis ou fatores. Para isso, identifica dimensões latentes e combina variáveis em fatores, para melhor compreensão dos dados (HAIR JR et al. 2006). Gerbing e Hamilton (1996, apud SEO, 2004) ${ }^{19}$ defendem o uso da técnica de análise fatorial como precursora da análise confirmatória e foi considerada como tal nesta pesquisa, uma vez que o instrumento de mensuração já existia . Assim, não foram utilizados os fatores extraídos pela análise fatorial e sim os fatores já predeterminados por Perry (1996) em seu estudo de construção/validação da escala de PSM.

Os índices dessa técnica avaliados para o desenvolvimento da próxima etapa foram: os testes de esfericidade de Bartlett e o KMO (testa a adequação da amostra com valor recomendado: $\mathrm{KMO} \geq 0,5$ ), a variância total explicada (percentagem total da variância que é explicada pelos fatores obtidos: recomendação de, no mínimo, $60 \%$, a não ser nas ciências sociais que este valor pode ser inferior) e as comunalidades (percentagem de variabilidade explicada de cada variável quando agrupada em fator: recomendação de, no mínimo, 50\%) (HAIR et al., 1998).

${ }^{19}$ SEO, D-C. Development and testing a model that explains contributing factors to unsafe work behavior. 2004. Tese ( Doutorado). Universidade de Indiana- Escola de Saúde, Educação Física e Recreação. Estados Unidos, 2004. 
Essa etapa do trabalho adequa a amostra que será utilizada nos padrões necessários para o prosseguimento da análise. Um outro padrão a ser considerado é a confiabilidade das dimensões. Para verificar a precisão do instrumento, foi utilizado o procedimento de análise da confiabilidade do mesmo.

Confiabilidade é um termo, segundo Pasquali (1999), que possui várias denominações tais como "consistência interna" e "fidedignidade", mas que indicam a mesma coisa: precisão. Sendo assim, fidedignidade ou confiabilidade referem-se ao quanto os escores de um indivíduo se repetem em situações diferentes. Alguns tipos de medidas de precisão são: testereteste, formas paralelas e consistência interna. Uma das medidas mais tradicionais de confiabilidade é o coeficience Alpha de Cronbach, que mede a consistência interna dos itens da escala. No presente estudo será utilizado o coeficiente Alpha de Cronbach para atestar a confiabilidade das dimensões da escala.

Hair et al. (1998) afirmam que, para validar os resultados de uma análise fatorial é necessária uma replicação em uma outra perspectiva: a confirmatória. Dessa forma, a análise fatorial confirmatória foi realizada juntamente com a técnica de modelagem de equações estruturais, apresentada a seguir. Uma observação se faz necessária neste momento: o estudo realizado por Perry (1996) contém somente as etapas de análise fatorial exploratória e confirmatória. Assim, o objetivo de validar a escala para as secretarias pesquisadas do município de Ribeirão Preto utilizando o mesmo processo da escala original é atingido ao final da etapa de análise fatorial confirmatória. O presente estudo, contudo, foi um pouco mais além, realizando a modelagem de equações estruturais que, segundo Hair et al. (2006), aplica a teoria especificando quais constructos são relacionados entre si e a natureza dessa relação. 


\section{Modelagem de Equações Estruturais}

É uma das ferramentas multivariadas, como a análise fatorial, a regressão múltipla, análise discriminante, entre outras. Estas técnicas possuem uma limitação comum: conseguem examinar somente uma relação entre variável dependente e independente por vez. A modelagem de equações estruturais, ao contrário, analisa várias relações de dependência simultaneamente (Hair et al., 2006). Essa técnica é muito útil quando o pesquisador deseja testar teorias que contenham múltiplas equações envolvendo relações de dependência e pode ser definida, de acordo com Hair et el. (2006, p.711) da seguinte forma:

a modelagem de equações estruturais estima uma série de equações de regressão múltipla separadas, mas interdependentes, simultaneamente, pela especificação do modelo estrutural usado pelo programa estatístico. Primeiro, o pesquisador baseia-se em teoria, experiência prévia e nos objetos da pesquisa, para distinguir quais variáveis independentes prevêem cada variável dependente.

Os mesmos autores afirmam que uma das premissas mais importantes da modelagem de equações estruturais é o tamanho da amostra, pois é sensível com relação à distribuição dos dados amostrais, principalmente quanto à normalidade. A estimação de máxima verossimilhança é a mais utilizada na avaliação dos modelos por ser o método de estimação que produz melhores resultados nos diferentes índices de ajuste total de modelos.

Estes índices de ajuste total do modelos são compostos por três tipos de medidas de qualidade de ajuste: 1) medida de ajuste absoluto; 2) medida de ajuste incremental e 3) medida de ajuste parcimoniosa (este somente no caso de comparação de modelos 
competitivos). Pelo menos um índice de cada uma dessas medidas deve estar presente na avaliação do ajuste total do modelo. A tabela 3 traz um resumo dos principais índices utilizados e seus valores de corte de acordo com o tamanho da amostra e número de variáveis observadas (HAIR ET AL., 2006; SEO, 2004).

- Teste qui-quadrado $\left(X^{2}\right)$ : o valor da diferença nas matrizes de covariância (observada e estimada) é a chave para a medida de ajuste geral de qualquer modelo de equações estruturais. O teste qui-quadrado provê um teste estatístico da diferença resultante. Os graus de liberdade (degrees of freedom) representam a quantidade de informação matemática disponível para estimar o modelo de parâmetros.

- CFI - Comparative Fit Index: é um índice que compara o modelo hipotético com o modelo independente (em que não existe correlações entre as variáveis).

- RMSEA - Root mean square error of approximation: esse índice calcula o erro de aproximação à população, considerando o número de parâmetros estimados e os graus de liberdade do modelo proposto.

- Normed Chi-Square: é um modelo em que se utiliza a razão $X^{2} /$ graus de liberdade. Geralmente, razões $X^{2} / \mathrm{df}$ no valor de 2 ou menos são associados com bons ajustes.

- SRMR - standardized residuasl: é a medida calculada para cada covariância possível. 
Tabela 3 - Resumo dos principais índices de ajuste de modelos e seus respectivos valores de corte de acordo com o tamanho da amostra e do número de variáveis observadas

\begin{tabular}{|c|c|c|c|c|c|c|}
\hline \multicolumn{4}{|c|}{$\mathrm{N}<\mathbf{2 5 0}$} & \multicolumn{3}{|c|}{$N>250$} \\
\hline $\begin{array}{cc} & \text { No. } \\
\text { Stat. } & \text { Var.(m) }\end{array}$ & $\mathrm{m} \leq 12$ & $12 \leq m \geq 30$ & $\mathbf{m} \geq \mathbf{3 0}$ & $\mathrm{m} \leq 12$ & $12 \leq m \geq 30$ & $\mathbf{m} \geq \mathbf{3 0}$ \\
\hline$X^{2}$ & $\begin{array}{l}\text { p-values } \\
\text { insignifican- } \\
\text { tes são } \\
\text { esperados }\end{array}$ & $\begin{array}{c}\text { p-values } \\
\text { significativos } \\
\text { podem } \\
\text { acontecer } \\
\text { mesmo com } \\
\text { um bom } \\
\text { ajuste }\end{array}$ & $\begin{array}{l}\text { p-values } \\
\text { significan- } \\
\text { tes são } \\
\text { esperados }\end{array}$ & $\begin{array}{c}\text { p-values } \\
\text { insignifican } \\
\text { tes podem } \\
\text { acontecer } \\
\text { mesmo } \\
\text { com um } \\
\text { bom ajuste }\end{array}$ & $\begin{array}{l}\text { p-values } \\
\text { significantes } \\
\text { podem ser } \\
\text { esperados }\end{array}$ & $\begin{array}{l}\text { p-values } \\
\text { significan } \\
\text { tes podem } \\
\text { ser } \\
\text { esperados }\end{array}$ \\
\hline CFI & $\geq .97$ & $\geq .90$ & $\geq .92$ & $\geq .95$ & $\geq .92$ & $\geq .90$ \\
\hline SRMR & $\begin{array}{c}\text { Pode ser } \\
\text { enviesada, } \\
\text { utilizar } \\
\text { outros } \\
\text { índices. }\end{array}$ & $\begin{array}{l}\leq .08 \text { com } \\
\text { CFI } \geq .95\end{array}$ & $\begin{array}{l}\leq .09 \text { com } \\
\text { CFI } \geq .92\end{array}$ & $\begin{array}{c}\text { Pode ser } \\
\text { enviesada, } \\
\text { utilizar } \\
\text { outros } \\
\text { índices. }\end{array}$ & $\begin{array}{l}\leq .08 \text { com } \\
\text { CFI } \geq .92\end{array}$ & $\begin{array}{l}\leq .08 \text { com } \\
\text { CFI } \geq .92\end{array}$ \\
\hline RMSEA & $\begin{array}{c}\text { Valores }<.08 \\
\text { com CFI } \geq \\
.97\end{array}$ & $\begin{array}{c}\text { Valores }<.08 \\
\text { com CFI } \geq \\
.95\end{array}$ & $\begin{array}{c}\text { Valores }< \\
.08 \text { com } \\
\text { CFI } \geq .92\end{array}$ & $\begin{array}{c}\text { Valores }< \\
.07 \text { com } \\
\text { CFI } \geq .97\end{array}$ & $\begin{array}{c}\text { Valores }<.08 \\
\text { com CFI } \geq \\
.92\end{array}$ & $\begin{array}{c}\text { Valores }< \\
.08 \text { com } \\
\text { CFI } \geq .90\end{array}$ \\
\hline $\mathrm{NCHI} / \mathrm{DF}$ & & & Menor d & ue 2 & & \\
\hline
\end{tabular}

Fonte: adaptado de Hair et al., 2006, p. 753 e Seo, 2004, pág. 87.

Nota: $\mathrm{m}=$ número de varáveis observadas; $\mathrm{N}=$ número de observações.

Todos estes índices foram utilizados na avaliação do ajuste geral dos modelos testados neste estudo, seguindo a sugestão de utilização de um índice diferente de cada tipo de medida, ou seja, um índice de medida de ajuste absoluto (RMSEA), um de medida de ajuste incremental (CFI) e o teste $X^{2}$ com seus graus de liberdade associados. No caso deste estudo, caso o teste de $X^{2}$ não apresente um valor de p satisfatório para a análise, será analisado em seu lugar o valor do Normed chi-square, que também é um índice utilizado para a avaliação do ajuste total do modelo.

Após avaliar o ajuste total do modelo, é necessário avaliar a unidimensionalidade e a confiabilidade de cada constructo do modelo. O termo unidimensional quer dizer que os indicadores de um determinado constructo se ajusta a um único fator, daí o conceito de unidimensionalidade. A confiabilidade é um elemento que indica a existência da 
unidimensionalidade, apesar de não garanti-la. Assim sendo, é essencial que o modelo ajustado apresente bons índices de confiabilidade. Uma medida seria a medida da variância extraída de cada indicador, pois ela reflete o total da variância explicada nos indicadores pelo constructo latente. Geralmente esse valor deve ser superior a .50 para um constructo (HAIR ET AL., 1998).

Ainda de acordo com Hair et al. (1998), uma outra estratégia de modelagem é a de modelos competitivos, também muito utilizada quando da comparação de resultados dos modelos para determinar qual deles possui o melhor ajuste. Os modelos competitivos denominados nested models são originados a partir de um modelo muito parecido, com apenas alguns ajustes diferentes. Esse tipo de modelo pode ser comparado ao modelo original

por meio do teste de diferença de $X^{2}\left(\Delta x^{2}\right)$. O valor $X^{2}$ de um modelo-base (B) é subtraído do valor $X^{2}$ de um modelo alternativo similar (nested) (A). Similarmente, a diferença em graus de liberdade é encontrada, com um grau de liberdade a menos para cada caminho adicional que é estimado. Dessa forma, o pesquisador decide, por comparação, qual modelo é mais adequado.

\section{Fase 4: inferências}

A partir dos resultados obtidos na fase 3, foram verificadas as hipóteses de pesquisa, assim como o ajuste total do modelo final. Com essa avaliação, conclui-se o processo de validação de constructo. 


\subsubsection{Esquema geral do processo de validação da escala do PSM}

O esquema do processo geral de validação da escala pode ser observado na figura 7:

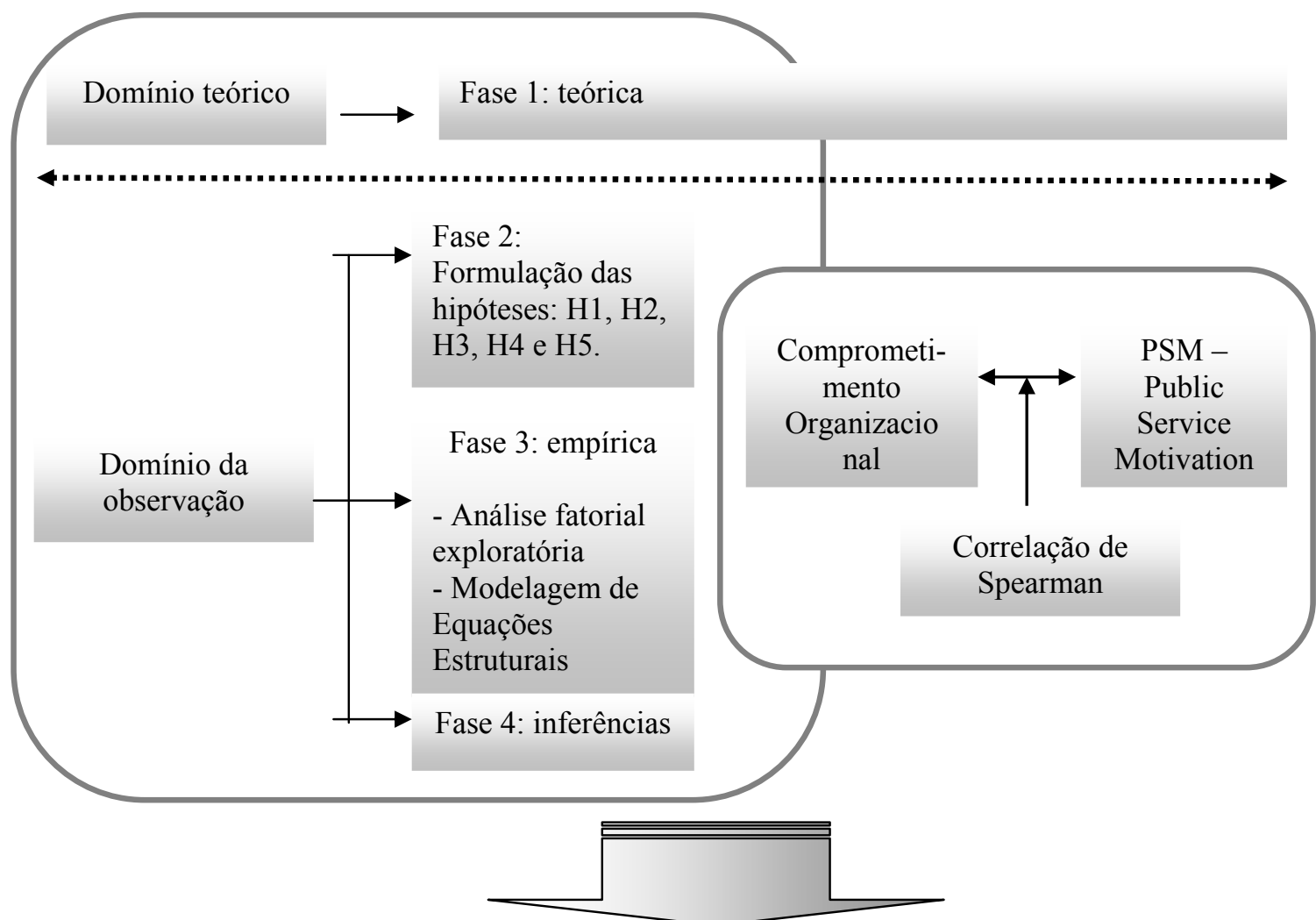

Validação de Constructo

Figura 7. Esquema do processo geral de validação da escala de PSM - Public Service Motivation 


\section{CAPÍTULO 7 - ANÁLISE E DISCUSSÃO DOS RESULTADOS}

Neste capítulo está a apresentação e análise dos resultados do processo de validade de constructo do PSM.

A apresentação desses resultados está subdividida em cinco unidades sendo que a primeira diz respeito à hipótese $1 \mathrm{e}$ as seguintes às hipóteses de 2 a 5 .

na primeira está exposto o teste da hipótese 1, por meio da análise de correlação de Spearman realizada entre os constructos do PSM e de Comprometimento Organizacional;

na segunda está exposta a análise exploratória dos componentes do PSM em que foi utilizada a análise fatorial exploratória a fim de verificar a adequação dos dados amostrais às ferramentas estatísticas que foram utilizadas;

na terceira, está exposta a análise confirmatória dos componentes do PSM para verificar se os indicadores de cada uma das dimensões latentes eram adequados aos mesmos;

na quarta, está exposta a análise confirmatória dos componentes do constructo do PSM a fim de verificar se o ajuste geral do modelo é adequado;

* na quinta está exposta a modelagem de equações estruturais realizada com o modelo originado da análise confirmatória a fim de verificar se a estrutura teórica é adequada para a amostra utilizada. 


\subsection{VALIDADE DE CONSTRUCTO}

\subsubsection{Análise da correlação entre os constructos do PSM e do Comprometimento}

\section{Organizacional.}

Como já citado anteriormente, a validade nomológica, segundo Hair et al. (2006) pode ser observada a partir da correlação entre constructos não necessariamente pertencentes a um mesmo modelo de mensuração. Assim, para o presente estudo, foi utilizado o constructo de Comprometimento Organizacional para o teste de validade nomológica. Primeiramente foram calculadas as médias e desvios-padrão para cada dimensão de cada um dos constructos (tabela 4):

Tabela 4 - Médias e desvios-padrão dos constructos de MSP e Comprometimento Organizacional e suas dimensões das dimensões

\begin{tabular}{l|c|c}
\hline \multicolumn{1}{c|}{ Dimensões PSM } & Média & $\begin{array}{c}\text { Desvio- } \\
\text { padrão }\end{array}$ \\
\hline Auto-sacrifício & 3,41 &, 822 \\
\hline Compaixão & 3,69 &, 768 \\
\hline Atração por formulação de políticas públicas & 2,58 & 1,096 \\
\hline Comprometimento com o interesse público & 3,77 &, 814 \\
\hline \multicolumn{1}{c|}{ Dimensões Comprometimento } & Média & $\begin{array}{c}\text { Desvio- } \\
\text { padrão }\end{array}$ \\
\hline Afetivo & 3,99 & 1,017 \\
\hline Instrumental Constructos & 4,21 & 1,195 \\
\hline Normativo & 4,19 & 1,072 \\
\hline MSP & Média & $\begin{array}{c}\text { Desvio- } \\
\text { padrão }\end{array}$ \\
\hline Comprometimento & 3,37 &, 698 \\
\hline
\end{tabular}


Posteriormente foi realizada uma análise de correlação de Spearman entre as dimensões e os constructos de Comprometimento Organizacional e de MSP. Como pode ser observado na tabela 5, apenas as dimensões da MSP "atração pela formulação de políticas públicas" e "comprometimento com o interesse público" apresentaram um coeficiente de correlação significativo com a dimensão “comprometimento Normativo" do Comprometimento Organizacional. A escala geral (constructo) da MSP também apresentou um valor significativo do coeficiente de correlação com relação à dimensão “comprometimento normativo" do Comprometimento Organizacional. As outras dimensões não apresentaram um coeficiente de correlação significativo, como também não apresentou as escalas gerais de MSP e de Comprometimento Organizacional.

Tabela 5 - Correlação de Spearman entre os constructos de MSP, de Comprometimento Organizacional e suas respectivas dimensões

\begin{tabular}{l|l|c|c|c|c}
\cline { 3 - 6 } \multicolumn{2}{l|}{} & Afetivo & $\begin{array}{c}\text { Instru } \\
\text { mental }\end{array}$ & $\begin{array}{c}\text { Norma } \\
\text { tivo }\end{array}$ & $\begin{array}{c}\text { Comprom. } \\
\text { Org. }\end{array}$ \\
\hline \multirow{2}{*}{ Auto-sacrifício } & $\begin{array}{l}\text { Coeficiente de } \\
\text { correlação }\end{array}$ &,- 030 &,- 089 &, 112 &, 017 \\
\cline { 2 - 6 } & Sig. (1-tailed) &, 342 &, 111 &, 063 &, 409 \\
\hline \multirow{2}{*}{ Compaixão } & $\begin{array}{l}\text { Coeficiente de } \\
\text { correlação }\end{array}$ &,- 070 &,- 075 &, 050 &,- 031 \\
\cline { 2 - 6 } & Sig. (1-tailed) &, 169 &, 152 &, 248 &, 338 \\
\hline \multirow{2}{*}{$\begin{array}{l}\text { Atração por formulação } \\
\text { de políticas públicas }\end{array}$} & $\begin{array}{l}\text { Coeficiente de } \\
\text { correlação }\end{array}$ &, 027 &,- 039 &, $137\left(^{*}\right)$ &, 050 \\
\cline { 2 - 6 } & Sig. (1-tailed) &, 358 &, 297 &, 030 &, 245 \\
\hline \multirow{2}{*}{$\begin{array}{c}\text { Comprometimento com } \\
\text { intesse público }\end{array}$} & $\begin{array}{l}\text { Coeficiente de } \\
\text { correlação }\end{array}$ &,- 064 &,- 034 &, $150\left(^{*}\right)$ &, 030 \\
\cline { 2 - 6 } & Sig. (1-tailed) &, 190 &, 319 &, 019 &, 343 \\
\hline \multirow{2}{*}{ MSP } & $\begin{array}{l}\text { Coeficiente de } \\
\text { correlação }\end{array}$ &,- 039 &,- 077 &, $142\left(^{*}\right)$ &, 022 \\
\cline { 2 - 6 } & Sig. (1-tailed) &, 299 &, 145 &, 025 &, 383 \\
\hline
\end{tabular}

** A correlação é significativa no nível de 0.01 (1-tailed).

* A correlação é significativa no nível de 0.05 (1-tailed). 
Estatisticamente, a H1: Existe correlação entre os constructos do PSM e do Comprometimento Organizacional não foi confirmada; porém, com base nos coeficientes apresentados entre as dimensões e a escala já citadas anteriormente e também nos estudos que afirmam existir essa correlação, não se pode rejeitar essa hipótese. Ao contrário, estes resultados devem servir como dados iniciais e exploratórios para outras investigações a fim de encontrar a melhor escala que represente de forma mais significativa esta relação.

A seguir, são apresentadas as unidades dos resultados obtidos das outras análises realizadas a fim de testar o modelo confirmatório e estrutural da teoria do PSM.

\subsubsection{Análise exploratória dos componentes do PSM - Public Service Motivation}

Seguindo a defesa de Gerbing e Hamilton (1996, apud SEO, 2004) ${ }^{20}$ com relação ao uso da técnica de análise fatorial como precursora da análise confirmatória, serão apresentados os resultados desta fase. Como citado anteriormente, neste estudo não foram utilizados os fatores extraídos pela análise fatorial e sim os fatores já pré-determinados por Perry (1996) em seu estudo de construção/validação da escala.

A amostra apresentou um valor para o índice KMO (medida de adequação) de 0,852 e o teste de esfericidade de Bartlett apresentou um valor de $\mathrm{p}<0,005$ (figura 8); a variância total explicada foi de aproximadamente $60,2 \%$; todos os valores apresentaram-se dentro dos parâmetros considerados como significativos.

\footnotetext{
${ }^{20}$ SEO, D-C. Development and testing a model that explains contributing factors to unsafe work behavior. 2004. Tese ( Doutorado). Universidade de Indiana- Escola de Saúde, Educação Física e Recreação. Estados Unidos, 2004.
} 
KMO and Bartlett's Test

\begin{tabular}{|c|c|c|}
\hline \multicolumn{2}{|c|}{$\begin{array}{l}\text { Kaiser-Meyer-Olkin Measure of Sampling } \\
\text { Adequacy. }\end{array}$} & 852, \\
\hline $\begin{array}{l}\text { Bartlett's Test of } \\
\text { Sphericity }\end{array}$ & $\begin{array}{l}\text { Approx. Chi-Square } \\
\text { df } \\
\text { Sig. }\end{array}$ & $\begin{array}{r}1243,364 \\
276 \\
, 000\end{array}$ \\
\hline
\end{tabular}

\section{Figura 8. Índices para avaliar a adequação da amostra}

Os índices de comunalidade dos indicadores são relevantes no que diz respeito à adequação da amostra para a análise confirmatória posterior, assim como o número de fatores extraídos. Segundo Hair et al. (2006), uma amostra pode ser definida com 100 a 150 observações caso tenha no máximo 5 constructos, com no mínimo 3 indicadores para cada um e com comunalidades com um valor considerado alto (.6 ou mais); a amostra pode também ser definida com 200 observações se o valor das comunalidades for mais modesto (.45 a .55) ou se os constructos possuírem menos de 3 indicadores cada.

No caso do presente estudo, a amostra caracterizou-se com 190 observações, sendo admissível da forma em que se apresentou, uma vez que não será a utilizada a estrutura de fatores extraídos na etapa exploratória; os valores para as comunalidades estão apresentados na figura 9: 


\begin{tabular}{|c|c|c|}
\hline Variável & Initial & Extraction \\
\hline 1_Auto-sacríficio & 1,000 &, 676 \\
\hline 2_Compaixão & 1,000 & ,722 \\
\hline 3 _Compaixão & 1,000 & ,665 \\
\hline 4_Compaixão & 1,000 & 643 \\
\hline 5_Auto-sacrificio & 1,000 & ,642 \\
\hline 6_Auto-sacrificio & 1,000 & ,536 \\
\hline 7 Compaixão & 1,000 &, 500 \\
\hline 8_Auto-sacrificio & 1,000 & ,507 \\
\hline 9_Compaixão & 1,000 & ,616 \\
\hline $\begin{array}{l}\text { 10_Atração por } \\
\text { formulação de politicas } \\
\text { pulbicas }\end{array}$ & 1,000 & ,621 \\
\hline 11_Auto-sacrificio & 1,000 & ,639 \\
\hline 12_Compaixão & 1,000 & ,519 \\
\hline $\begin{array}{l}\text { 13_Comprometimento } \\
\text { com o interesse publico }\end{array}$ & 1,000 & ,529 \\
\hline 14_Auto-sacrifício & 1,000 & ,507 \\
\hline 15_Auto-sacrificio & 1,000 & ,566 \\
\hline $\begin{array}{l}\text { 16_Comprometimento } \\
\text { com o interesse publico }\end{array}$ & 1,000 & ,609 \\
\hline 17_Compaixão & 1,000 & ,623 \\
\hline 18_Auto-sacrifício & 1,000 & ,584 \\
\hline $\begin{array}{l}\text { 19_Atração por } \\
\text { formulação de politícas } \\
\text { pulbicas }\end{array}$ & 1,000 & ,633 \\
\hline $\begin{array}{l}20 \text { Comprometimento } \\
\text { com o interesse publico }\end{array}$ & 1,000 & ,604 \\
\hline $\begin{array}{l}21 \text { Atração por } \\
\text { formulação de politicas } \\
\text { pulbicas }\end{array}$ & 1,000 & 693 \\
\hline $\begin{array}{l}22 \text { Comprometimento } \\
\text { com o interesse publico }\end{array}$ & 1,000 & ,565 \\
\hline $\begin{array}{l}23 \text { Comprometimento } \\
\text { com o interesse publico }\end{array}$ & 1,000 & 672 \\
\hline 24_Compaixão & 1,000 &, 569 \\
\hline
\end{tabular}

Figura 9. Comunalidades para os indicadores da análise fatorial exploratória

Como pode ser observado na figura 9 , dez indicadores apresentaram valores abaixo de 0.60, apesar de que poucos destes estão muito abaixo desse valor. Todos os outros apresentaram valores acima de 0.60 , sendo portanto, admissíveis.

Considerando os parâmetros colocados por Hair et al. (2006) como necessários para a definição da amostra, assim como uma das premissas principais da modelagem de equações estruturais que afirma a necessidade de o pesquisador não se desviar do seu embasamento teórico e os resultados da análise fatorial exploratória dos dados amostrais, os mesmos foram considerados adequados, tanto pelo número de observações quanto por terem apresentado 
índices dentro dos parâmetros exigidos. Assim, a próxima etapa apresentada é a análise confirmatória dos componentes do PSM.

\subsubsection{Análise confirmatória dos componentes do PSM - Public Service Motivation}

Medsker, Williams e Holand (1994, apud MEDEIROS, 2003, p. 90) ${ }^{21}$ recomendam que seja realizada uma análise fatorial confirmatória entre as variáveis e seus indicadores, antes da modelagem de equações estruturais. Sendo assim, esse foi o procedimento adotado neste estudo, com as variáveis latentes do modelo e seus respectivos indicadores.

O tipo de matriz (de covariância ou de correlação) a ser utilizado na análise do resultado pode ser escolhido pelo pesquisador. Assim, o resultado obtido pela utilização da técnica de estimação da máxima verossimilhança, foi especificado para dados padronizados, a partir de uma matriz de correlação, pela maior facilidade de interpretação desses dados.

Além disso, foi realizada uma análise da consistência interna por meio do cálculo do Alpha de Cronbach. Foi medida a consistência interna entre os indicadores de cada dimensão latente e também se essas consistências melhorariam caso algum deles fosse eliminado de seu constructo.

\footnotetext{
${ }^{21}$ MEDSKER, G. J., WILLIAMS, L. J., HOLAHAN, P. J. A review of current practices for evaluating causal models in organizational behavior and human resource management research. Journal of Management. 20 (2), 439-64, 1994.
} 
As medidas de avaliação de ajuste utilizadas nessa etapa foram o CFI - comparative fit index e o RMSEA - root mean square error of approximation:, adequados para estimativas baseadas na matriz de correlação (HAIR ET AL., 1998).

\subsubsection{Avaliação do ajuste das dimensões latentes do PSM}

Como citado anteriormente, serão apresentados a seguir as medidas de ajuste para as quatro dimensões latentes do constructo do PSM: auto-sacrifício, compaixão, comprometimento com o interesse público e atração pela formulação de políticas públicas.

A dimensão latente auto-sacrificio apresenta um bom ajuste quando avaliada pelos índices de ajuste utilizados (figura 10). Seu CFI apresentou um valor de 0,969, superior ao parâmetro estabelecido por Hair et al. (1998) e seu RMSEA apresentou um valor de 0,045, menor do que os 0,08 recomendados pelos mesmos autores. Os indicadores dessa dimensão apresentaram um Alpha de Cronbach de 0,762, sendo que a exclusão de qualquer um desses indicadores não acarretaria um aumento neste índice. 


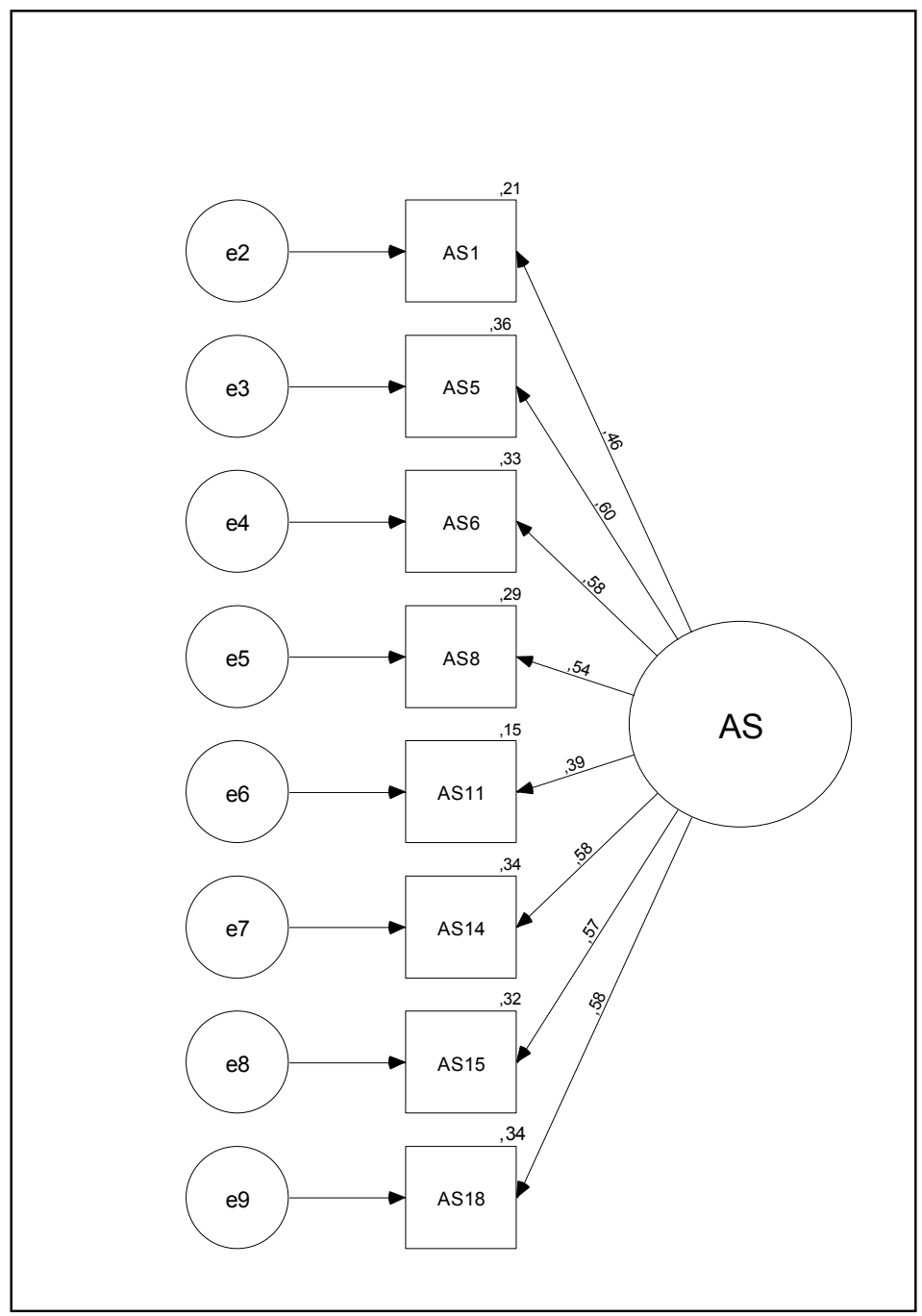

Figura 10. Dimensão latente Auto-sacrifício

A dimensão latente Compaixão apresenta um bom ajuste quando avaliada pelos índices de ajuste utilizados (figura 11). Seu CFI apresentou um valor de 0,927, superior ao parâmetro estabelecido por Hair et al. (1998) e seu RMSEA apresentou um valor de 0,062, menor do que os 0,08 recomendados pelos mesmos autores. Os indicadores dessa dimensão apresentaram um Alpha de Cronbach de 0,723, sendo que a exclusão de qualquer um desses indicadores não acarretaria um aumento neste índice. 


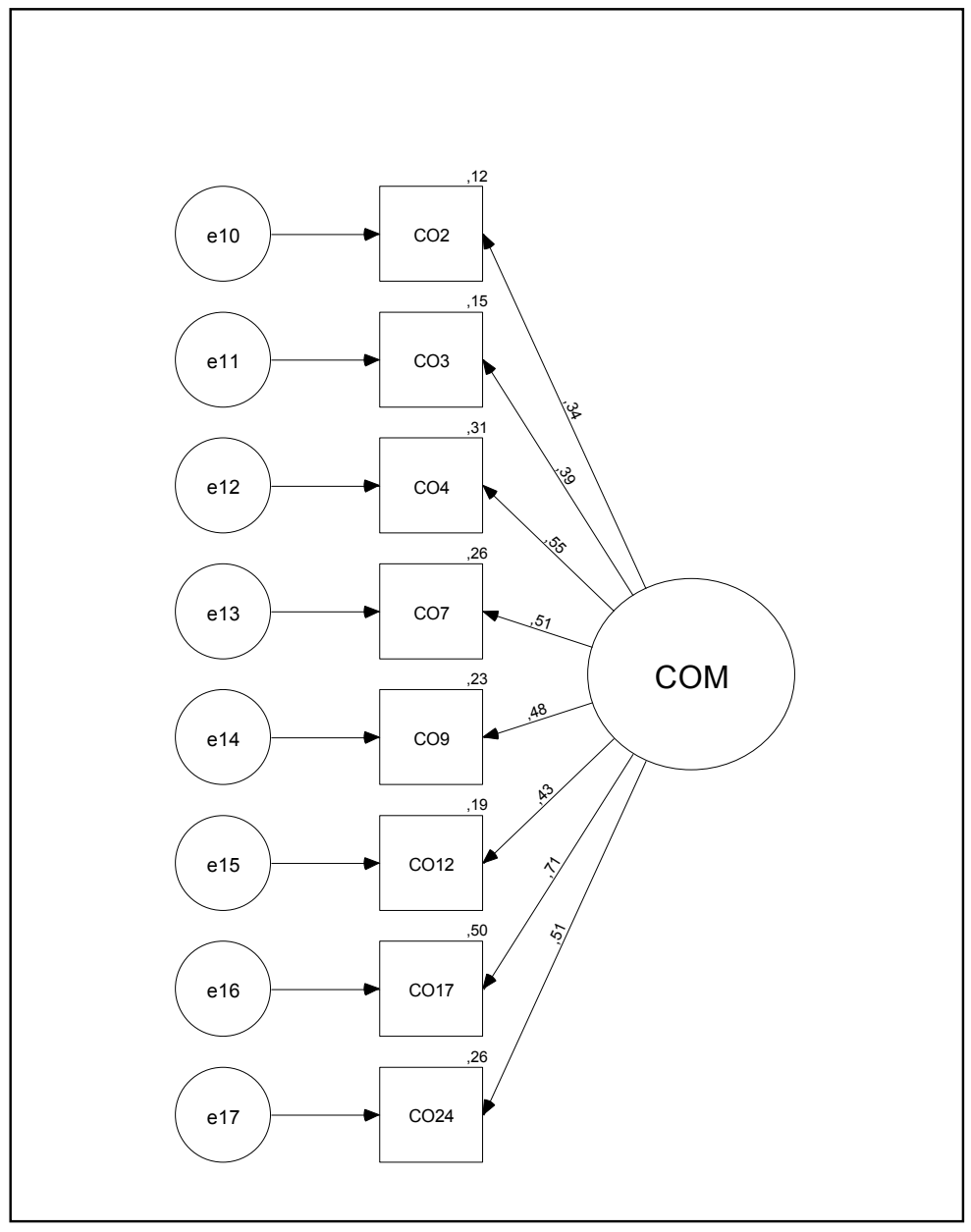

Figura 11. Dimensão latente Compaixão

A dimensão latente Comprometimento com o interesse público apresenta um bom ajuste quando avaliada pelos índices de ajuste utilizados (figura 12). Seu CFI apresentou um valor de 0, 945, superior ao parâmetro estabelecido por Hair et al. (1998) e seu RMSEA apresentou um valor de 0,093. O valor do CFI se apresentou acima do parâmetro da tabela 3; porém, de forma geral, os valores abaixo de 0,10 são considerados pelos autores citados acima como admissíveis para a maioria dos modelos com outros bons índices de ajuste. Assim, não foi feito nenhum reajuste, como excluir algum indicador, por exemplo, a fim de considerar esta dimensão tal qual foi apresentada na escala original. Os indicadores dessa dimensão 
apresentaram um Alpha de Cronbach de 0,717 , sendo que a exclusão de qualquer um desses indicadores não acarretaria um aumento neste índice.

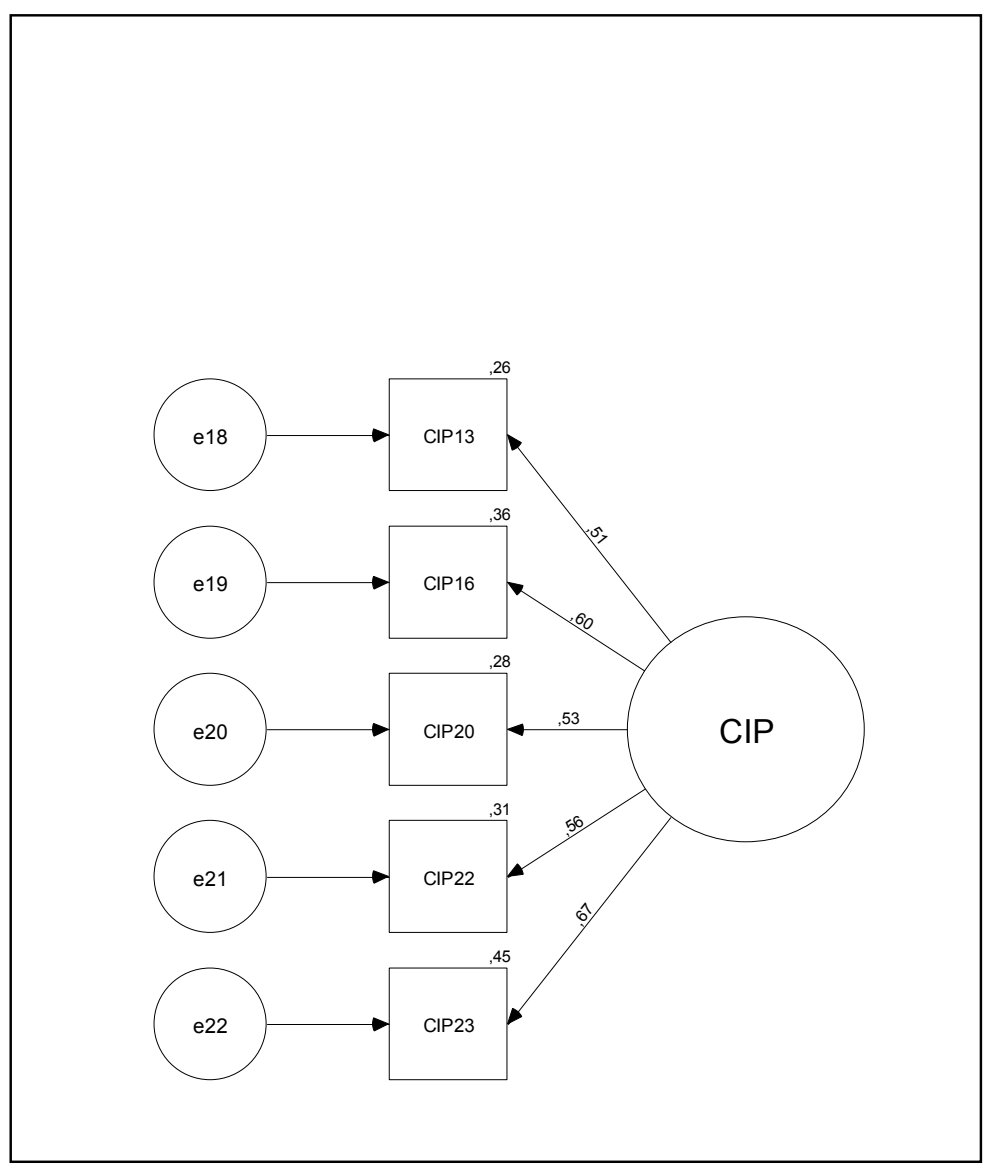

Figura 12. Dimensão latente Comprometimento com o interesse público

A dimensão latente Atração pela formulação de políticas públicas apresentou um erro durante a sua análise confirmatória: o valor de uma variância apresentou-se negativo, o que configura um erro de estimação. A figura 13 apresenta o output do AMOS com o resultado da primeira análise. 
Notes for Model (Group number 1 - Default model)

The following variances are negative. (Group number 1

- Default model)

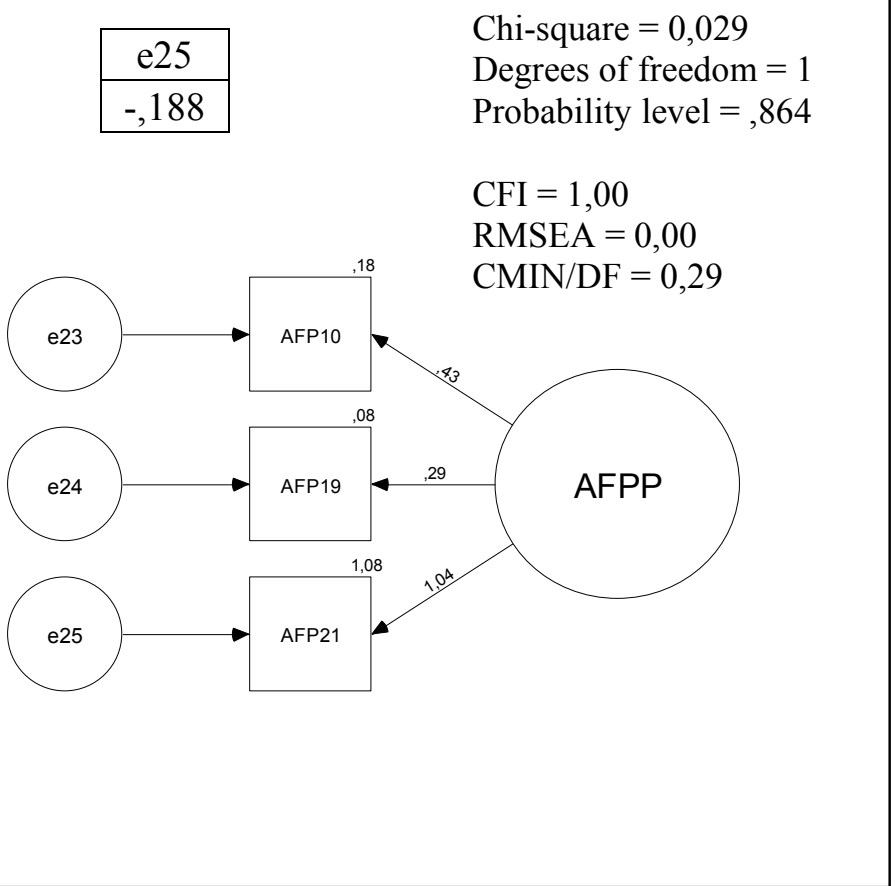

\section{Figura 13. Output do Amos com o resultado da primeira análise confirmatória para a dimensão latente Atração pela formulação de políticas públicas}

De acordo com Hair et al. (2006), a ocorrência de valores de variância negativos é denominada Casos Heywood e é corrigida eliminando o indicador ou restringindo o erro de mensuração para um valor positivo pequeno. Seguindo a recomendação dos autores, o valor do erro de mensuração foi restrito a 0,005 e foi realizada uma outra avaliação do ajuste.

Após a realização da restrição recomendada pelos autores, houve um bom ajuste das medidas, quando avaliada pelos índices de ajuste utilizados. Seu CFI apresentou um valor de 1, 0, superior ao parâmetro estabelecido por Hair et al. (1998) e seu RMSEA apresentou um 
valor de 0,00 menor do que os 0,08 recomendados pelos mesmos autores. Os indicadores dessa dimensão apresentaram um Alpha de Cronbach de 0,551; esse é um valor considerado aceitável, mas baixo. A exclusão da variável 19 aumentaria esse valor para 0,612, melhorando seu indicador de consistência interna. Apesar dessa melhora, optou-se por não realizar essa exclusão, uma vez que a intenção neste estudo é testar a validade da escala tal qual foi concebida originalmente.

Esta dimensão foi a única que apresentou medidas de ajuste que tiveram que ser refeitas, pois sem este reajuste, não seria possível passar para a etapa seguinte; da mesma forma, foi a única que apresentou um Alpha de Cronbach baixo. Essa situação pode ser explicada pelo fato de que a amostra utilizada se encontra em um nível hierárquico administrativo, ou seja, a realidade de tomada de decisão e desenvolvimento de políticas públicas não é muito próxima do seu cotidiano.

\subsubsection{Análise fatorial confirmatória entre os componentes do PSM - Public Service Motivation}

O primeiro modelo testado é o mesmo modelo do estudo americano, ou seja, com quatro dimensões latentes: auto-sacrifício, compaixão, comprometimento com o interesse público e atração pela formulação de políticas públicas. As análises confirmatórias realizadas demonstram que os indicadores são adequados para medir suas respectivas dimensões latentes, como pode ser observado na tabela 6. 
Tabela 6 - Resultado da modelagem de equações estruturais - Modelo 1

\begin{tabular}{|c|c|c|c|}
\hline \multicolumn{3}{|c|}{ Parâmetros do modelo } & \multirow{2}{*}{$\begin{array}{c}\begin{array}{c}\text { Coef. } \\
\text { padronizados }\end{array} \\
, 580^{*} \\
\end{array}$} \\
\hline PSM18_A & $<---$ & $\mathrm{AS}$ & \\
\hline PSM15_A & $<---$ & AS &, $567^{*}$ \\
\hline PSM14_A & $<--$ & AS &, $583^{*}$ \\
\hline PSM11_A & $<--$ & AS & ,393* \\
\hline PSM8_A_A & $<--$ & AS &, $541 *$ \\
\hline PSM6_A_A & $<---$ & $\mathrm{AS}$ &, $576^{*}$ \\
\hline PSM5_A_A & $<---$ & $\mathrm{AS}$ & ,599* \\
\hline PSM1_A_A & $<---$ & $\mathrm{AS}$ & ,464* \\
\hline PSM24_A & $<---$ & $\mathrm{COM}$ &, $506^{*}$ \\
\hline PSM17_A & $<---$ & $\mathrm{COM}$ &, $708^{*}$ \\
\hline PSM12_A & $<--$ & COM &, $431 *$ \\
\hline PSM9_C_A & $<--$ & $\mathrm{COM}$ &, $479 *$ \\
\hline PSM7_C_A & $<---$ & $\mathrm{COM}$ &, $510 *$ \\
\hline PSM4_C_A & $<---$ & $\mathrm{COM}$ &, $553 *$ \\
\hline PSM3_C_A & $<--$ & $\mathrm{COM}$ & ,387* \\
\hline PSM2_C_A & $<--$ & $\mathrm{COM}$ & ,340* \\
\hline PSM23_A & $<---$ & CIP & ,668* \\
\hline PSM22_A & $<--$ & CIP &, $560 *$ \\
\hline PSM20_A & $<--$ & CIP &, $533 *$ \\
\hline PSM16_A & $<---$ & CIP &, $599 *$ \\
\hline PSM13_A & $<---$ & CIP &, $509 *$ \\
\hline PSM21_A & $<---$ & AFPP & ,989* \\
\hline PSM19_A & $<---$ & AFPP & ,306* \\
\hline PSM10_A & $<---$ & AFPP & ,449* \\
\hline PSM & $<--$ & AS & ,348* \\
\hline PSM & $<--$ & $\mathrm{COM}$ &, $337 *$ \\
\hline PSM & $<---$ & CIP & ,360* \\
\hline PSM & $<---$ & AFPP &, $661^{*}$ \\
\hline
\end{tabular}

$* \mathrm{p}<0,01$

Esse primeiro modelo apresentou um bom ajuste quando avaliado pelas medidas de ajuste geral (figura 14): O Normed chi-square apresentou um valor menor do que 2; o RMSEA apresentou um valor de 0,068; o SRMR apresentou um valor de 0,0781 e o CFI apresentou um valor de 0,81 . 
Chi-square $=459,793$

Degrees of freedom $=247$

(e2) $\longrightarrow$ (e3)

Probability level $=, 000$

$\mathrm{CFI}=0,81$

RMSEA $=0,068$

$\mathrm{CMIN} / \mathrm{DF}=1,862$

(e5) $\rightarrow$ AS8 -57

SRMR $=0,0781$

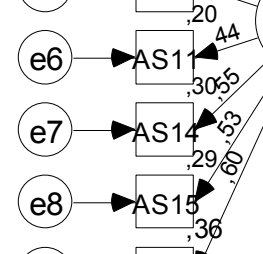

(e9) $\rightarrow A S 18$

$\left(\mathrm{e} 10 \rightarrow \mathrm{CO}_{, 10}^{, 12}\right.$

(e11) $\rightarrow \mathrm{CO}_{24}$

(12) $\rightarrow-\mathrm{CO}^{3} \mathrm{C}_{0}$

(13) $\rightarrow 507$

(14) $\rightarrow \cos ^{48}$ COM

(e15) $-\operatorname{co1}_{2}^{230^{\circ}}$

(e16 $\rightarrow$ - 17

(16) $\longrightarrow \mathrm{CO1}$

e17 $\rightarrow \mathrm{CO} 24$

(118) ${ }^{212} 13$

(e19) $\quad$ CIP16. 16

AS
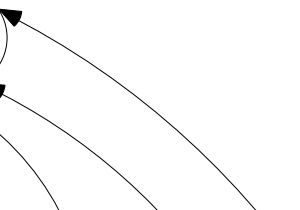

(e20) CIP20 49 CIP

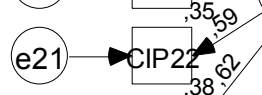

(22) $\longrightarrow$ CIP25

20

(e24) AFP1 $A 1^{31}$ AFPP

(25) $\triangle \mathrm{AFP} 2$

Figura 14. Modelo 1 com quatro dimensões latentes do PSM 
Apesar do CFI não ter apresentado um valor acima do recomendado $(0,90)$, ficou muito próximo tanto desse valor quanto do valor encontrado por Perry (1996), como apresentado na tabela 7. Os índices utilizados pelo autor não foram os mesmo utilizados no presente estudo, mas indicam o ajuste do modelo da mesma maneira. Além disso, foram avaliadas outras medidas de ajuste geral não consideradas no trabalho de Perry. Os valores do $x^{2}$ e $d f$ foram muito próximos e o $p$-value foi o mesmo para os dois modelos; como o modelo brasileiro apresentou um $\mathrm{p}<0,005$, o índice normed chi-squared (CMIN/DF) foi avaliado na análise, uma vez que o teste de $x^{2}$ é sensível a não normalidade dos dados amostrais (HAIR ET AL., 2006).

Tabela 7 - Comparação das medidas de ajuste do modelo (1) americano e do brasileiro

\begin{tabular}{l|c|c|c|c|c|c|c|c|c}
\hline Modelo & $\boldsymbol{x}^{2}$ & Df & p- & GFI & AGFI & CFI & RMSEA & SRMR & CMIN/DF \\
\hline M1A & 596,15 & 249 &, 000 & .88 & .86 & - & - & - & - \\
\hline M1B & 459,793 & 246 &, 000 & - & - & .815 & .067 & 0,0781 & 1,842 \\
\hline
\end{tabular}

Nota: M1A - modelo 1 americano / M1B - modelo 1 brasileiro

De acordo com Cooper e Schindler (2003), a validade convergente deve ser analisada, ou seja, se há correlação entre as dimensões latentes. Quando essa correlação ultrapassa o coeficiente de 0.90 , é recomendado que as variáveis que apresentaram um coeficiente acima desse valor sejam unidas em uma única variável. Assim, Perry (1996) formulou um modelo alternativo ao primeiro (modelo 2), unindo as dimensões auto-sacrificio e comprometimento com o interesse público, pois estas apresentaram um coeficiente de correlação de 0,89 . Apesar de o maior coeficiente de correlação do modelo 1 brasileiro ter sido entre as dimensões compaixão e comprometimento com o interesse público (Tabela 8), o modelo 2 testado foi o mesmo proposto por Perry (1996) para fins de comparação. 
Tabela 8 - Coeficientes de correlação entre as dimensões latentes do modelo 1

\begin{tabular}{l|c}
\hline \multicolumn{1}{c|}{ Dimensões } & Coef. Cor. \\
\hline AFPP $<-->$ AS &, 382 \\
\hline AS $<-->$ COM &, 903 \\
\hline COM $<-->$ CIP &, 952 \\
\hline AFPP $<-->$ CIP &, 272 \\
\hline AS $<-->$ CIP &, 900 \\
\hline AFPP $<-->$ COM &, 305
\end{tabular}

O segundo modelo estimado (modelo 2), portanto, é composto por três dimensões latentes: auto-sacrifício + comprometimento com o interesse público, compaixão e atração pela formulação de políticas públicas.

O modelo 2 também apresentou um bom ajuste quando avaliado pelas medidas de ajuste (figura 15): O Normed chi-square apresentou um valor menor do que 2; o RMSEA apresentou um valor de 0,068; o SRMR apresentou um valor de 0,0785 e o CFI apresentou um valor de 0,805 .

Para os modelos americano e brasileiro (2), assim como nos primeiros modelos testados, os valores do $x^{2}$ e $d f$ foram muito próximos e o $p$-value foi o mesmo tanto para um quanto para o outro; como ele apresentou um $\mathrm{p}<0,005$, o índice normed chi-squared (CMIN/DF) foi considerado na análise com um valor dentro do recomendado. 


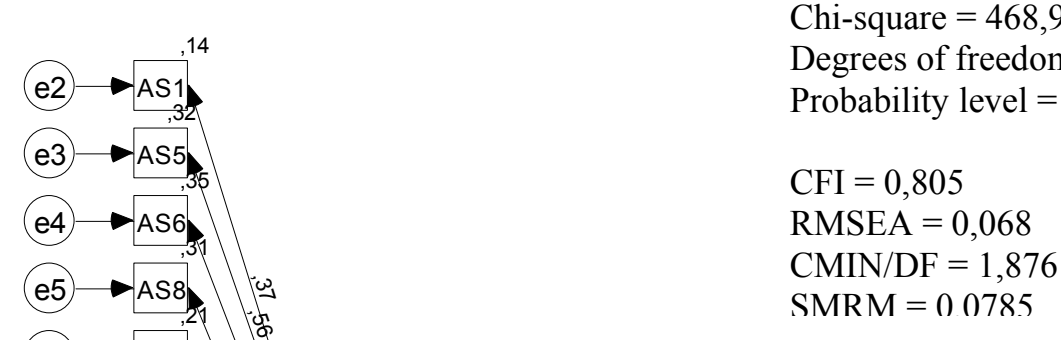

Chi-square $=468,927$

Degrees of freedom $=250$

ence $=, 000$

(e6) $\rightarrow$ AS1

(e7) $\rightarrow A S 17$ हू

(e8) $\rightarrow$ AS15

(e9) $\frac{-A_{28} 53^{59}}{{ }_{2}^{5}}$

AS

(e18) $\quad \mathrm{CIP} 13_{39,62}^{4}$

(19) $-115,58$

(e20 $\rightarrow$ CIP20

(e21) $\rightarrow$ CIP2

(22) $\longrightarrow$ CIP23

(e10) $\rightarrow \mathrm{CO}_{10}^{, 12}$

(11) $\rightarrow \mathrm{CO}_{24}$

$(12) \rightarrow \frac{\mathrm{CO} 4}{35} \times$

e13 $\rightarrow \cot -59$

(14) $\cos ^{48} \mathrm{COM}^{\circ}$

(15) $\rightarrow-\operatorname{co1}_{45}^{2}$

(e16) $\rightarrow 201$

(e17) $\rightarrow \mathrm{CO}_{20}$

(23) AFP1 12

(24) AFP1 31 AFPP

(e25) $\triangle \mathrm{FP}_{2}$

Figura 15. Modelo 2 com três dimensões latentes do PSM 
Da mesma forma que o modelo 1, no modelo 2, o CFI não apresentou um valor acima do recomendado $(0,90)$, mas ficou muito próximo tanto desse valor quanto do valor encontrado por Perry (1996). A comparação dos valores do teste $x^{2}$ e das medidas de ajuste geral dos modelos alternativos (modelo 2) americano e brasileiro pode ser observada na tabela 9:

Tabela 9 - Comparação das medidas de ajuste do modelo (2) americano e do brasileiro

\begin{tabular}{l|c|c|c|c|c|c|c|c|c}
\hline Modelo & $\boldsymbol{x}^{2}$ & df & p- & GFI & AGFI & CFI & RMSEA & SRMR & CMIN/DF \\
\hline M2A & 576,82 & 246 &, 000 & .88 & .86 & - & - & - & - \\
\hline M2B & 468,927 & 250 &, 000 & - & - & .805 & .068 & 0,0785 & 1,876 \\
\hline
\end{tabular}

Nota: M2A - modelo 2 americano / M2B - modelo 2 brasileiro

\subsubsection{Comparação dos modelos americano e brasileiro estimados}

No estudo de validação da escala original, Perry (1996) chegou às seguintes conclusões:

O modelo 1 (de quatro dimensões) não é significativo de acordo com o teste estatístico do $x^{2}$, em que o objetivo seria atingir um $\mathrm{p}>0,005$; esse teste, como já foi mencionado anteriormente, é muito sensível ao número de casos, aos requerimentos de termos de erros não correlacionados e também à unidimensionalidade. As medidas de ajuste geral utilizadas pelo autor GIF - goodness of fit index e AGIF - adjusted goodness of fit index apresentaram valores de, respectivamente, 0,88 e 0,86 considerados pelo mesmo admissíveis.

O modelo 2 estimado (de três dimensões) também não é significativo de acordo com o teste estatístico do $x^{2}$, mas apresentou boas medidas de ajuste geral GIF e AGIF, idênticos aos índices do modelo 1. Como as medidas de ajuste geral dos dois modelos foram muito 
parecidas, o teste de diferença do $\Delta x^{2}$ foi realizado $\left(x^{2}=19,23, \mathrm{df}=3\right.$ e $\left.\mathrm{p}<0,005\right)$ e indicou o modelo 1 como o mais adequado.

Os coeficientes de consistência interna Alpha de Cronbach de todas as subescalas variaram de 0,69 a 0,74 , corroborando com os resultados encontrados na análise fatorial confirmatória, de acordo com Perry (1996). Em sua discussão sobre o processo de validação da escala, o autor indica alguns pontos de refinamento da mesma. Um desses pontos destacados por ele é a dimensionalidade da escala, por causa da pequena diferença entre os modelos propostos. A opção de se manter a dimensão de auto-sacrificio foi baseada na conexão histórica do pensamento americano sobre o serviço público. Apesar disso, o modelo de três dimensões coincide com o as dimensões motivacionais racional, baseado em normas e afetiva de Knoke e Wright-Isak (1982, apud Perry, 1996, p. 20) ${ }^{22}$. Dessa forma, esse modelo não pode ser desconsiderado como um resultado empírico relevante.

O autor conclui, portanto, que baseado no processo de desenvolvimento da análise estatística, a escala de PSM apresentada em seu estudo possui uma boa validade geral de face, de constructo e discriminante entre os quatro fatores que compõem as dimensões latentes, além de um alto índice de precisão.

Analisando pelo mesmo prisma apresentado acima, os resultados para os modelos propostos para a amostra pesquisada podem ser avaliados da seguinte forma:

Os coeficientes de consistência interna Alpha de Cronbach de todas as subescalas variaram de 0,55 a 0,76 . O modelo 1 (de quatro dimensões) não é significativo de acordo com o teste estatístico do $x^{2}$, em que o objetivo seria atingir um $\mathrm{p}>0,005$, mas o Normed chi-

\footnotetext{
${ }^{22}$ KNOKE, D., WRIGHT-ISAK, C. Individual motives and organizational incentive systems. Research in the sociology of organization. v.1, p. 209-54, 1982.
} 
squared apresentou um valor relevante $(<2)$ para um bom ajuste do modelo, assim como as outras medidas de ajuste geral encontradas.

O modelo 2 (de três dimensões) estimado também não é significativo de acordo com o teste estatístico do $x^{2}$, em que o objetivo seria atingir um $\mathrm{p}>0,005$, mas também apresentou um valor do Normed chi-squared menor do que 2, além de boas medidas de ajuste geral. Como as medidas de ajuste geral dos dois modelos foram muito parecidas também no caso da amostra, o teste de diferença do $\Delta x^{2}$ foi realizado $\left(x^{2}=9,13, \mathrm{df}=3\right.$ e $\left.\mathrm{p}<0,005\right)$ indicando o modelo 1 como o mais adequado.

O resumo dos valores do teste $x^{2}$, das medidas de ajuste geral e do teste de diferença de $\mathrm{x}^{2}\left(\Delta \mathrm{x}^{2}\right)$ de todos os modelos estimados estão apresentados na tabela 10 .

Tabela 10 - Resumo dos valores do teste $x^{2}$ e das medidas de ajuste dos modelos americano e brasileiro

\begin{tabular}{l|c|c|c|c|c|c|c|c|c}
\hline \multicolumn{1}{c|}{ Modelo } & $\mathbf{x}^{2}$ & $\mathbf{d f}$ & $\mathbf{p}$ & GFI & AGFI & CFI & RMSEA & SRMR & CMIN/DF \\
\hline M1A & 596,15 & 249 &, 000 & .88 & .86 & - & - & - & - \\
\hline M2A & 576,82 & 246 &, 000 & .88 & .86 & - & - & - & - \\
\hline M1B & 459,79 & 247 &, 000 & - & - & .815 & .067 & 0,0781 & 1,842 \\
\hline M2B & 468,93 & 250 &, 000 & - & - & .805 & .068 & 0,0785 & 1,876 \\
\hline$\Delta \mathbf{x}^{2}$ M2A-M1A & 19,23 & 3 & - & - & - & - & - & - & - \\
\hline$\Delta \mathbf{x}^{2}$ M2B-M1B & 9,13 & 3 & - & - & - & - & - & - & - \\
\hline
\end{tabular}

Nota:

M1A - modelo 1 americano / M1B - modelo 1 brasileiro M2A - modelo 2 americano / M2B - modelo 2 brasileiro 


\subsubsection{Modelagem de equações estruturais com os componentes da escala de MSP - Motivação no Serviço Público}

A transição de um modelo de mensuração para um modelo estrutural significa a aplicação da teoria estrutural em termos de relações entre constructos. Um modelo de mensuração contém tipicamente todos os constructos com relações não causais ou correlacionais entre si. O modelo estrutural aplica a teoria estrutural especificando quais constructos são relacionados entre si e qual a natureza dessa relação (HAIR ET AL., 2006).

Os mesmos autores recomendam um processo de dois passos para a MEE Modelagem de Equações Estruturais, em que no primeiro passo são testados o ajuste e a validade de constructo e no segundo passo é testada a teoria estrutural. Até o presente momento, neste estudo, portanto, foi realizado o primeiro passo (por meio da AFE - Análise Fatorial Exploratória), atestando que o modelo possui um bom ajuste e seu constructo é válido para a realidade brasileira.

Foi realizado então, o segundo passo, a fim de verificar se a teoria estruturada como se encontra é a mais adequada para a realidade do Brasil. No estudo de Perry esta etapa não foi realizada; contudo, optou-se por realizar essa avaliação pelas diferenças culturais existentes entre os dois países focos desta pesquisa. Mesmo que a escala seja válida para a amostra utilizada, ou seja, possa ser utilizada em estudos futuros, ela pode ser melhorada por adaptações na estrutura de sua teoria, o que eleva a relevância de estudos posteriores utilizando a escala de MSP.

O modelo estrutural estimado é recursivo, ou seja, todos os caminhos entre os constructos procedem somente de um constructo preditor (antecedente) para o constructo 
dependente ou resultante (conseqüência). Modelos recursivos na MEE nunca terão menos graus de liberdade do que um modelo de AFC que envolve os mesmos constructos e variáveis (HAIR ET AL., 2006).

De acordo com os mesmo autores, o tamanho da amostra e a identificação também são importantes no MEE e se essas condições tiverem sido satisfeitas no modelo de AFC, então também satisfarão o modelo estrutural. Um modelo estrutural recursivo não pode apresentar um valor de $\mathrm{x}^{2}$ menor do que o obtido pela AFC, na comparação entre os modelos de MEE e AFC considera-se, então, que caso haja um valor menor do primeiro com relação ao segundo, o ajuste geral do modelo estrutural é substancialmente pior do que o do modelo de AFC. O modelo da MEE objetiva explicar relações entre constructos de uma forma mais simples e precisa do que a $\mathrm{AFC}$ e, quando falha, isso se reflete em medidas de ajuste ruins. Em contrapartida, se o modelo estrutural apresentar uma diferença de $\mathrm{x}^{2}\left(\Delta \mathrm{x}^{2}\right)$ muito insignificante em relação ao modelo da AFC, recomenda-se que se faça uma adequação do ajuste estrutural.

Foi testado, então, um modelo estrutural da MSP, considerando o resultado da AFC que apresentou o modelo 1 como o mais adequado (figural 16). 


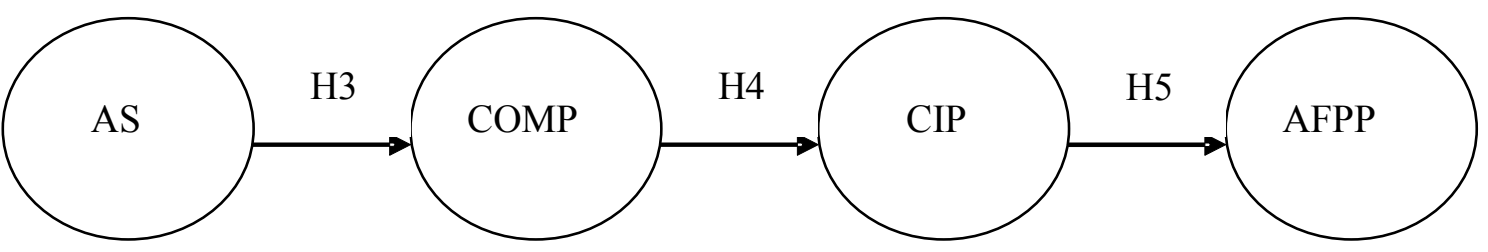

Sendo que:

H3: A dimensão “auto-sacrificio” influencia na dimensão “compaixão”.

H4: A dimensão “compaixão” influencia na dimensão "comprometimento com o interesse público".

H5: A dimensão “comprometimento com o interesse público” influencia na dimensão "atração pela formulação de políticas públicas".

Figura 16. Modelo estrutural esquematizado da MSP e suas respectivas hipóteses

Somente boas medidas de ajuste não são suficientes para atestar se o modelo estrutural é adequado ou não. Há a necessidade de se examinar os parâmetros individuais estimados em relação aos seus respectivos caminhos, sendo que cada caminho representa uma hipótese específica. Cada uma dessas hipóteses foi avaliada como sendo estatisticamente significante e na direção prevista se os parâmetros estimados forem maiores do que zero para uma relação positiva e menor do que zero para uma relação negativa (HAIR ET AL., 2006).

Para o modelo estrutural estimado (figura 17) foram consideradas as mesmas condições de amostra e de identificação do modelo de mensuração, uma vez que elas foram satisfatórias para o modelo de mensuração e conseqüentemente também o são para o modelo estrutural. 


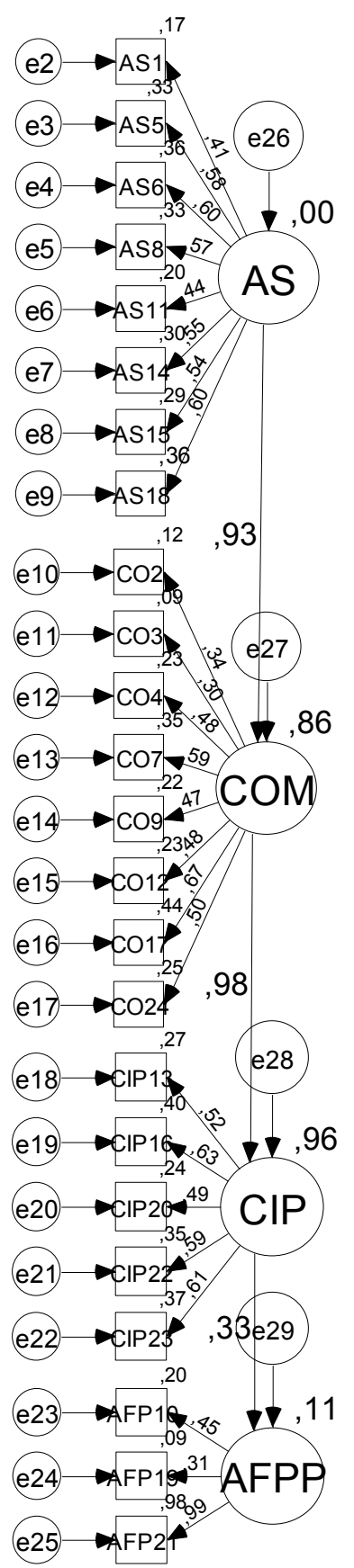

Chi-square $=465,073$

Degrees of freedom $=250$

Probability level $=, 000$

$\mathrm{CFI}=0,808$

RMSEA $=0,067$

$\mathrm{CMIN} / \mathrm{DF}=1,860$

Figural 17. Modelo estrutural estimado 
Este modelo é recursivo, e como tal, apresentou um valor do $x^{2}$ maior do que o valor do $x^{2}$ do modelo de mensuração; as medidas de ajuste geral apresentaram-se muito parecidas com as medidas do modelo da AFC (Tabela 11). Os valores das medidas de ajuste geral resultantes foram: o CFI com um valor de 0,808 , o RMSEA com um valor de 0,67 , o SRMR com um valor de 0,0790 e o normed chi-squared com um valor de 1,860. Todos os valores são admissíveis de acordo com os parâmetros já especificados anteriormente.

Tabela 11 - Resumo dos valores do teste $x^{2}$ e das medidas de ajuste dos modelos da análise fatorial confirmatória e da modelagem de equações estruturais

\begin{tabular}{l|c|c|c|c|c|c|c}
\hline \multicolumn{1}{c|}{ Modelo } & $\mathbf{x}^{\mathbf{2}}$ & $\mathbf{d f}$ & $\mathbf{p}$-value & $\mathbf{C F I}$ & RMSEA & SRMR & CMIN/DF \\
\hline MAFC & 459,793 & 247 &, 000 & .815 & .067 & 0,0781 & 1,842 \\
\hline MMEE & 465,073 & 250 &, 000 & .808 & .067 & 0,0790 & 1,860 \\
\hline$\Delta \mathbf{x}^{2}$ ME-MC & 5,28 & 3 & - & - & - & - & - \\
\hline
\end{tabular}

A diferença de $x^{2}\left(\Delta \mathrm{x}^{2}\right)$ entre os modelos apresentou-se muito pequena, o que segundo Hair et al. (2006) pode indicar que algum ajuste pode ser feito a fim de melhorar o ajuste geral do modelo estrutural. Isso indica que, para a amostra, seria mais adequado que se realizassem outros testes com modelos estruturais alternativos.

Os parâmetros individuais estimados em relação aos seus respectivos caminhos apresentaram-se estatisticamente significativos e na direção prevista, uma vez que são valores maiores do que zero, representando uma relação positiva: H3 = 0,093, H4 =0,98 e H5 = 0,33. 


\section{CAPÍTULO 8 - CONSIDERAÇOES FINAIS}

Foi destacado no início deste trabalho as características do novo cenário da gestão pública que vem se formando no Brasil e da importância que a avaliação e/ou o monitoramento do desempenho vem ganhando como parte indispensável dessa gestão moderna. Foi destacada também a relevância da presente pesquisa para a literatura que trata do PSM - Public Service Motivation, uma vez que os principais estudos da área se concentram nos EUA. Acredita-se que este trabalho servirá de base para o despertar do interesse de pesquisadores com relação a esse constructo e seu instrumento de mensuração; além disso, contribui para pesquisas na área de validação de constructo, uma vez que desenvolve o mesmo por meio de uma ferramenta estatística ainda pouco utilizada em estudos dessa área no Brasil e que é de fundamental importância para o desenvolvimento desse tipo de processo.

O objetivo desta pesquisa foi validar a escala de PSM por meio da validação de constructo. Apesar da afirmativa de Perry e Wise (1990, p. 371) de que "o PSM é positivamente relacionado com o comprometimento organizacional do indivíduo", o mesmo não se confirmou no presente estudo, uma vez que o coeficiente de correlação entre as escalas gerais (constructos) da MSP e do Comprometimento Organizacional não se apresentou significativo, o que abre a discussão para alguns pontos relevantes:

1. A escala de comprometimento de Meyer e Allen (1991) validada por Bastos (1995) pode não ser a mais adequada para medir comprometimento organizacional para a realidade do Brasil, uma vez que vários estudos (PEREIRA; OLIVEIRA, 2000, BREWER; SELDEN, 1998, MORAES, 2005, PERRY; WISE, 1990, ROMZEK, 
1990, LIOU; NYHAN, 1994) confirmam a relação entre os dois constructos correlacionados no presente estudo e que os resultados não apresentaram coeficientes significativos nas escalas gerais.

O modelo de múltiplos componentes de Meyer e Allen (1991) vem sendo amplamente utilizado em estudos da área. No Brasil, várias pesquisas desenvolveramse a partir da validação deste instrumento por Medeiros no ano de 1997 (MEDEIROS, 2003). Apesar da ampla utilização do modelo validado, o autor apontou alguns rumos que a pesquisa nessa área deveria tomar e um deles foi a realização de novos estudos buscando compreender a multidimensionalidade do constructo do comprometimento organizacional. Ele chama a atenção, também, para a validade desse instrumento em diferentes contextos culturais. Assim, o autor propõe uma nova escala em que não utiliza os itens da escala de comprometimento afetivo, alguns itens da escala de comprometimento instrumental e alguns outros da escala de comprometimento normativo. Ele construiu essa nova escala a partir de uma análise fatorial exploratória e confirmatória de outras duas escalas em conjunto.

Esse aspecto deve ser levado em consideração na análise dos coeficientes de correlação encontrados no presente estudo, pois as dimensões que não apresentaram coeficientes de correlação significativos com as dimensões do PSM são justamente as escalas de comprometimento afetivo e instrumental. Isso quer dizer que não é que não exista efetivamente essa relação, mas sim que a escala utilizada para medir a mesma pode não ter sido a mais adequada.

2. Ao analisar os itens que compõem a dimensão do PSM "comprometimento com o interesse público", pode-se verificar que o "tipo" de comprometimento expresso pelas afirmativas difere muito do "tipo" de comprometimento expresso pelas afirmativas das 
escalas de Meyer e Allen. As afirmativas da dimensão do PSM expressam um comprometimento do indivíduo com a comunidade, a sociedade ("eu contribui de maneira não egoísta - generosamente - com minha comunidade’) e com o governo, mas não representado como "organização" e sim como algo simbólico, ou seja, o governo como símbolo de cidadania, de dever civil (“eu considero o serviço público meu dever civil”). Já as afirmativas da escala de comprometimento de Meyer e Allen expressam um comprometimento do indivíduo com a sua organização, com a organização em que trabalha. Esse é o segundo aspecto que deve ser levado em consideração nesta análise;

3. A predominância do comprometimento normativo sobre os outros pode ter sido devido ao nível hierárquico dos respondentes (níveis administrativo e operacional). Esse aspecto pode ter levado a coeficientes de correlação não significativos principalmente da dimensão "atração pela formulação de políticas públicas", e entre as escalas gerais, uma vez que esses funcionários não possuem um contato ou influencia direta na formulação de políticas públicas de seu município;

4. A última consideração é que a correlação de Spearman representa uma relação linear entre duas variáveis. Isso quer dizer que pode haver outras variáveis que se relacionam com o Comprometimento Organizacional que podem interferir na relação deste com a MSP (como por exemplo, o "tipo"de comprometimento citado no item anterior).

Portanto, estatisticamente, a H1: Existe correlação entre os constructos do PSM e do Comprometimento Organizacional não se confirmou; porém, com base nos coeficientes de correlação apresentados e também nos estudos que afirmam existir essa correlação, não se pode rejeitar essa hipótese. Ao contrário, estes resultados devem servir como dados iniciais e 
exploratórios para investigações futuras, a fim de encontrar a escala que represente de forma mais adequada e significativa esta relação.

Posteriormente à etapa descrita acima, foram testadas as outras hipóteses alternativas. Como pôde ser observado nos resultados apresentados, os dois modelos americanos (com quatro e três dimensões) e os dois modelos brasileiros (com quatro e três dimensões) obtiveram índices de ajuste muito semelhantes. A hipótese 2 (H2) de que o PSM é um constructo multidimensional, portanto, é válida, uma vez que o modelo de mensuração estimado demonstra que pode ser explicado pelo conjunto das quatro dimensões latentes que se relacionam. Pode-se concluir, então, que baseado no processo de desenvolvimento da análise estatística e nas medidas de ajuste geral dos modelos que a escala de PSM possui uma boa validade geral de constructo e pode ser utilizada para a amostra utilizada, sendo denominada, a partir deste ponto, como MSP - Motivação no Serviço Público.

Apesar da adequação do instrumento de mensuração da MSP, optou-se, como já citado anteriormente, por avaliar também se a estrutura teórica do constructo também era adequada. As hipóteses H3 (a dimensão “auto-sacrifício” influencia na dimensão “compaixão”), H4 (a dimensão “compaixão" influencia na dimensão “comprometimento com o interesse público”) e H5 (a dimensão “comprometimento com o interesse público" influencia na dimensão “atração pela formulação de políticas públicas”) são válidas, corroborando que a estrutura teórica do modelo também é adequada.

É importante salientar que esse estudo limitou-se por utilizar os mesmos parâmetros utilizados no estudo americano, uma vez que a intenção foi verificar a validade da escala como ela foi construída originalmente. Obviamente que o contexto cultural tem influência neste processo e, sendo assim, são necessários estudos futuros a fim de melhorar as medidas de ajuste geral do modelo como também verificar se há uma estrutura teórica que se ajuste 
melhor à realidade das secretarias pesquisadas. Dessa forma, acredita-se que pode se chegar a um modelo que atenderá de forma mais ampla e mais relevante a mensuração da MSP Motivação no Serviço Público.

Enfim, o propósito deste trabalho foi o de validar a escala de PSM para as secretarias municipais estudadas e, baseado nos resultados apresentados e discutidos, pode-se considerar que a escala é adequada para uso em estudos futuros. Houve uma contribuição relevante cientificamente com a utilização do processo de validação de constructo, uma vez que tanto este quanto os outros tipos de validação são muitas vezes ignorados quando do desenvolvimento/construção de escalas de mensuração. Como não foi identificado o uso da escala pesquisada em estudos brasileiros, acredita-se que este foi um trabalho que contribuiu de forma relevante pra os estudos da área e para o desenvolvimento de pesquisas futuras que deverão ser realizadas a fim de iniciar um trabalho de refinamento não só da escala de MSP, mas também de sua estrutura teórica. 


\section{REFERÊNCIAS}

ADAMS, J. S. Inequity in social exchange. Advances in Experimental social Psychology vol. 2, pp. 267-299, 1965.

ALSTON, L. J., MELO, M., MUELLER, B., PEREIRA, C. Political institutions, policymaking processes and policy outcomes in Brazil. Institute of Behavior Science, research program on environment and behavior, 2005. Disponível em:

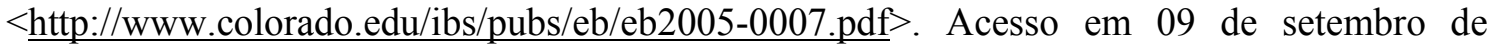
2006.

ANDERSON, D. R., SWEENEY, D. J., WILLIAMS, T. A. Estatística aplicada à Administração e economia. 2a . Ed., São Paulo: Pioneira Thomson Learning, 2002.

ARGYLE, M., GARDNER, G., CIOFFI, F. Supervisory methods related to productivity, absenteeism and labour turnover. Human Relations, v. 11, -. 23-40, 1958. In: VROOM, V. H., DECI, E. L. Management and Motivation. Tennessee: Penguin Books, 1978. Cap. 12: Michael Argyle, Godfrey Gardner and Frank Cioffi: Supervisory methods related to productivity, absenteeism and labour turnover, p.171-91.

ASSEMBLÉIA LEGISLATIVA DO ESTADO DE SÃO PAULO. Reforma do Estado / Assembléia Legislativa do Estado de São Paulo, São Paulo, 1999, 64 p. (Cadernos do Fórum São Paulo Século XXI; c.16). Disponível em < http://www.al.sp.gov.br/web/forum/cadernos/Reforma\%20do\%20Estado.pdf $>$. Acesso em 27 de fevereiro de 2007.

BASTOS, A. V. B. Comprometimento organizacional: de estado da arte a uma possível agenda de pesquisa. Cadernos de Psicologia, n.01, p. 44-63, São Paulo: 1995.

BERGAMNI, C. W. Motivação nas Organizações. 4a . ed. São Paulo: Atlas, 1997.

. Motivação: Mitos, crenças e mal-entendidos. Revista de Administração de Empresas. n. 30, p. 23-34, São Paulo: 1990.

BRASIL, Ministério da Administração Federal e Reforma do Estado. A Nova política de recursos humanos / Ministério da Administração Federal e Reforma do Estado, Brasília: MARE, 1997. 52 p. (Cadernos MARE da reforma do estado; c. 11).

BRAYFIELD, A. H., CROCKETT, W. H. Employee attitudes and employee performance. Psychological Bulletin, v. 52, p. 396-424, 1955. . In: VROOM, V. H., DECI, E. L. Management and Motivation. Tennessee: Penguin Books, 1978. Cap. 5: Arthur H. Brayfield and Walter H. Crockett: Employee attitudes and employee performance, p. 72-82.

BREWER, G. A. Public Service Motivational: theory, evidence, and prospects for research. Annual Meeting of the American Political Science Association, 29 de agosto a 1 de setembro de 2002, Boston, Massachusetts. 
BREWER, G. A., SELDEN, S. C. Whistle Blowers in the Federal Civil Service: New Evidence of the Public Service Ethic. Journal of Administration Research and Theory, 3: p.41-439, 1998.

BREWER, G. A., SELDEN, Sally C., FACER III, Rex L. Individual Conceptions of Public Service Motivation. Public Administration Review, 60, 3, p.254-264, maio/junho, 2000.

BROWN, J. A. C. The social psychology of industry. Penguin Books, 1954. In: VROOM, V. H., DECI, E. L. Management and Motivation. Tennessee: Penguin Books, 1978. Cap. 21: J. A. C. Brown: The social psychology of industry, p. 302-05.

CARMINES, E. G., ZELLER, R. A. Reliability and validity assessment. Sage Publications: USA, 1979.

CENTRAL DE CONCURSOS. Disponível em : < http://www.centraldeconcursos.com.br/noticias/noticias.asp?id noticia=346, $>$ Acessado em 05/05/06.

CERVO, A. L., BERVIAN, P. A. Metodologia Científica. $5^{\text {a }}$ ed., São Paulo: Prentice Hall, 2002.

CONGRESSIONAL BUDGET OFFICE. CBO Memorandum: Comparing federal employee benefits with those in the private sector. Congressional Budget Office, 1998. Disponível em: $<\underline{\text { http://www.cbo.gov/ }}$. Acesso em 01 de setembro de 2006.

CONGRESSIONAL BUDGET OFFICE. Measuring differences between federal and private pay. Congressional Budget Office, 2002. Disponível em: < http://www.cbo.gov/>. Acesso em 01 de setembro de 2006.

COOPER, D. R., SCHINDLER, P. S. Métodos de Pesquisa em Administração. $7^{\mathrm{a}}$ ed., Porto Alegre: Bookman, 2003.

CORTES, L. L. Aspectos que contribuem para a construção do contrato psicológico de indivíduos que ingressam em empresas do setor público. Dissertação (Mestrado em Administração de Empresas) - Departamento de Administração da PUC-Rio, Pontifícia Universidade Católica do Rio de Janeiro, Rio de Janeiro, 2005.

COUTO, C. G. A Longa Constituinte: Reforma do Estado e Fluidez Institucional no Brasil. Dados., Rio de Janeiro, v. 41, n. 1, 1998. Disponível em: $<$ http://www.scielo.br/scielo.php?script=sci_arttext\&pid=S001152581998000100002\&lng=en\&nrm=iso>. Acesso em: 27 Feb 2007.

CREWSON, E. P. Public-Service Motivation: Building Empirical Evidence of Incidence and Effect. Journal of Administration Research and Theory, 4: 499-518, 1997.

CRONBACH, L. J. Fundamentos da testagem psicológica. 5. ed. Porto Alegre: Artes Médicas, 1996.

DENHARDT, R.B, DENHARDT, J.V., The New Public Service: serving rather than steering. Public Administration Review, nov/dec 2000, vol. 60, no. 60. 
DUBRIN, A. J. Fundamentos do Comportamento Organizacional. São Paulo: Pioneira Thomson, 2003.

FIELD, A. Discovering statistics using SPSS. 2a. ed., London, Thousand Oaks, New Delhi: Sage Publications, 2005.

FREDERICKSON, H. G., HART, D. K. The Public Service and the Patriotism of Benevolence, Public Administration Review, Vol. 45, No. 5 (Sep. - Oct., 1985), pp. 547553.

FUHRER, M. C. A., FUHRER, M. R. E. Resumo de Direito Administrativo. $20^{a}$ ed., São Paulo: Malheiros Editora, 2006. 143 p. (Coleção Resumos, 7).

GABRIELLI, J. M. W. Formação do enfermeiro: buracos negros e pontos de luz. Tese (Doutorado em Enfermagem) - Escola de Enfermagem de Ribeirão Preto, Universidade de São Paulo, Ribeirão Preto, 2004.

GEORGE, D., MALLERY, P. SPSS for windows: step by step. 3a. ed., Nedham Heights: Pearson educational company, 2001.

GEORGOPOULOS, B. S., MAHONEY, G. M., JONES, N. W. A path-gal approach to productivity. Journal of applied psychology, v. 41, p. 345-53. In: VROOM, V. H., DECI, E. L. Management and Motivation. Tennessee: Penguin Books, 1978. Cap. 17: Basil Georgopoulos, Gerald M. Mahoney and Nyle W. Jones: A path-gal approach to productivity, p. 237-52.

GUILLEMIN, F., BOMBARDIER, C., BEATON, D. L., Croos-cultural adaptationof healthrelated qualityof live measures: literature review and proposed guidelines. J. Clin. Epidemiol., v. 46, n.12, 1993.

HAIR JR, J. F. et. al., Multivariate analysis. 5 ed. Upper Saddle River: Prentice Hal, 1998.

HAIR, J. F. Jr., BABIN, B., MONEY, A. H., SAMOUEL, P. Fundamentos de métodos de pesquisa em administração. Porto Alegre:Bookman, 2005.

HAIR JR, J. F. et. al., Multivariate analysis. 6 ed. Upper Saddle River: Prentice Hal, 2006.

HERZBERG, F. Work and the nature of man. World Publishing Company, 1966. In: VROOM, V. H., DECI, E. L. Management and Motivation. Tennessee: Penguin Books, 1978. Cap. 7: Frederick Herzberg: The motivation-hygiene theory, p. 86-90.

ISAAC, S., MICHAEL W.B. Handbook in Research and Evaluation: a collection of principles, methods and strategies useful in the planning design and evaluation of studies in educational and the behavioral sciences. California: Edit Publishers, 1971.

KATZ, D. The motivational basis or organizational behaviour. Behavioral Science, v.9, p.131-46, 1964. In: VROOM, V. H., DECI, E. L. Management and Motivation. Tennessee: Penguin Books, 1978. Cap.19: Daniel Katz: The motivational basis or organizational behaviour, p. 265-92. 
KLIKSBERG, B. Hacia un nuevo perfil del Estado en América Latina: los cambios en las percepciones y lãs demandas de la ciudadanía. Revista del CLAD Reforma y Democracia, No. 32, Jun., 2005.

LAWLER III, E. E., PORTER, L. Antecedent attitudes of effective managerial performance. Organizational Behavior and Human Performance, v. 2, p. 122-42, 1967. In: VROOM, V. H., DECI, E. L. Management and Motivation. Tennessee: Penguin Books, 1978. Cap.18: Edward E. Lawler III and Lyman Porter: Antecedent attitudes of effective managerial performance. Organizational Behavior and Human Performance, p. 253-64.

LAWLER II, E. E. Job design and employee motivation. Personnel Pscyhology, v. 22, p. 42635, 1969. In: VROOM, V. H., DECI, E. L. Management and Motivation. Tennessee: Penguin Books, 1978. Cap. 11: Edward E. Lawler II: Job design and employee motivation, p. 161-69.

LAWLER III, W. E. Motivation in work organizations. California: Brooks/Cole Publishing Company, 1973.

LEAVITT, H. J. Unhuman organizations. Harvard Business Review, v.40, p.90-8, 1962. In: VROOM, V. H., DECI, E. L. Management and Motivation. Tennessee: Penguin Books, 1978. Cap.25: Harold J. Leavitt: Unhuman Organizations, p. 337-46.

LEAVITT, H. J. New perspectives in organizational research. Wiley, 1964. In: VROOM, V. H., DECI, E. L. Management and Motivation. Tennessee: Penguin Books, 1978. Cap. 27: Harold J. Leavitt: Applied organization change in industry: structural, technical and human approaches, p. 363-75.

LIKERT, R.. New patterns of management, McGraw-Hill, 1961. In: VROOM, V. H., DECI, E. L. Management and Motivation. Tennessee: Penguin Books, 1978. Cap.23: New patterns of management, p. 320-28.

LINO, M. M. Satisfação profissional entre enfermeiras de UTI: adaptação transcultural do Index of Work Satisfaction (IWS). 236f. Dissertação (Mestrado em Enfermagem) - Escola de Enfermagem, Universidade de São Paulo, São Paulo, 1999.

LIOU, K.T., NYHAN, R. C. Dimensions of organizational commitment in the public sector: an empirical assessment. b, 18:1, p.99-118, 1994.

MAIER, N. R. F., HAYES, J. Creative Management, Wiley, 1962. In: VROOM, V. H., DECI, E. L. Management and Motivation. Tennessee: Penguin Books, 1978. Cap. 24: Norman R. F. Maier and John Hayes: Introducing Creative Management, p. 329-36.

MANN, G. A. A Motive do Serve: Public Service Motivation in Human Resource Management and the role of PSM in the Non-profit Sector. Public Personnel Management, v. 35, n. 1, spring , 2006.

MALHOTRA, N. K., Pesquisa de Marketing: uma orientação aplicada. 4 ed., Porto Alegre: Bookman, 2006. 
MARCH, J. G., SIMON, H. A. Motivational constrains: the decision to participate. Organizations, Wiley, 1958. In: VROOM, V. H., DECI, E. L. Management and Motivation. Tennessee: Penguin Books, 1978. Cap. 9: Jamoes G. March and Herbert A. Simon: Motivational constrains: the decision to participate, p. 107-24.

MASLOW, A. H. A theory of human motivation. Psychological Review, vol. 50, p.370-96, 1943. In: VROOM, V. H., DECI, E. L. Management and Motivation. Tennessee: Penguin Books, 1978. Cap. 2: A. H. Maslow: a theory of human motivation, p. 27-41.

McGREGOR, D. M. The human side of enterprise. Proceedings of the fifth anniversary convocation of the School of Industrial Management $<$ Massachusetts Institute of Technology, p. 23-30, 1957. In: VROOM, V. H., DECI, E. L. Management and Motivation. Tennessee: Penguin Books, 1978. Cap. 22: Douglas M. McGregor: The human side of enterprise, p. 30719.

MAXIMIANO, A. C. A. Teoria Geral da Administração: da revolução urbana 'a revolução digital. 4 ed., São PauloÇ Atlas, 2004.

MEDEIROS, C. A. F. Comprometimento Organizacional: um estudo de suas relações com características organizacionais e desempenho nas empresas hoteleiras. Tese (Doutorado em Administração de Empresas) - Faculdade de Economia, Administração e Contabilidade da Universidade de São Paulo, Universidade de São Paulo, São Paulo, 2003.

MEDEIROS, C. A. F., ENDERS, W. T. Validação do Modelo de Conceitualização de Três Componentes do Comprometimento Organizacional (Meyer e Allen, 1991), Revista de Administração Contemporânea, n. 3, set/dez, 67-87, 1998.

MEYER, J. P., ALLEN, N. J. A Three-component conceptualization of organizational commitment. Human Resource Management Review, v.1, p.61-89, 1991.

MINISTÉRIO DA ADMINISTRAÇÃO FEDERAL E REFORMA DO ESTADO. Plano diretor da reforma do aparelho do estado. Brasil: Presidência da República, 1995.

MORAES, F. M. M. Comprometimento Organizacional e motivação dos professores de uma instituição de ensino superior. 108f. Dissertação Mestrado em Administração) Centro de Educação de Biguaçu, Universidade Vale do Itajaí, Biguaçu, 2005.

MORSE, N. C., WEISS, R. S. The function and meaning of work and the job. In: VROOM, V. H., DECI, E. L. Management and Motivation. Tennessee: Penguin Books, 1978. Cap.3: Nancy C. Morse and Robert S. Weiss: function and meaning of work and the job, p. 42-57.

MOTTA, F. C.P., VASCONCElOS, I. F. G. de. Teoria Geral da Administração. São Paulo: PioneiraThompson Learning, 2004.

NOHARA, I. P. Direito Administrativo. 2a ed. São Paulo: Editora Atlas, 2006. 234p. (Série leituras jurídicas: provas e concursos, vol.2).

NUNNALly, J. C. Psychometric Theory. 2a . ed., Mcgraw-Hill Publishing Company, 1978. 
OPSAHL R. L., DUNNETTE, M. The role of financial compensation in industrial motivation. Psychological Bulletin, v.66, p. 94-118, 1966. In: VROOM, V. H., DECI, E. L. Management and Motivation. Tennessee: Penguin Books, 1978. Cap. 10: Robert L. Opsahl and Marvin Dunnette: The role of financial compensation in industrial motivation, p. 127-59.

PACHECO, R. S. Reformando a administração pública no Brasil: eficiência e accountability democrática. In: Seminário: A Reforma da Administração Pública: possibilidades e obstáculos, 1998, Recife. Disponível em $<$ http://www.fundaj.gov.br/docs/eg/semi4.rtf> Acesso em 01 de setembro de 2006.

PACHECO, R. S. Administração Pública Gerencial: desafios e oportunidades para os municípios brasileiros. Disponível em: http://www.sepam.gov.br/v10/cepam30anos/index2.asp acesso em 03 de setembro de 2006.

PASQUALI, L. Instrumentos psicológicos: manual prático de elaboração. Brasília: LabPAM; IBAPP, 1999.

PEREIRA, J. M. Administração Pública no Brasil: Políticas de Revalorização das Carreiras Típicas de Estado como Fator de Atração de Novos Talentos para o Serviço Público Federal. Revista Observatorio de la Economía Latinoamericana, Universidad de Málaga, España, $\mathrm{n}^{\mathrm{o}}$. 35, 10/12/2004, p. 1-29. disponível em: http://www.eumed.net/cursecon/ecolat/oel35.htm>. Acesso em 03 de setembro de 2006.

PEREIRA, L. C. B. A reforma do aparelho do Estado e a Constituição brasileira. In: Conferência nos seminários sobre a reforma constitucional com os partidos políticos. 1995 . Brasília. Disponível em < http://www.bresserpereira.org.br/papers/1995/98.ReformaAparelhoEstado\&Constituicao.pdf $>$. Acesso em 27 de fevereiro de 2007.

PEREIRA, L. C. B. Reforma da nova gestão pública: agora na agenda da América Latina, no entanto...Revista do Servidor Público, Brasília, n. 1, p.5-26, jan-mar., 2002.

PEREIRA, L. Z., OLIVEIRA, R. C. M. Comprometimento Organizacional: um estudo na área de administração pública municipal. In: ENANPAD, 2000, p.15.

PERRY, J. L.. Measuring Public Service Motivacional: an assessment of construct reliability and validity. Journal of Public Administration Research and Theory, 6, p.5-22, 1996.

PERRY, J. L. Antecedents of Public Service Motivation. Journal of Public Administration Research and Theory, 2, p.181-197, abril, 1997.

PERRY, J. L., WISE, L. R. The motivational bases of public service. Public Administration Review, 50, p.367-373, 1990.

PLANO DIRETOR DA REFORMA DO ESTADO. Disponível em < https://www.planalto.gov.br/publi_04/COLECAO/PLANDI.HTM>. Acesso em $10 \mathrm{de}$ setembro de 2006. 
POLIT, D. H., HUNGLER, B. P. Fundamentos de Pesquisa em Enfermagem. 3. ed., Porto Alegre: Artes Médicas, 1995.

PORTAL DA CIDADE DE RIBEIRÃO PRETO. Disponível em: < http://www.ribeiraopreto.sp.gov.br/index.html>. Acesso em 29 de agosto de 2006.

RAINEY, H. G. Reward Preferences Amogn Public and Private Managers: in search os the service ethic. American Review of Public Administration, vol. 14, n. 4, 288-302, 1982.

RICHARDSON, R.J. Pesquisa Social - Métodos e Técnicas. 3.ed. São Paulo: Atlas, 1999.

ROBBINS, S. P. Comportamento Organizacional. 11a ed., São Paulo: Prentice Hall, 2005.

ROMZEK, B. S. Employee investment and commitment: the ties that bind. Public Administration Review, 50, p.374-381, 1990.

RODRIGUES, R. J. P. Regime jurídico do servidor público nos Estados Unidos. Consultoria Legislativa da Câmara dos Deputados, 1995. Disponível em: < www.pt.org.br/assessor/Universalizacao.doc>. Acesso em 09 de setembro de 2006.

ROSENBERG, M. A lógica da análise do levantamento de dados. São Paulo: Cultrix Editora da Universidade de São Paulo, 1976. 306 p.

ROSS, I. C., ZANDER, A. Need Satisfactions and the employee turnover. Personnel Psychology, v. 10, p. 327-38, 1957. In: VROOM, V. H., DECI, E. L. Management and Motivation. Tennessee: Penguin Books, 1978. Cap 4: Ian C. Ross and Alvin Zander: Need Satisfactions and the employee turnover, p. 61-71.

SANTOS, L. A., CARDOSO, R. L.N. Avaliação de desempenho da ação governamental no Brasil - problemas e perspectivas. In: CONGRESSO INTERNCIONAL DO CLAD SOBRE A REFORMA DO ESTADO E DA ADMINISTRAÇÃO PÚBLICA, VI. 2001. Disponível em:

http://72.14.209.104/search?q=cache:a2T3Rox8SYoJ:pgpe.planejamento.gov.br/Docs/monclad2001.pdf+VI+Co $\underline{\text { ngresso+internacional }+ \text { del }+ \text { CLAD\&hl }=\text { en\&ct }=\text { clnk\&cd }=2>}$. Acesso em 27 de fevereiro de 2007.

SEO, D-C. Development and testing a model that explains contributing factors to unsafe work behavior. 2004. Tese ( Doutorado). Universidade de Indiana- Escola de Saúde, Educação Física e Recreação. Estados Unidos, 2004.

SILVA, J. A. DA, RIBEIRO FILHO, N. P. Avaliação e mensuração de dor: pesquisa, teoria e prática, Ribeirão Preto: Funpec, 2006.

SONI, V. From crisis to opportunity: human resource challenges for the public sector in the twenty-first century. Review of Policy Research, vol. 21, no. 2, 2004

SOUZA, E. C. L., Capacitação Administrativa e Formação de Gestores Governamentais. Revista de Administração Pública, vol. 36, jan-fev, 2002. 
SPILLER, P. T., STEIN, E., TOMMASI, M. Political institutions, policymaking processes and policy outcomes: an intertemporal transactions framework. 2003. Disponível em: < http://burbuja.udesa.edu.ar/departamentos/economia/mariano tommasi/cedi/dts/dt81.pdf

SPITZCOVSKY, C. Direito Administrativo. São Paulo: Editora Damásio de Jesus, 2005.

TANNENBAUM, A. S. Social Psychology of the Work Organization. Wadsworth, 1966. In: VROOM, V. H., DECI, E. L. Management and Motivation. Tennessee: Penguin Books, 1978. Cap. 15: Arnold Tannembaum: The group in organizations, p. 219-26.

THORNDIKE, R. L.; HAGEN, E. P. Measurement and evaluation in pshychology and education. 3 ed. New York: John Wiley, 1969.

TRIST, E. Reviews, abstracts, working groups: XVI International Congresso f applied Psychology, Swets \& Zeitlinger, Amsterdam, p.111-20, 1968. In: VROOM, V. H., DECI, E. L. Management and Motivation. Tennessee: Penguin Books, 1978. Cap. 26: Eric Trist: The professional facilitation change in organizations, p. 349-62.

U.S. OFFICE OF GOVERNMENT ETHICS. Standards of ethical conduct for employee of the executive branch, 2002. Disponível em: $<$ http://www.usoge.gov/index.html $>$. Acesso em 03 de setembro de 2006.

U.S OFFICE OF PERSONNEL MANAGEMENT. Disponível em: < http://www.opm.gov/feddata/html/paystructure/2004/fedPaySystems.asp $>$. Acesso em $01 \mathrm{de}$ setembro de 2006.

VERGARA, S. C. Projetos e Relatórios de Pesquisa em Administração. São Paulo: Atlas, 2004.

VROOM, V. Work and motivation. Wiley, 1964. In: VROOM, V. H., DECI, E. L. Management and Motivation. Tennessee: Penguin Books, 1978. Cap.16: Victor Vroom: The nature of the relationship between motivation and performance, p. 229-36.

VROOM, V. The handbook of social psychology. 2a. ed., Addison-Wesley, 1969. In: VROOM, V. H., DECI, E. L. Management and Motivation. Tennessee: Penguin Books, 1978. Cap. 8: Victor Vroom: Industrial social psychology, p. 91-106.

VROOM, V. H., DECI, E. L. Management and Motivation. Tennessee: Penguin Books, 1978.

WALTZ, C. F., STRICKLAND, O. OL., LENZ, E. R. Measurement in nursing research. 2. ed., Philadelphia: F. A. Davis, 1991.

WEBER, M. A ética protestante e o "espírito" do capitalismo. $3^{\text {a }}$.Ed., São Paulo: Companhia das Letras, 2004.

WITTMER, D. Serving the people or serving for pay: reward preferences among Government, hybrid sector, and business managers. Public Productivity \& Management Review, vol. XIV, n.4, 1991. 
ANEXO - QUESTIONÁRIO 


\section{UNIVERSIDADE DE SÃO PAULO \\ Faculdade de Economia, Administração e Contabilidade de Ribeirão Preto (FEARP)}

Esta pesquisa faz parte de um trabalho de dissertação de mestrado da USP, na área de Recursos Humanos e tem como objetivo estudar a motivação no serviço público. Não há outro vínculo da USP com o órgão pesquisado, a não ser o de objeto de estudo. Portanto, contamos com a sua colaboração no presente estudo.

\section{Os questionários NÃO POSSUEM QUALQUER TIPO DE IDENTIFICAÇÃO DO RESPONDENTE, sendo que as informações contidas nele são estritamente confidenciais.}

Este questionário possui três partes:

\section{INTRUÇÕES PARA PREENCHIMENTO}

- A PARTE I diz respeito a informações sobre o quanto você concorda com as afirmativas feitas sobre suas opiniões PESSOAIS a respeito do serviço público, como participante dele.

- A PARTE II diz respeito a aspectos relacionados ao seu trabalho

- A PARTE III diz respeito a algumas características referentes a você e ao seu trabalho

PARTE I - Em relação a cada ponto, responda à pergunta geral (uma resposta em cada linha) marcando o número que corresponde ao quanto você concorda com a afirmativa, segundo suas opiniões PESSOAIS a respeito do serviço público, como participante dele:
1 - Concordo
2 - Concordo em
3 - Nem concordo
4 - Discordo em
parte
5 - Discordo
nem discordo
totalmente

\begin{tabular}{|c|c|c|c|c|c|}
\hline $\begin{array}{l}\text { PSM } 1 \text { - Fazer a diferença na sociedade representa mais para mim do que realizações } \\
\text { pessoais. }\end{array}$ & 1 & 2 & 3 & 4 & 5 \\
\hline PSM 2 - Frequentemente eu sou motivado pela situação difícil dos desprivilegiados & 1 & 2 & 3 & 4 & 5 \\
\hline PSM 3 - A maioria dos programas sociais é importante demais para se viver sem. & 1 & 2 & 3 & 4 & 5 \\
\hline PSM 4 - É difícil para mim, conter meus sentimentos quando vejo alguém na miséria. & 1 & 2 & 3 & 4 & 5 \\
\hline PSM 5 - Eu acredito em colocar o dever antes de si mesmo. & 1 & 2 & 3 & 4 & 5 \\
\hline $\begin{array}{l}\text { PSM } 6 \text { - Realizar boas ações é definitivamente mais importante do que se dar bem } \\
\text { financeiramente. }\end{array}$ & 1 & 2 & 3 & 4 & 5 \\
\hline PSM 7 - Para mim, patriotismo inclui o cuidado com o bem-estar das outras pessoas. & 1 & 2 & 3 & 4 & 5 \\
\hline PSM 8 - Muito do que eu faço é por uma causa maior do que eu mesmo. & 1 & 2 & 3 & 4 & 5 \\
\hline $\begin{array}{l}\text { PSM } 9 \text { - Eu frequentemente penso no bem-estar das pessoas que eu não conheço } \\
\text { pessoalmente }\end{array}$ & 1 & 2 & 3 & 4 & 5 \\
\hline PSM 10 - Política é uma boa palavra & 1 & 2 & 3 & 4 & 5 \\
\hline PSM 11 - Servir aos cidadãos me faria sentir bem mesmo que eu não fosse pago po & 1 & 2 & 3 & 4 & 5 \\
\hline $\begin{array}{l}\text { PSM } 12 \text { - Eu frequentemente sou lembrado por acontecimentos do cotidiano sobre o quanto } \\
\text { nós dependemos uns dos outros. }\end{array}$ & 1 & 2 & 3 & 4 & 5 \\
\hline $\begin{array}{l}\text { SM } 13 \text { - É fácil para mim me envolver intensivamente nos acontecimentos da minha } \\
\text { omunidade }\end{array}$ & 1 & 2 & 3 & 4 & 5 \\
\hline PSM 14 - Eu acredito que as pessoas devem devolver à sociedade mais do que recebem. & 1 & 2 & 3 & 4 & 5 \\
\hline $\begin{array}{l}\text { PSM } 15 \text { - Eu sou uma daquelas raras pessoas que arriscariam perdas pessoais a fim de } \\
\text { ajudar alguém. }\end{array}$ & 1 & 2 & 3 & 4 & 5 \\
\hline PSM 16 - Eu contribuo de maneira não egoísta (generosamente) com minha comunidade & 1 & 2 & 3 & 4 & 5 \\
\hline $\begin{array}{l}\text { PSM } 17 \text { - Eu tenho muita compaixão por pessoas com necessidades e incapazes de dar o } \\
\text { primeiro passo para ajudarem a si mesmas }\end{array}$ & 1 & 2 & 3 & 4 & 5 \\
\hline PSM 18 - Eu estou preparado para fazer sacrifícios enormes pelo bem da sociedade. & 1 & 2 & 3 & 4 & 5 \\
\hline PSM 19 - A troca (o ato de dar e receber) na formulação de políticas públicas me atrai & 1 & 2 & 3 & 4 & 5 \\
\hline PSM 20 - Um serviço público significativo é muito importante para mim. & 1 & 2 & 3 & 4 & 5 \\
\hline PSM 21 - Eu me importo muito com os políticos & 1 & 2 & 3 & 4 & 5 \\
\hline $\begin{array}{l}\text { PSM } 22 \text { - Eu preferiria ver funcionários públicos fazerem o que é melhor para t } \\
\text { comunidade mesmo que isso afetasse meus interesses pessoais. }\end{array}$ & 1 & 2 & 3 & 4 & 5 \\
\hline PSM 23- Eu considero o serviço público meu dever civil. & 1 & 2 & 3 & 4 & 5 \\
\hline PSM 24 - Há vários programas públicos que eu apoio sin & 1 & 2 & 3 & 4 & 5 \\
\hline
\end{tabular}


PARTE II - A seguir você encontrará uma série de sentenças que procuram descrever o significado de vários aspectos do seu mundo de trabalho. Registre no espaço, o número que corresponde à sua posição frente ao item, utilizando a seguinte escala:

\begin{tabular}{|c|c|c|}
\hline 1 - Discordo totalmente & & 5 - Concordo levemente \\
\hline 2 - Discordo muito & 4 - Não discordo nem concordo & 6 - Concordo muito \\
\hline 3 - Discordo levemente & & 7 - Concordo plenamente \\
\hline
\end{tabular}

\begin{tabular}{|c|c|c|c|c|c|c|c|c|}
\hline 1 & Eu seria muito feliz em dedicar o resto da minha carreira nesta organização. & 1 & 2 & 3 & 4 & 5 & 6 & 7 \\
\hline 2 & $\begin{array}{l}\text { Mesmo se eu quisesse, seria muito difícil para mim deixar minha organização } \\
\text { agora. }\end{array}$ & 1 & 2 & 3 & 4 & 5 & 6 & 7 \\
\hline 3 & $\begin{array}{l}\text { Mesmo se fosse vantagem para mim, eu sinto que não seria certo deixar esta } \\
\text { organização agora. }\end{array}$ & 1 & 2 & 3 & 4 & 5 & 6 & 7 \\
\hline 4 & Eu não sinto um forte senso de integração com esta organização. & 1 & 2 & 3 & 4 & 5 & 6 & 7 \\
\hline 5 & $\begin{array}{l}\text { Se eu decidisse deixar esta organização agora, minha vida ficaria bastante } \\
\text { desestruturada. }\end{array}$ & 1 & 2 & 3 & 4 & 5 & 6 & 7 \\
\hline 6 & Eu me sentiria culpado se deixasse esta organização agora. & 1 & 2 & 3 & 4 & 5 & 6 & 7 \\
\hline 7 & E não me sinto emocionalmente vinculado a esta organização. & 1 & 2 & 3 & 4 & 5 & 6 & 7 \\
\hline 8 & Eu acho que teria poucas alternativas se dixasse esta organização. & 1 & 2 & 3 & 4 & 5 & 6 & 7 \\
\hline 9 & Esta organização merece minha lealdade. & 1 & 2 & 3 & 4 & 5 & 6 & 7 \\
\hline 10 & Eu não me sinto como uma pessoa de casa & 1 & 2 & 3 & 4 & 5 & 6 & 7 \\
\hline 11 & $\begin{array}{l}\text { Se eu já não tivesse dado tanto de mim nesta organização, eu poderia pensar } \\
\text { em trabalhar em outro lugar. }\end{array}$ & 1 & 2 & 3 & 4 & 5 & 6 & 7 \\
\hline 12 & $\begin{array}{l}\text { Eu não deixaria esta organização agora porque eu tenho uma obrigação moral } \\
\text { com as pessoas daqui. }\end{array}$ & 1 & 2 & 3 & 4 & 5 & 6 & 7 \\
\hline 13 & Esta organização tem um imenso siginficado pessoal para mim. & 1 & 2 & 3 & 4 & 5 & 6 & 7 \\
\hline 14 & $\begin{array}{l}\text { Uma das poucas consequencias negativas de deixar esta organização seria a } \\
\text { escassez de alternativas imediatas. }\end{array}$ & 1 & 2 & 3 & 4 & 5 & 6 & 7 \\
\hline 15 & Eu devo muito a esta organização. & 1 & 2 & 3 & 4 & 5 & 6 & 7 \\
\hline 16 & $\begin{array}{l}\text { Na situação atual, ficar com nesta organização é na relidade uma necessidade } \\
\text { mais do que um desejo. }\end{array}$ & 1 & 2 & 3 & 4 & 5 & 6 & 7 \\
\hline 17 & Eu não sinto nenhuma obrigação em permanecer na nesta organização. & 1 & 2 & 3 & 4 & 5 & 6 & 7 \\
\hline 18 & Eu realmente sinto os problemas da organização como se fossem meus. & 1 & 2 & 3 & 4 & 5 & 6 & 7 \\
\hline
\end{tabular}

PARTE III - Esta parte deve ser preenchida marcando a opcão que corresponde à sua resposta.

1-Sexo: ( ) Feminino ( ) Masculino

2 - Qual a sua idade? anos

3 - Estado civil: ( ) Solteiro ( ) Casado ( ) Separado/Divorciado ( ) viúvo

4 - Grau de escolaridade:

( ) Primeiro grau completo ( ) Primeiro grau incompleto ( ) Segundo grau completo

( ) Segundo grau incompleto ( ) Superior completo ( ) Superior incompleto ( ) Pós-Graduação

5 - Qual é a sua renda mensal bruta familiar (sem descontos)? (em reais $R \$$ )

( ) até $700(\quad)$ de $701-1.700(\quad)$ de 1.701-2.700 ( ) de 2.701 a $3.700(\quad)$ acima de 3.701

6 - Há quanto tempo você trabalha no serviço público? anos

7 - Com relação a seu vínculo com o serviço público, você é:

( ) servidor efetivo/concursado ( ) servidor temporário ou comissionado

\section{Obrigado pela sua colaboração!}

